\title{
Schoolverlaters tussen onderwijs en arbeidsmarkt 1995
}

Citation for published version (APA):

van Smoorenburg, M. S. M., \& Willems, E. (1996). Schoolverlaters tussen onderwijs en arbeidsmarkt 1995. Researchcentrum voor Onderwijs en Arbeidsmarkt, Faculteit der Economische Wetenschappen. ROA Reports No. 3 https://doi.org/10.26481/umarep.1996003

Document status and date:

Published: 01/01/1996

DOI:

10.26481/umarep.1996003

Document Version:

Publisher's PDF, also known as Version of record

\section{Please check the document version of this publication:}

- A submitted manuscript is the version of the article upon submission and before peer-review. There can be important differences between the submitted version and the official published version of record.

People interested in the research are advised to contact the author for the final version of the publication, or visit the DOI to the publisher's website.

- The final author version and the galley proof are versions of the publication after peer review.

- The final published version features the final layout of the paper including the volume, issue and page numbers.

Link to publication

\footnotetext{
General rights rights.

- You may freely distribute the URL identifying the publication in the public portal. please follow below link for the End User Agreement:

www.umlib.nl/taverne-license

Take down policy

If you believe that this document breaches copyright please contact us at:

repository@maastrichtuniversity.nl

providing details and we will investigate your claim.
}

Copyright and moral rights for the publications made accessible in the public portal are retained by the authors and/or other copyright owners and it is a condition of accessing publications that users recognise and abide by the legal requirements associated with these

- Users may download and print one copy of any publication from the public portal for the purpose of private study or research.

- You may not further distribute the material or use it for any profit-making activity or commercial gain

If the publication is distributed under the terms of Article $25 \mathrm{fa}$ of the Dutch Copyright Act, indicated by the "Taverne" license above, 


\section{Schoolverlaters tussen onderwijs en arbeidsmarkt 1995}

ROA-R-1996/3

M.S.M. van Smoorenburg

E.J.T.A. Willems

Researchcentrum voor Onderwijs en Arbeidsmarkt

Faculteit der Economische Wetenschappen en Bedrijfskunde Rijksuniversiteit Limburg

Maastricht, mei 1996 
ISBN 90-5321-172-1 


\section{Inhoudsopgave}

Voorwoord I

Samenvatting $\quad$ V

1 Bestemming en arbeidsmarktpositie in vogelvlucht

1.1 Bestemming van schoolverlaters $\quad 1$

$\begin{array}{ll}\text { 1.2 Schoolverlaters op de arbeidsmarkt } & 2\end{array}$

1.3 Vrouwen en allochtonen op de arbeidsmarkt 8

1.4 Resumé 9

2 Bestemming van schoolverlaters $\quad 11$

3 Doorstroom naar vervolgonderwijs

$\begin{array}{lr}3.1 \text { Stromen in het onderwijs } & 19\end{array}$

$\begin{array}{ll}3.2 \text { De keuze voor vervolgonderwijs } & 20\end{array}$

$\begin{array}{ll}3.3 \text { Resumé } & 27\end{array}$

$4 \quad$ Intrede op de arbeidsmarkt

4.1 Het aanbieden op de arbeidsmarkt $\quad 29$

$\begin{array}{ll}4.2 \text { Werkloosheid } & 30\end{array}$

4.3 Beloning en benutting $\quad 35$

$\begin{array}{ll}4.4 \text { Resumé } & 37\end{array}$

5 De marktpositie van opleidingen 39

6 De flexibilisering van de arbeidsmarkt

6.1 Inleiding $\quad 45$

$\begin{array}{ll}\text { 6.2 Flexibele arbeidsrelatie } & 46\end{array}$

6.3 Part-time werk $\quad 53$

6.4 Mobiliteit bij intrede op de arbeidsmarkt $\quad 56$

6.5 Resumé $\quad 59$

$7 \quad$ Additionele training

$\begin{array}{ll}7.1 \text { Inleiding } & 61\end{array}$

$\begin{array}{ll}7.2 \text { Training van werklozen } & 61\end{array}$

7.3 Training van werkenden $\quad 63$

$\begin{array}{ll}7.4 \text { Resumé } & 73\end{array}$

$\begin{array}{ll}\text { Enkele centrale begrippen } & 75\end{array}$ 



\section{Voorwoord}

De positie die schoolverlaters op de arbeidsmarkt weten te verwerven neemt een steeds belangrijkere plaats op de maatschappelijke agenda in. Daarbij gaat het onder meer om vragen als 'Slagen schoolverlaters erin om (snel) een baan te vinden?' en 'Vinden schoolverlaters een baan die past bij hun opleidingsniveau?'. Dit rapport geeft op deze vragen een antwoord. Daarnaast wordt stilgestaan bij de doorstroom van schoolverlaters naar vervolgonderwijs, of het nou gaat om voltijd opleidingen, combinaties van leren en werken of het volgen van een beroepsgerichte aanvullende cursus.

Schoolverlaters tussen onderwijs en arbeidsmarkt 1995 is vrijwel volledig gebaseerd op de enquête Registratie van Uitstroom en Bestemming van Schoolverlaters (RUBS) die in het voorjaar van 1995 is gehouden onder schoolverlaters van het schooljaar 1993/'94 van het Algemeen Voortgezet Onderwijs (AVO), het Voorbereidend Beroepsonderwijs (VBO) en de korte, tussen en lange variant van het Middelbaar Beroepsonderwijs (MBO). Deze rapportage is daarmee de opvolger van de RUBS-rapportages die vanaf 1993 door het LDC zijn uitgegeven. Het RUBS-project wordt, behalve door de deelnemende scholen, financieel mogelijk gemaakt door het Ministerie van Onderwijs, Cultuur en Wetenschappen, het Landelijk Dienstverlenend Centrum voor Studie- en Beroepskeuzevoorlichting (LDC) en het Ministerie van Landbouw, Natuurbeheer en Visserij.

Dit rapport richt zich met name op degenen die zich in beleidsmatige zin bezighouden met de arbeidsmarktpositie van schoolverlaters. In het bijzonder kunnen daarbij worden genoemd de Ministeries van Onderwijs, Cultuur en Wetenschappen, Sociale Zaken en Werkgelegenheid en Landbouw, Natuurbeheer en Visserij, Arbeidsvoorziening, sociale partners en het (georganiseerde) onderwijsveld. Daarnaast brengt het LDC vertrouwelijke rapportages uit met gegevens over individuele scholen. Tevens worden de gegevens gebruikt voor LDC-publikaties, gericht op de intermediairs bij de studie- en beroepskeuzevoorlichting.

De gegevens in dit rapport hebben een terugblikkend karakter. Er vindt een analyse plaats van de eerste ervaringen van schoolverlaters op de arbeidsmarkt en in het vervolgonderwijs. Dit betekent dat niet of nauwelijks wordt ingegaan op de verwachte toekomstige arbeidsmarktontwikkelingen. Dergelijke prognoses zijn recentelijk door het ROA gepubliceerd in het rapport De arbeidsmarkt naar opleiding en beroep tot 2000.

Met ingang van de jaargang 1996 zullen er op het gebied van het schoolverlatersonderzoek enkele belangrijke wijzigingen worden doorgevoerd. In de eerste plaats zal het RUBS-project, met name voor het AVO en het VBO, worden afgestemd op het Schoolverlatersvolgsysteem dat door de Nederlandse Vereniging van Schooldekanen is ontwikkeld. Hierdoor wordt een beter zicht verkregen op de doorstroom van schoolverlaters naar het vervolgonderwijs en de problemen die zich hierbij eventueel voordoen. Een pilot-project met betrekking tot deze integratie van RUBS met het Schoolverlatersvolgsysteem wordt begin 1996 afgesloten. 


\section{Samenvatting}

\section{Doorstroom naar vervolgonderwijs}

Van de schoolverlaters van het AVO gaat meer dan 90\% verder leren, met name in een nieuwe voltijd opleiding: de doorstroom naar het leerlingwezen bedraagt slechts $2 \%$. Bij het VBO neemt de doorstroom naar het leerlingwezen wel iets toe. Nog meer dan in afgelopen jaren betreft dit opleidingen in de technische richting. Schoolverlaters van de korte $\mathrm{MBO}$-opleiding kiezen in vergelijking met vorig jaar vaker voor een voltijd vervolgopleiding: 36\% stroomt hier naar door. Daarnaast is het opmerkelijk dat allochtone schoolverlaters minder vaak doorstromen naar het leerlingwezen, maar juist relatief vaak een nieuwe voltijd opleiding gaan volgen.

De meest opvallende tendens in het doorstroomgedrag betreft echter de aanzienlijk grotere belangstelling voor het HBO. Niet alleen HAVO- en MBO-schoolverlaters kiezen vaker voor een $\mathrm{HBO}$-opleiding, maar ook VWO-schoolverlaters blijken vaker voor een dergelijke opleiding te kiezen. Daarbij geldt dat vooral de meisjes van het VWO verhoudingsgewijs vaak naar het HBO gaan en dus minder vaak doorstromen in een universitaire studierichting.

\section{Intrede op de arbeidsmarkt}

De werkloosheid onder schoolverlaters is het afgelopen jaar iets gedaald: van gemiddeld $8 \%$ naar $7 \%$. Vooral onder schoolverlaters van het kort $\mathrm{MBO}$ - en daarbinnen met name de richting economie - is de werkloosheid hoog. Ook schoolverlaters van het VBO economie en het HAVO hebben veel moeite om een baan te vinden. Tevens geldt dat allochtonen veel vaker werkloos zijn dan schoolverlaters met een Nederlandse achtergrond.

De kwaliteit van het werk is voor schoolverlaters van het $\mathrm{MBO}$ in het algemeen goed te noemen. Schoolverlaters van het AVO komen nogal eens in kwalitatief slechte banen terecht. Hetzelfde geldt voor schoolverlaters van het VBO landbouw, VBO economie en het MBO-kort economie. Schoolverlaters met een technische achtergrond bereiken daarentegen in het algemeen kwalitatief goede banen. Wel kunnen technisch opgeleiden bij arbeidsmarktintrede slechts in beperkte mate uitwijken naar andere beroepen en sectoren. Bovendien is de werkgelegenheid in deze sectoren erg conjuncturgevoelig.

\section{De flexibilisering van de arbeidsmarkt}

De laatste tijd is er een toenemende roep om flexibilisering van de arbeidsmarkt. Toch is het percentage flexwerkers (o.a. uitzendkrachten, werkenden op basis van oproepof nul-urencontract, werkenden met een tijdelijke aanstelling) de afgelopen jaren nauwelijks toegenomen. Ongeveer een kwart van de schoolverlaters is werkzaam op basis van een flexibele arbeidsrelatie. Daaronder bevinden zich opvallend genoeg relatief 
weinig vrouwen, maar juist veel allochtonen. Vrouwen en allochtonen zijn daarnaast vaker in deeltijd werkzaam.

De flexibiliteit van de arbeidsmarkt komt vanzelfsprekend niet alleen tot uitdrukking in de aard of de duur van het dienstverband, maar ook in de mate waarin arbeidskrachten van baan veranderen. Opvallend is dat een derde van de schoolverlaters binnen een jaar meer dan één baan heeft gehad. Daarnaast is ongeveer een vijfde op zoek naar een andere baan. Dit betreft dan vooral schoolverlaters met een flexibel arbeidscontract en schoolverlaters waarvoor de baan qua niveau en/of richting niet goed aansluit bij de gevolgde opleiding.

\section{Additionele training}

De deelname van schoolverlaters aan additionele training is de laatste jaren gestaag afgenomen. Dit geldt voor zowel werkloze als werkende schoolverlaters. Daarbij geldt dat werklozen minder vaak en minder langdurige cursussen volgen, ofschoon ook zo'n driekwart van de werklozen cursussen van 4 maanden of langer heeft gevolgd. Schoolverlaters volgen vooral cursussen op het terrein van juridische zaken, belastingen, verzekeringen, bankzaken e.d. In vergelijking met de rest van de beroepsbevolking volgen zij relatief weinig automatiserings- of computercursussen.

Opvallend is dat vooral degenen die deficieten in de gevolgde opleiding ervaren doordat zij werk op een hoger niveau of in een andere vakrichting hebben aanvaard relatief vaak additionele training volgen. Schoolverlaters met een flexibele arbeidsrelatie volgen veel minder vaak cursussen dan degenen met een 'normaal' dienstverband. Tussen enerzijds mannen en vrouwen en anderzijds autochtonen en allochtonen zijn er wat dit betreft nauwelijks verschillen. 


\section{Bestemming en arbeidsmarktpositie in vogelvlucht}

\subsection{Bestemming van schoolverlaters}

Tegen het eind van hun opleiding moeten scholieren en studenten een keuze maken over hetgeen zij daarna willen doen. Daarbij gaat het doorgaans om de keuze tussen een voltijd vervolgopleiding, een combinatie van leren en werken in het leerlingwezen of in-service onderwijs of voltijd werken. Hoe de afweging tussen deze alternatieven uitpakt, hangt sterk samen met het opleidingsniveau dat is bereikt, ofschoon er ook duidelijke verschillen tussen de onderscheiden opleidingsrichtingen zijn. Figuur 1.1 laat per schooltype de bestemming van de schoolverlaters van het schooljaar 1993/94 zien.

Figuur 1.1

Bestemming van schoolverlaters per schooltype, 1995

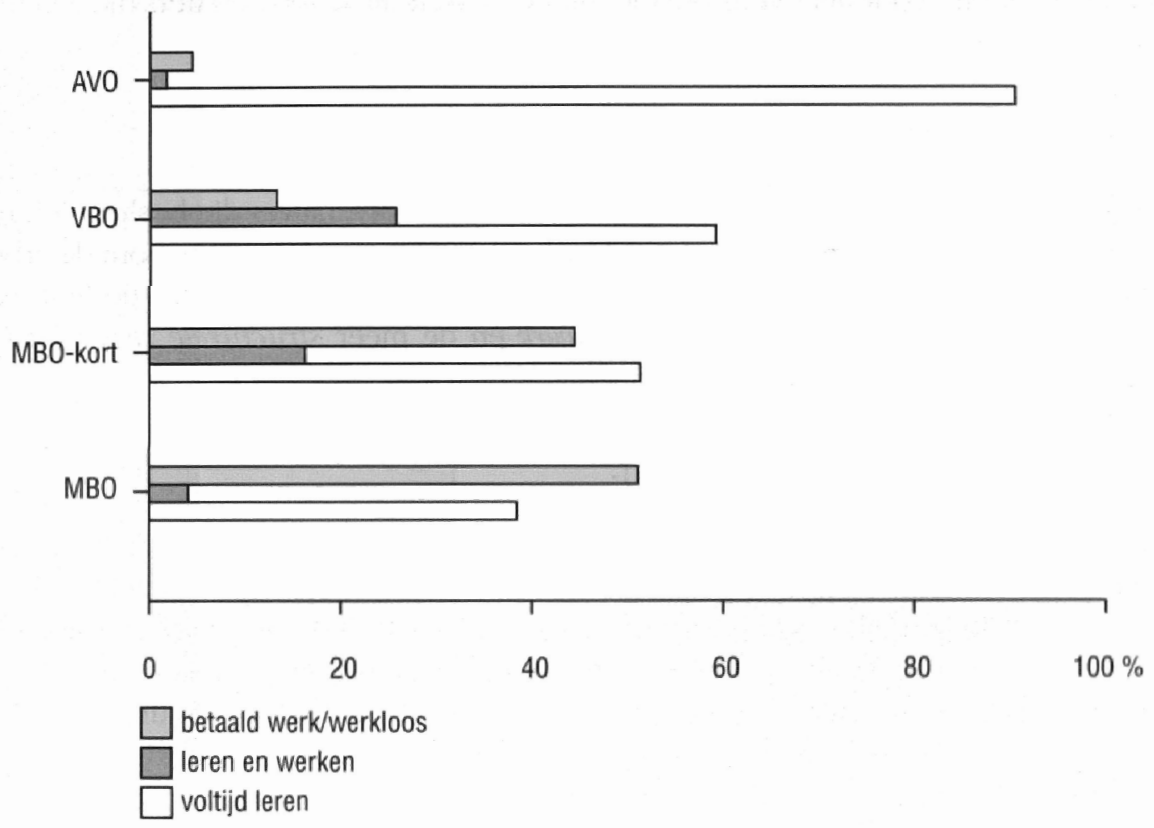

Het AVO is geen eindonderwijs: ruim 90\% van de schoolverlaters kiest er dan ook voor om na het verlaten van deze opleiding nog een volledige dagopleiding te gaan volgen. Slechts enkelen bieden zich met hun MAVO-, HAVO- of VWO-diploma aan op de arbeidsmarkt of kiezen voor een combinatie van werken en leren. Vergelijking met resultaten van voorgaande jaren laat bovendien zien dat er wat dit betreft nauwelijks iets verandert.

Ofschoon het VBO officieel slechts voorbereidt op een 'echte' beroepsopleiding, besluit 
toch ruim $10 \%$ van de schoolverlaters om direct na afloop van deze opleiding te gaan werken. Ruim een kwart gaat een opleiding in het (primair) leerlingwezen of een in-service opleiding verpleging of verzorging volgen. Evenals in voorgaande jaren gaat meer dan de helft van de VBO-schoolverlaters voltijd verder leren in MBO of kort MBO.

Van de KMBO-schoolverlaters gaat ruim een derde na deze opleiding nog een voltijd opleiding volgen, veelal een lange $\mathrm{MBO}$-opleiding, al dan niet met een verkort programma. Dit is een lichte toename ten opzichte van de afgelopen jaren. De belangstelling voor het duaal onderwijs neemt daarentegen iets af. Circa 15\% van de schoolverlaters kiest voor een dergelijke optie van werken en leren. Ruim 40\% van de KMBO'ers biedt zich met dit diploma aan op de arbeidsmarkt, een verhoudingsgewijs groot deel overigens zonder succes.

Van de MBO-schoolverlaters wil ruim de helft na het verlaten van de opleiding gaan werken, een lichte toename ten opzichte van voorgaande jaren. Daar staat tegenover dat bijna $40 \%$ er voor kiest om na afloop van het $\mathrm{MBO}$ nog een volledige dagopleiding te gaan volgen, met name in het HBO. Dit percentage wijkt niet of nauwelijks af van eerdere jaren. De figuur laat verder zien dat $4 \%$ van de MBO'ers doorstroomt naar een duale opleiding. Voor het overgrote merendeel betreft dit schoolverlaters die een in-service opleiding in de verpleging of verzorging gaan volgen.

\subsection{Schoolverlaters op de arbeidsmarkt}

Deze paragraaf gaat in op de minderheid van de schoolverlaters die besluit zich na de afgesloten opleiding aan te bieden op de arbeidsmarkt. Daarbij gaat het om de arbeidsmarktpositie in brede zin. Hierbij wordt een onderscheid gemaakt tussen de kans op bet vinden van werk, de kwaliteit van het werk en de meer structurele risicopositie die schoolverlaters op de arbeidsmarkt innemen ${ }^{2}$.

\section{Kans op het vinden van werk}

Vaak wordt de arbeidsmarktpositie van schoolverlaters van een bepaalde opleiding afgemeten aan éen enkel kengetal: het werkloosheidspercentage. Vanzelfsprekend is dit een zeer belangrijke indicator, maar zelfs wat betreft de kans op werk is uitsluitend het werkloosheidspercentage een beperkt begrip. Het gaat er immers ook om in welk tijdsbestek schoolverlaters een baan weten te vinden. Daarom is in figuur 1.2 niet alleen het werkloosheidspercentage gepresenteerd, maar ook de duur van de intredewerkloosheid". Dit laatste is het aantal maanden dat men in totaal werkloos is geweest sinds het verlaten van de opleiding.

2 Dit in navolging van R.K.W. van der Velden en M.H. Wieling, De arbeidsmarktkansen per opleiding, in: H. Scholten en S.C. de Groot (red.). Arbeidsmarkt en Sociale Zekerbeid. Beleid in Beweging, IVA. Tilburg, blz. 106-114, 1994 en M.S.M. van Smoorenburg en R.K.W. van der velden, Schoolverlaters op de arbeidsmarkt, de uitstroom en bestemming van bet schooljaar 1992-1993, LDC, Leeuwarden, 1995.

3 Dit begrip moet niet worken verward met het begrip baanzoekduur', zoals dat onlangs onder ande$\mathrm{re}$ is geoperationaliseed door Borghans en Willems. Baanzoekduur van HBOers onder de loep. Tijdschrift loor Arbeidstraagstukken, jrg. 11, nr. 4, 1995, blz. 348-357. 
De werkloosheid onder schoolverlaters is in 1995 iets afgenomen in vergelijking met het jaar ervoor. Deze daling doet zich bij alle schooltypen voor, behalve bij het kort MBO, waar de werkloosheid juist iets is gestegen. De werkloosheid is echter nog niet terug op het lage niveau van 1993. Ook de gemiddelde duur van de intredewerkloosheid is nu hoger dan twee jaar geleden. De schoolverlaters van 1993/'94 deden er gemiddeld bijna 1,5 maand over om een baan te vinden.

Figuur 1.2

Werkloosheidspercentage en gemiddelde intredewerkloosheid van schoolverlaters per schooltype, 1993-1995
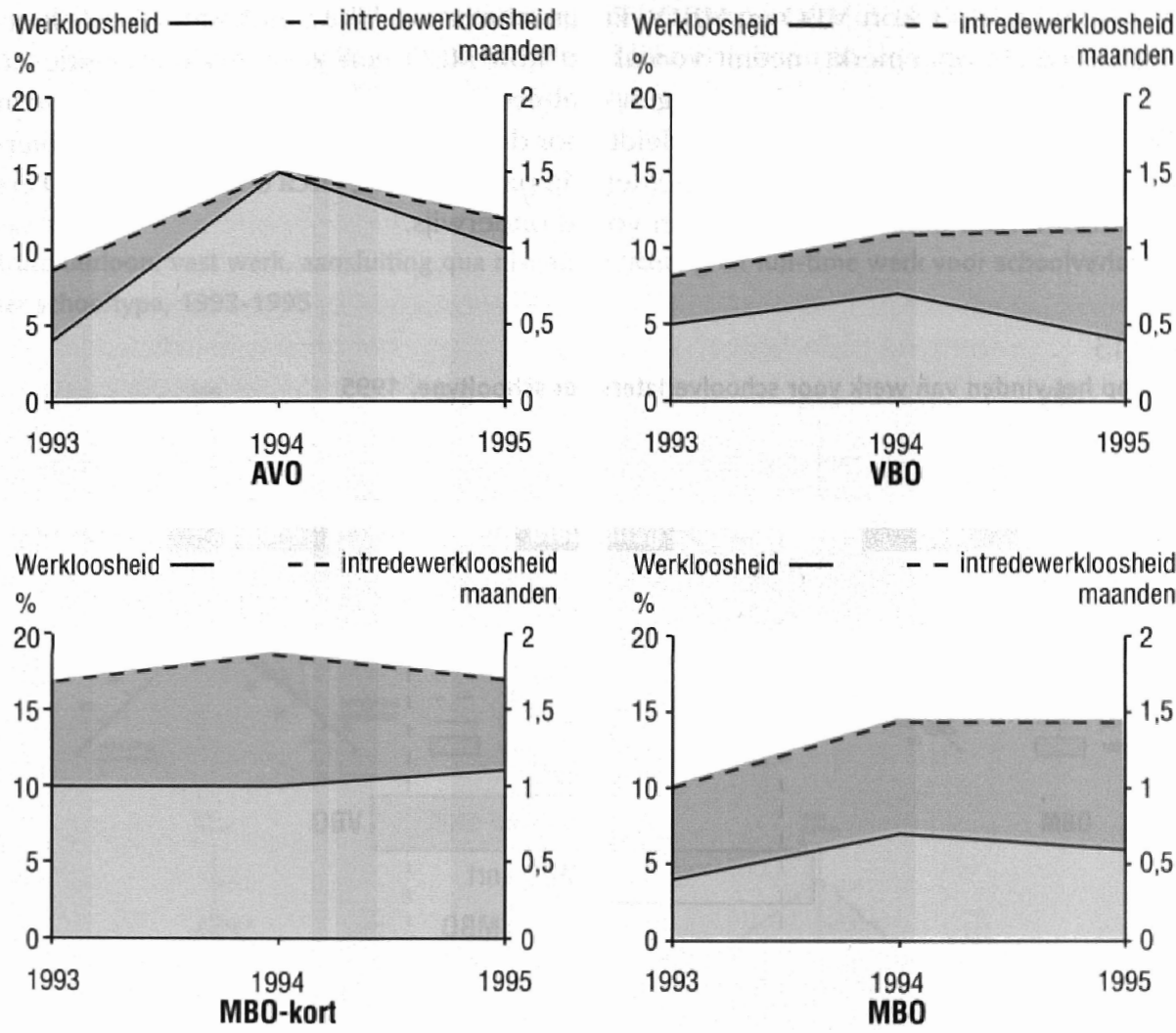

Tussen 1993 en 1994 is zowel het werkloosheidspercentage als de intredewerkloosheid van AVO-schoolverlaters fors toegenomen. Deze stijging is het afgelopen jaar maar slechts ten dele teniet gedaan. De werkloosheid blifft met $10 \%$ zelfs op een hoog niveau liggen. Bij het $\mathrm{VBO}$ is er daarentegen wel sprake van een volledig herstel. De werkloosheid ligt zelfs onder het niveau van 1993. Opvallend is echter dat VBO'ers er wel steeds langer over doen om een betaalde baan te vinden. 
Een ronduit zwakke arbeidsmarktpositie wat betreft de kans op werk wordt ingenomen door de schoolverlaters van het kort MBO. Het werkloosheidspercentage is het hoogst van alle onderscheiden schooltypen, terwijl KMBO'ers ook duidelijk de meeste moeite hebben om een baan te verwerven, blijkend uit een gemiddelde duur van de intredewerkloosheid van bijna 2 maanden. Overigens is deze duur wel iets afgenomen ten opzichte van het jaar ervoor. Wellicht zijn dit de eerste zwakke tekenen van herstel. MBO'ers komen vrij snel aan werk, ofschoon men doorgaans toch iets meer tijd nodig heeft dan AVO'ers en VBO'ers. De werkloosheid blijft eveneens verhoudingsgewijs laag.

Figuur 1.3 vat de relatieve kans op werk voor de schoolverlaters van de vier onderscheiden schooltypen nog eens in één oogopslag samen. Daarbij wordt de positie van de afzonderlijke schooltypen gerelateerd aan het gemiddelde van alle opleidingsclusters van $\mathrm{AVO}, \mathrm{VBO}$, kort $\mathrm{MBO}$ en $\mathrm{MBO}^{4}$. Er zijn twee duidelijke uitschieters. Zoals hierboven reeds is opgemerkt, neemt vooral het kort $\mathrm{MBO}$ een zeer zwakke positie in. VBO-schoolverlaters vinden daarentegen snel een baan, dit ondanks het feit dat een VBO-opleiding eigenlijk niet direct opleidt voor de arbeidsmarkt. Overigens moet hierbij ook worden bedacht dat, zoals opgemerkt in paragraaf 1.1 , circa $60 \%$ van de VBO'ers doorstroomt naar een andere vorm van voltijd onderwijs.

\section{Figuur 1.3}

\section{Kans op het vinden van werk voor schoolverlaters per schooltype, 1995}

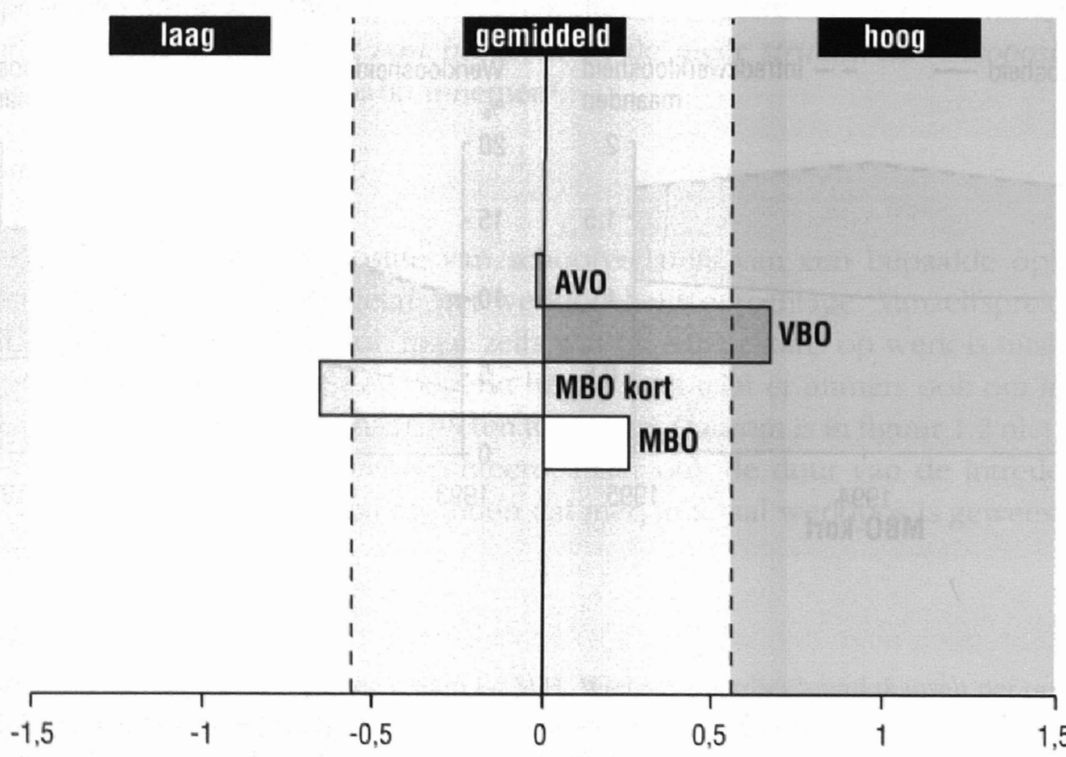

4 Zie voor een verdere toelichting op de berekeningswijze M. van Smoorenburg en E. Willems, Metbodiek RLBS-enquête 1995, ROA-werkdocument, te verschijnen. 


\section{Kwaliteit van het werk}

Niet alleen het snel vinden van werk telt, maar ook de aard van dit werk is natuurlijk belangrijk. Daarbij gaat het om onder meer de beloning, het niveau van het werk en de aard van de werkzaamheden en de mate waarin dit werk zekerheid biedt in de vorm van een full-time en/of vast dienstverband. Deze vijf kengetallen zijn per schooltype voor de afgelopen drie jaar samengevat in figuur 1.4. Het oranjegekleurde gebied geeft daarbij de situatie voor 1995 weer.

Schoolverlaters van het MBO weten in het algemeen een erg goede kwaliteit van het werk te bewerkstelligen. Dit blijkt vooral uit de fors hogere beloning voor MBO-schoolverlaters'. Ook weten MBO'ers vaker een vaste baan te verwerven en werken zij veel vaker op full-time basis. Wel is ruim een derde van de MBO-schoolverlaters werkzaam op een te laag niveau. Dit is vergelijkbaar met het percentage in 1994, maar fors hoger dan in 1993. Ruim de helft van de MBO'ers blijkt een baan in de eigen vakrichting te verwerven, meer dan bij alle andere schooltypen.

Figuur 1.4

Bruto uurloon, vast werk, aansluiting qua niveau en richting en full-time werk voor schoolverlaters per schooltype, 1993-1995
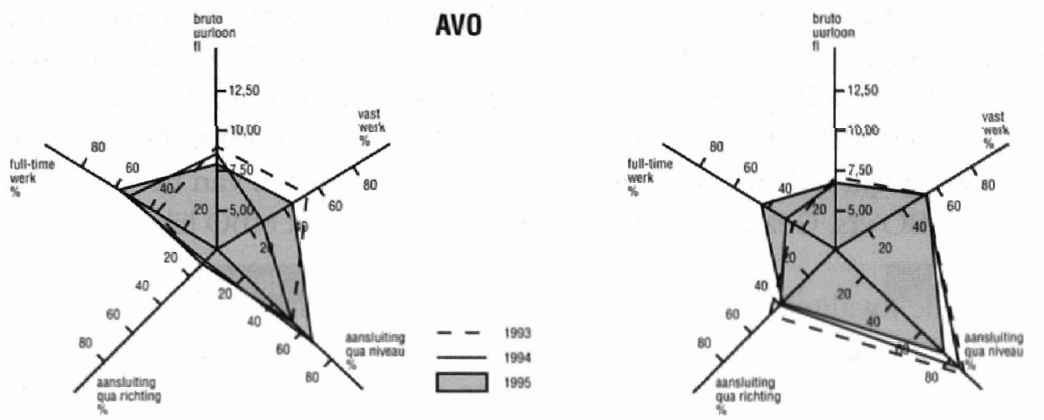

VBO
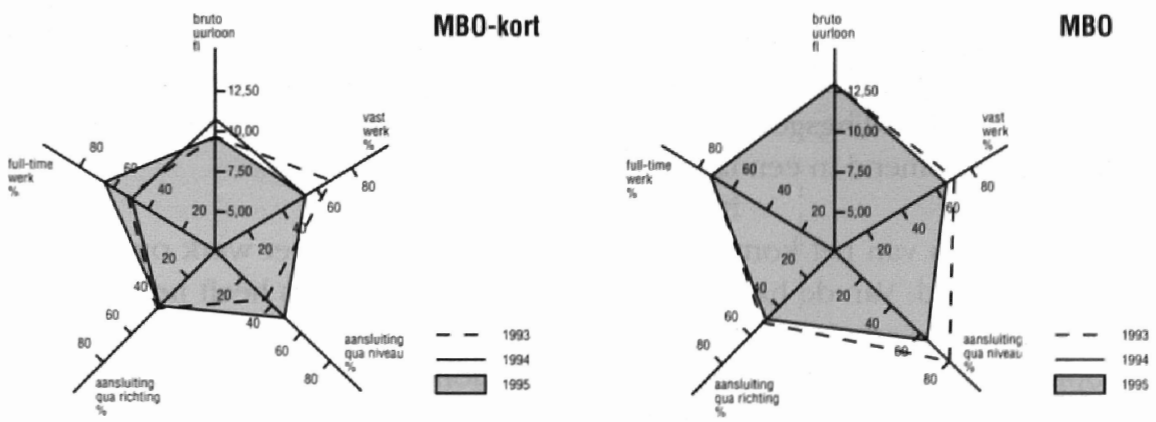

5 Overigens moet daarbij wel worden bedacht dat MBO'ers gemiddeld ook ouder zijn wanneer zij de arbeidsmarkt betreden. 
AVO-schoolverlaters moeten het vaak stellen met een relatief lage beloning. De daling van het gemiddelde bruto uurloon, die al langer aan de gang is, zet zich in 1995 versterkt door. Wel hebben weer wat meer schoolverlaters van het AVO een vaste baan verworven en is het percentage AVO'ers dat een baan beneden hun niveau heeft geaccepteerd iets afgenomen. Daarnaast vinden AVO-schoolverlaters steeds vaker full-time werk. VBO-schoolverlaters hebben met name een wat betere positie wat betreft de benutting van hun opgedane kwalificaties. Slechts een beperkt deel is onder VBOniveau werkzaam, een percentage dat overigens wel langzaam maar gestaag toeneemt. Ongeveer de helft van de VBO'ers heeft binnen een jaar een vaste aanstelling. Ondanks de veel gehoorde roep om flexibilisering van de arbeidsmarkt is dat een percentage dat de afgelopen jaren, net als overigens voor de andere opleidingsniveaus, niet of nauwelijks is veranderd ${ }^{6}$. Wel werken veel VBO'ers in deeltijd, ofschoon hier het afgelopen jaar een duidelijke afname kan worden geconstateerd. De schoolverlaters van het VBO komen er wat betreft de beloning relatief slecht vanaf. Voor een deel kan dit echter worden verklaard door het feit dat VBO'ers verhoudingsgewijs vaak werkzaam zijn in een leer-arbeids-overeenkomst, waarbij een gedeelte van de beloning tot uitdrukking komt in de mogelijkheid tot het opdoen van extra kennis en ervaring. Daarnaast zijn VBO'ers relatief jong wanneer ze de arbeidsmarkt betreden.

Hiervoor is reeds geconstateerd dat schoolverlaters van het kort MBO de meeste moeite hebben om een baan te vinden. Figuur 1.4 laat voorts zien dat voor één van de twee KMBO'ers die wel een baan hebben dit een baan onder het niveau betreft, zodat kan worden geconcludeerd dat een grote groep $\mathrm{KMBO}$-schoolverlaters op deze manier werkloosheid heeft weten te vermijden. Opvallend is dat de KMBO'ers desondanks relatief vaak een vaste aanstelling weten te verwerven, ofschoon iets minder vaak dan in 1993. Het aandeel full-time werkenden is daarentegen het afgelopen jaar fors toegenomen. Ook de beloning lijkt redelijk, namelijk ongeveer in het midden van het gemiddelde van VBO'ers en MBO'ers. Gezien de opleidingsduur van het kort MBO lijkt dit logisch.

In figuur 1.5 wordt de kwaliteit van het werk op vergelijkbare wijze samengevat als de kans op het vinden van werk in figuur 1.3. Het patroon in beide figuren is echter geheel verschillend. Naarmate het opleidingsniveau hoger is, wordt gemiddeld genomen tevens een betere kwaliteit van het werk bewerkstelligd. Vooral AVO-schoolverlaters die besluiten direct na het verlaten van de opleiding te gaan werken, moeten vaak de consequentie van een 'slechte' baan aanvaarden. Ook VBO'ers - die vrij snel een baan vinden - komen verhoudingsgewijs vaak in slechtere banen terecht, zoals gezegd vooral tot uitdrukking komend in een lagere beloning.

Voor schoolverlaters van het kort MBO wordt de kwaliteit van het werk ongeveer als gemiddeld getypeerd. Van de hier onderzochte opleidingsniveaus heeft het MBO echter verreweg de beste arbeidsmarktpositie wat betreft de kwaliteit van het werk. Zoals reeds is opgemerkt, bepaalt niet alleen de hogere beloning een aanzienlijk deel van het verschil, maar weten MBO'ers tevens vaker snel een vaste baan te verwerven, die bovendien nauw aansluit bij de opleidingsrichting die zij hebben gevolgd.

6 In hoofdstuk 6 van dit rapport wordt dieper ingegaan op de verschillende vormen van flexibele arbeid 
Figuur 1.5

Kwaliteit van het werk van schoolverlaters per schooltype, 1995

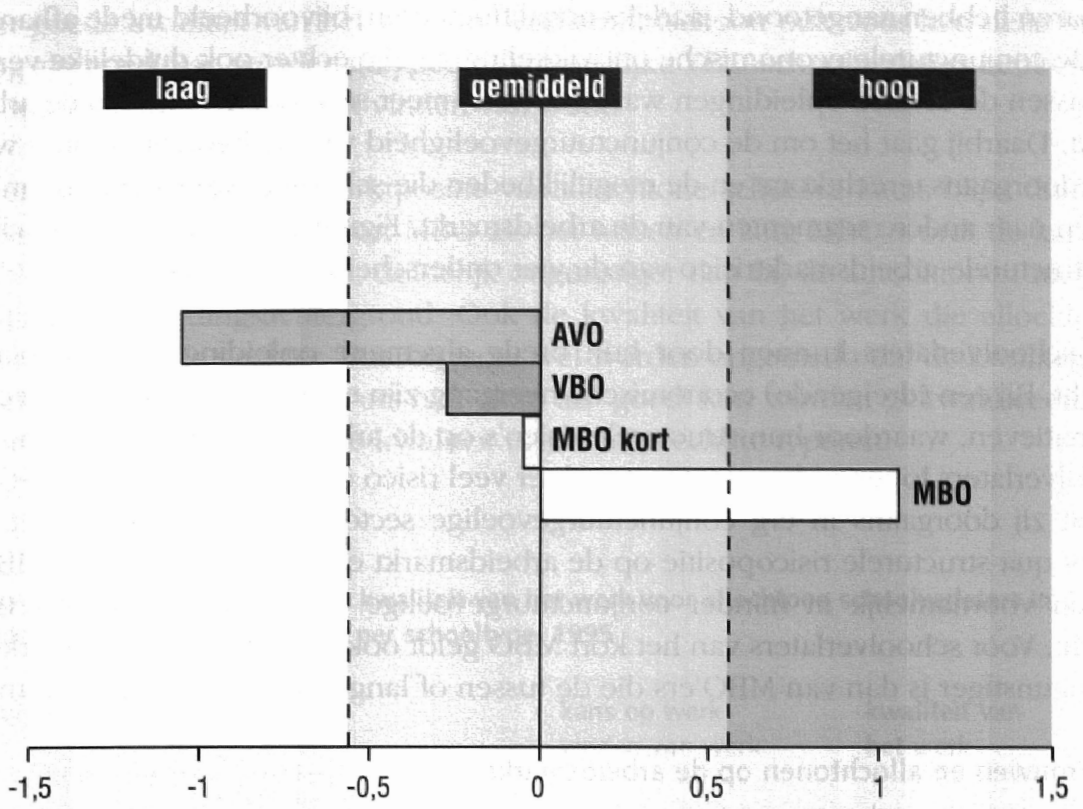

Figuur 1.6

Structureel arbeidsmarktrisico voor schoolverlaters per schooltype, 1995

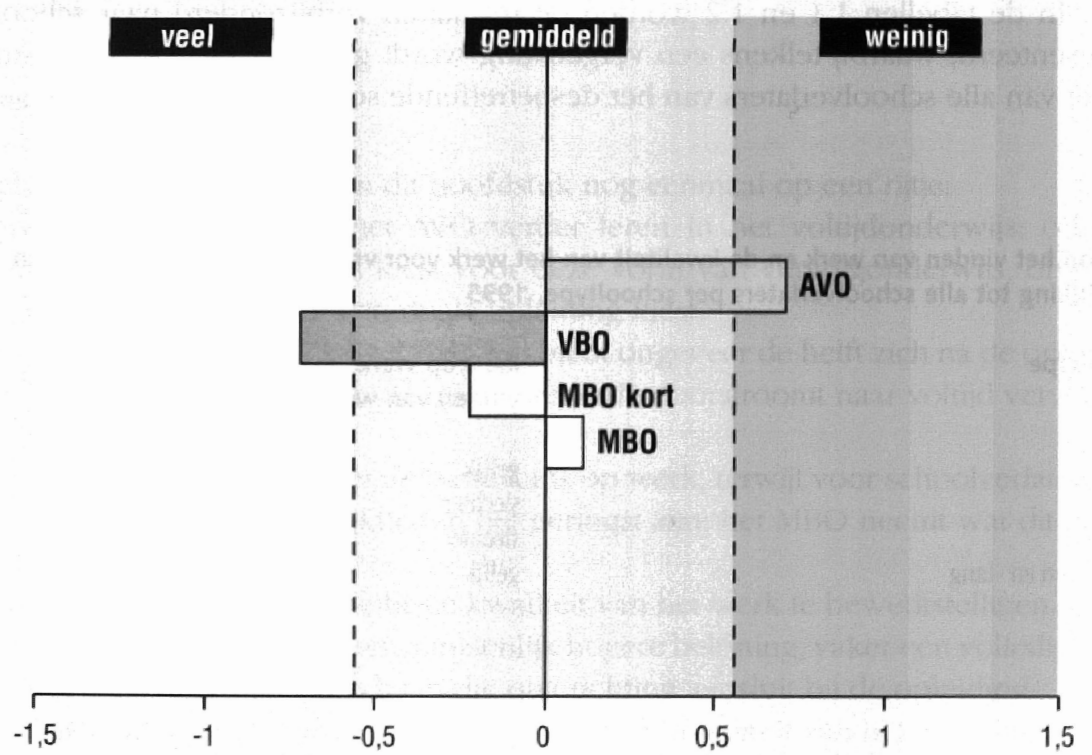




\section{Structurele risicopositie}

De kans op werk en de kwaliteit van het werk kan, zoals de resultaten van de afgelopen jaren hebben aangetoond, jaarlijks nogal fluctueren, bijvoorbeeld mede afhankelijk van de conjuncturele economische ontwikkeling. Er zijn echter ook duidelijke verschillen tussen de diverse opleidingen wat betreft het meer structurele risico op de arbeidsmarkt. Daarbij gaat het om de conjunctuurgevoeligheid van de bedrijfssectoren waarin men doorgaans terechtkomt en de mogelijkheden die schoolverlaters hebben om uit te wijken naar andere segmenten van de arbeidsmarkt. Figuur 1.6 geeft een overzicht van het structurele arbeidsmarktrisico van de vier onderscheiden schooltypen.

AVO-schoolverlaters kunnen door hun brede algemene opleiding op vele plaatsen terecht. Bij een (dreigende) economische neergang zijn er voor hen derhalve meerdere alternatieven, waardoor hun structurele risico's op de arbeidsmarkt beperkt zijn. VBOschoolverlaters lopen in het algemeen echter veel risico op de arbeidsmarkt, met name omdat zij doorgaans in erg conjunctuurgevoelige sectoren terechtkomen. Het MBO neemt qua structurele risicopositie op de arbeidsmarkt een middenpositie in. MBO'ers komen voornamelijk in minder conjunctuurgevoelige bedrijfssectoren dan VBO'ers terecht. Voor schoolverlaters van het kort MBO geldt ook hier dat de arbeidsmarktpositie ongunstiger is dan van MBO'ers die de tussen of lange variant hebben gedaan.

\subsection{Vrouwen en allochtonen op de arbeidsmarkt}

De positie van vrouwen en allochtonen op de arbeidsmarkt is reeds een aantal jaren een belangrijk aandachtspunten bij het te voeren (sociaal en werkgelegenheids-)beleid. In deze paragraaf wordt nagegaan hoe bij respectievelijk vrouwelijke en allochtone schoolverlaters de intrede op de arbeidsmarkt verloopt. Daarbij wordt eveneens een onderscheid gemaakt tussen de kans op het vinden van werk en de kwaliteit van het werk. In de tabellen 1.1 en 1.2 worden de resultaten verbijzonderd naar schooltype gepresenteerd, waarbij telkens een vergelijking wordt gemaakt met de arbeidsmarktpositie van alle schoolverlaters van het desbetreffende schooltype.

Tabel 1.1

Kans op het vinden van werk en de kwaliteit van het werk voor vrouwelijke schoolverlaters in vergelijking tot alle schoolverlaters per schooltype, 1995

\section{Schooltype}

NO

VBO

MBO-kort

MBO-tussen en -lang

\section{kans op werk vinden van werk}

gelijk

slechter

slechter

gelijk

\section{kwaliteit van het werk}

gelijk

gelijk

slechter

slechter

Tabel 1.1 lat zien dat de arbeidsmarktpositie van vrouwelijke schoolverlaters in het algemeen slechter is dan die van hun mannelijke collega's. Bij het kort MBO is niet 
alleen de kans op het vinden van werk lager, maar voor de vrouwelijke schoolverlaters met deze opleidingsachtergrond die wel een baan hebben gevonden betreft dit gemiddeld genomen een kwalitatief slechtere baan. Ook bij het MBO weten vrouwen een iets minder goede kwaliteit van het werk te bereiken, ofschoon ook voor hen deze kwaliteit nog als 'goed' kan worden getypeerd. Vrouwelijke VBO-schoolverlaters hebben met name wat meer moeite met het vinden van werk.

De zeer ongunstige arbeidsmarktpositie van allochtone schoolverlaters blijkt duidelijk uit tabel 1.2. Voor zowel het kort MBO als het tussen en lang MBO wordt de kans op werk als 'erg slecht' getypeerd, duidelijk ongunstiger dan bij de autochtonen met een vergelijkbare opleidingsachtergrond. Ook de kwaliteit van het werk die allochtonen weten te bereiken is slechter. Daarbij moet wel worden opgemerkt dat de kwaliteit van het werk van allochtone MBO'ers nog altijd als 'goed' kan worden gekwalificeerd. Bij het kort $\mathrm{MBO}$ is de gemiddelde kwaliteit echter als slecht te typeren.

Tabel 1.2

Kans op het vinden van werk en de kwaliteit van het werk voor allochtone schoolverlaters in vergelijking tot alle schoolverlaters per schooltype, 1995

\section{Schooltype}

AVO

VBO

MBO-kort

MBO-tussen en -lang

= geen gegevens vanwege kleine aantallen

\section{kans op werk vinden van werk \\ kwaliteit van het werk}

slechter veel slechter slechter slechter

\subsection{Resumé}

De belangrijkste conclusies van dit hoofdstuk nog eenmaal op een rijtje:

- Vrijwel iedereen gaat na het AVO verder leren in het voltijdonderwijs; onk het merendeel van de VBO'ers kiest voor deze vorm van vervolgonderwijs, ofschoon ongeveer een kwart voor een duale opleiding kiest.

- Van zowel de MBO'ers als de KMBO'ers biedt ongeveer de helft zich na de opleiding aan op de arbeidsmarkt, terwijl ruim een derde doorstroomt nat voltijd vervolgonderwijs.

- VBO'ers hebben momenteel de beste kans op werk, terwijl voor schoolverlaters van het kort MBO deze mogelijkheden het geringst zijn; het MBO neemt wat clit betreft een middenpositie in.

- MBO'ers weten verreweg de beste kwaliteit van het werk te bewerkstelligen, vooral tot uitdrukking komend in een aanzienlijk hogere beloning, vaker een volledige aanstelling en tevens vaker een baan die qua richting aansluit bij de opleiding.

- Naarmate het opleidingsniveau lager is, wordt de kwaliteit van het werk lager; AVO. schoolverlaters komen in de 'slechtste' banen terecht.

- Vooral VBO'ers nemen structureel een slechtere positie op de arbeidsmarkt in omdat 
zij sterk zijn gericht op meer conjunctuurgevoelige sectoren.

- Vrouwelijke schoolverlaters vinden in het algemeen moeilijker een baan en komen vaak ook in kwalitatief slechtere banen terecht.

- De arbeidsmarktpositie van allochtone schoolverlaters is duidelijk veel slechter dan die van schoolverlaters met een Nederlandse achtergrond. 


\title{
2 Bestemming van schoolverlaters
}

\begin{abstract}
Algemeen Voortgezet Onderwijs
Meer dan negen van de tien schoolverlaters van het AVO stromen na het behalen van het diploma door naar een voltijd vervolgopleiding. Het AVO fungeert derhalve vrijwel altijd als vooropleiding voor een vervolgstudie en zelden als eindonderwijs. De afgelopen jaren was er sprake van een licht stijgende trend naar een relatief steeds hogere doorstroom naar het voltijd vervolgonderwijs; dit jaar is de participatie blijven steken op het hoge peil van het jaar ervoor. Momenteel kiest 92\% van de MAVO'ers, 91\% van de HAVO'ers en 94\% van de VWO'ers voor een voltijd vervolgopleiding. In figuur 2.1 is de bestemming van schoolverlaters van het AVO in 1994 en 1995 weergegeven.
\end{abstract}

Slechts een kleine minderheid van de gediplomeerde schoolverlaters van het AVO kiest voor een opleiding in het duaal onderwijs, dit wil zeggen een opleiding in het kader van het leerlingwezen (LLW) of een in-service opleiding in de verzorgende sector. Bij het MAVO is dit met een doorstroompercentage van 3\% nog het hoogste. Bovendien is de rechtstreekse doorstroom van AVO'ers naar het leerlingwezen of het in-service onderwijs ten opzichte van vorig jaar nog iets afgenomen. Dit betekent derhalve dat deze zogenaamde nieuwe doelgroepen ${ }^{7}$ nauwelijks doorstromen naar het duaal onderwijs. Zowel voor het MAVO, het HAVO als het VWO geldt dat 4\% van de schoolverlaters een jaar na de afronding van de opleiding als voornaamste bezigheid betaald werk heeft. Andere bestemmingen zoals militaire dienstplicht, werkloosheid of bijvoorbeeld onbetaald werk komen niet of nauwelijks voor.

\section{Voorbereidend Beroeps Onderwijs}

Figuur 2.2 geeft een overzicht van de belangrijkste bestemmingscategorieën van de schoolverlaters van het VBO. Net als in 1994 stroomt een grote meerderheid van de gediplomeerde VBO-schoolverlaters na het verlaten van de initiële opleiding door in een kwalificerend traject: bijna 60\% kiest voor voltijd vervolgonderwijs en ruim een kwart van de VBO'ers gaat een duale opleiding volgen. De doorstroming naar het voltijd vervolgonderwijs is ten opzichte van vorig jaar licht gedaald, terwijl de belangstelling voor vervolgonderwijs in duale vorm juist iets is toegenomen. Hiermee wordt de vorig jaar ingezette daling van de doorstroom van VBO'ers naar het voltijd onderwijs derhalve gecontinueerd. Het gaat echter niet om grote mutaties.

Binnen deze algemene tendens treden tussen de onderscheiden opleidingsclusters overigens beduidende verschillen op. In vergelijking met het vorig jaar is de doorstroom naar het voltijd vervolgonderwijs bij VBO landbouw en VBO dienstverlening/verzorging gestegen en bij VBO techniek juist gedaald. De traditioneel al lage doorstroom van schoolverlaters van VBO techniek naar een voltijd vervolgopleiding wordt hiermee verder geaccentueerd. Momenteel gaat minder dan de helft van de gediplomeerde school-

7 Zie H. Verijd, De instroom van nieuwe doelgroepen in het leerlinguezen. ITS, Nijmegen, 1991 
Bestemming van gediplomeerde schoolverlaters van het AVO, 1994 en 1995

1994
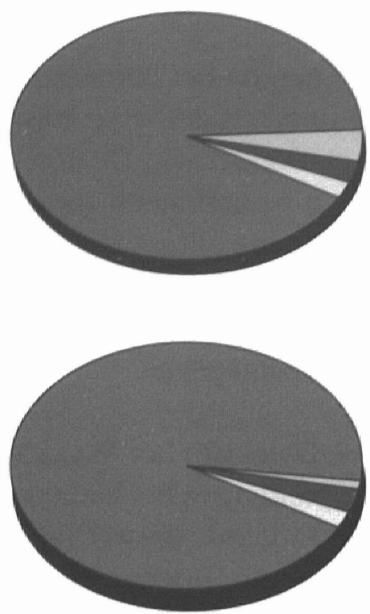

HAVO
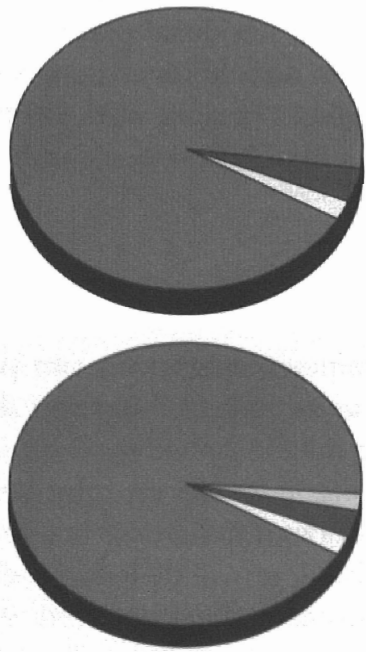

Totaal AVO
1995
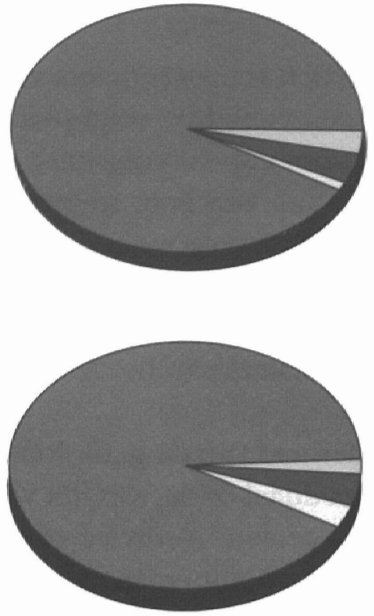

VWO
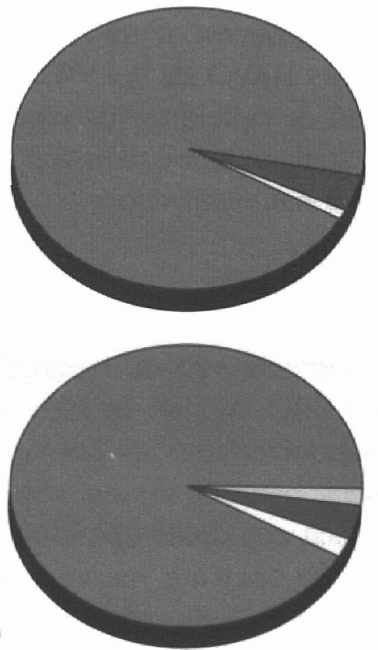

scholier/student $\quad$ betatid werk

I.III/In-servio meris 
Bestemming van gediplomeerde schoolverlaters van het VBO, 1994 en 1995

1994
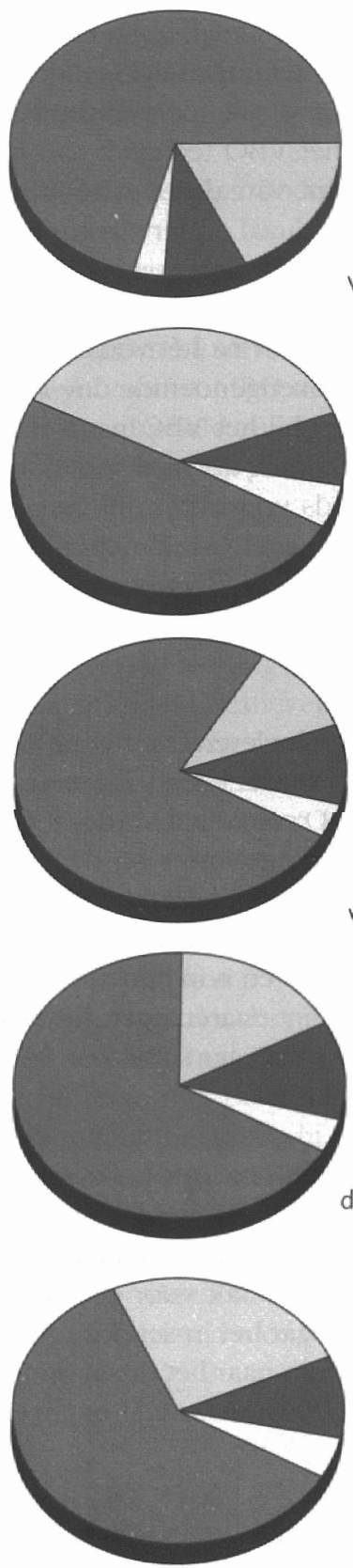

VBO landboum

VBO techniek

VBO economie

VBO dienstverlening/ verzorging

Totaal VBO

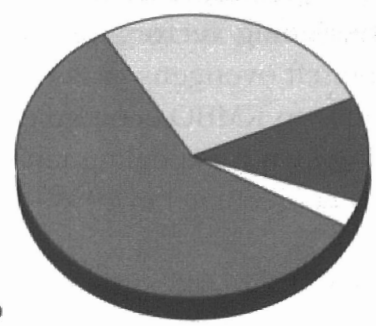

1995
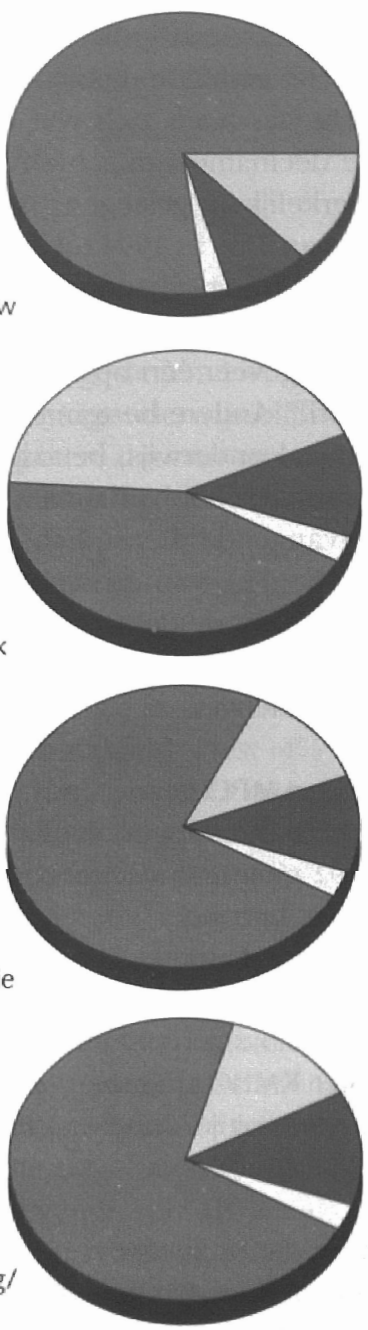

Hetald werh scholier/studern:

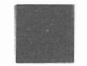

[.LW/in-senict 
verlaters van het VBO techniek voltijd vervolgonderwijs volgen, terwijl dit bij de agrarische, economische en verzorgende sector telkens boven de $70 \%$ ligt.

De geringe doorstroom van schoolverlaters van het VBO techniek naar het voltijd vervolgonderwijs hangt samen met de grotere belangstelling voor het leerlingwezen. Maar liefst $42 \%$ van de gediplomeerde schoolverlaters van het VBO techniek volgt een dergelijke duale opleiding. Het gemiddelde bij de andere VBO-opleidingen ligt veel lager. In vergelijking met vorig jaar heeft zich wat dit betreft een opvallende verschuiving voorgedaan. Terwijl de deelname van schoolverlaters van het VBO techniek aan het duaal onderwijs aanmerkelijk is gestegen, is de doorstroom van de overige VBOschoolverlaters gedaald van $15 \%$ in 1994 tot $13 \%$ in 1995 . Het duaal onderwijs concentreert zich dus nog sterker dan voorheen in de technische sector.

Evenals vorig jaar heeft ongeveer één op de acht VBO'ers een jaar na het verlaten van de opleiding betaald werk ${ }^{8}$. Andere bestemmingen dan de bovengenoemde drie (voltijd vervolgonderwijs, duaal onderwijs, betaald werk) komen bij het VBO nauwelijks voor. Ook het aandeel van de schoolverlaters van het VBO techniek dat na de opleiding eerst de militaire of vervangende dienstplicht vervult, is reeds vrijwel tot nul gereduceerd. In 1992 vervulde nog 3\% van de schoolverlaters van het VBO techniek na het afsluiten van de opleiding eerst de dienstplicht.

\section{Kort Middelbaar Beroeps Onderwijs}

Schoolverlaters van het kort MBO gaan steeds vaker voltijd verder leren (zie figuur 2.3). Tussen 1994 en 1995 is het aandeel schoolverlaters dat is gaan verder leren toegenomen van $28 \%$ tot 36\%. In 1992 ging nog slechts 20\% van de KMBO'ers voltijd verder leren. Deze stijging geldt in het bijzonder voor het grootste opleidingscluster bij de korte MBO-opleidingen, namelijk economie. Hier is sprake van een aanzienlijke toename van $23 \%$ in 1992 tot maar liefst 40\% in 1995. Bij KMBO landbouw en KMBO techniek schommelt de doorstroom naar voltijd vervolgonderwijs van jaar tot jaar en is in het laatste jaar weer iets gedaald. Bij het KMBO dienstverlening/verzorging ligt daarentegen het percentage schoolverlaters dat voltijd door gaat leren de laatste twee jaar stabiel op bijna $30 \%$.

De figuur laat verder zien dat ongeveer een derde van de gediplomeerde schoolverlaters van het KMBO techniek doorstroomt naar een duale opleiding. Dit aandeel ligt veel hoger dan in de overige opleidingsclusters in het kort MBO. Alleen de schoolverlaters van het KMBO dienstverlening/verzorging opteren nog relatief vaak voor een duale vervolgopleiding. Dit betreft overigens vaak een doorstroom naar het in-service onderwijs. Bij KMBO landbouw en KMBO economie is de doorstroom naar het duaal onderwijs onder de 10\%. Dit is een forse daling ten opzichte van 1994, maar wel ongeveer gelijk aan het doorstroompercentage in 1993.

Schoolverlaters van het KMBO landbouw en het KMBO techniek hebben veel vaker betaald werk dan in 1994. In dat jaar bedroeg dit aandeel bij de korte MBO-opleiding

8 Dit betreft dus geen leer-arbeidsplats in het kader van het leerlingwezen of in-service onderwijs. 
landbouw $31 \%$ en dit is nu gestegen tot maar liefst $58 \%$. De stijging bij het KMBO techniek is iets minder pregnant, van ruim een kwart tot bijna $40 \%$. Deze toename heeft wellicht gedeeltelijk te maken met het feit dat zij in minder grote getale de militaire of vervangende dienstplicht zijn gaan vervullen. Van 1994 tot 1995 is het aandeel militaire dienstplichtigen namelijk teruggelopen van $12 \%$ tot $7 \%$. Tot slot is bij het kort MBO 'werkloosheid' geen onaanzienlijke bestemmingscategorie'. Gemiddeld $8 \%$ van de gediplomeerden van het KMBO beschouwt zichzelf als werkloos; bij het KMBO dienstverlening/verzorging is dit zelfs $14 \%$.

\section{Middelbaar Beroeps Onderwijs}

Figuur 2.4 laat zien dat de doorstroom naar het voltijd vervolgonderwijs bij MBO techniek, MBO economie en MBO dienstverlening/verzorging in vergelijking met 1994 licht is gedaald en bij MBO landbouw juist iets is gestegen. Het gemiddelde doorstroompercentage van het MBO naar het voltijd vervolgonderwijs blijft daardoor nagenoeg constant. De algehele trend van een steeds grotere doorstroom van MBO'ers naar een nieuwe voltijd vervolgopleiding lijkt zich derhalve niet door te zetten.

Slechts een kleine minderheid van de schoolverlaters van het MBO gaat aansluitend een duale opleiding volgen. Dit is mede ingegeven door het feit dat de meeste duale opleidingen op een lager of gelijk niveau zijn, het aanbod van tertiare opleidingen in het kader van het leerlingwezen vrij beperkt is en de in-service opleidingen ook niet (in alle gevallen) kwalificatieverhogend zijn. Gemiddeld kiest $4 \%$ van de gediplomeerde MBO'ers voor een duale opleiding; alleen bij het MBO dienstverlening/verzorging ligt dit percentage aanzienlijk hoger. Dit betreft overigens in meer dan 90\% van de gevallen een in-service opleiding in de verpleging of verzorging.

Het gedeelte van de MBO-schoolverlaters dat ongeveer een jaar na het afronden van de opleiding als belangrijkste bestemming betaald werk heeft, is tussen 1994 en 1995 toegenomen tot bijna 50\%. Deze toename doet zich bij vrijwel alle opleidingsclusters voor en hangt vooral samen met de toen al naderende afschaffing van de dienstplicht. In 1994 vervulde nog 7\% van de MBO-schoolverlaters de militaire of vervangende dienstplicht, terwijl dit percentage in 1995 is teruggelopen tot 4\%. Uiteraard speelt bij deze bestemming het geslacht een doorslaggevende rol. Als we alleen de mannelijke gediplomeerde MBO'ers nemen, dan blijkt dat in 1993 nog 22\% van de schoolverlaters de militaire of vervangende dienstplicht vervulde, in 1994 was dit percentage teruggelopen tot $16 \%$ en op basis van de laatste meting in 1995 is dat nog slechts $10 \%$. Door de verkorting van de diensttijd is het overigens ook mogelijk dat (sommige) MBO'ers een jaar na schoolverlaten reeds zijn afgezwaaid.

9 Het gaat hier om het percentage schoolverlaters dar zelf aangeeft dat werkeloosheid de belangrijkste bestemming is en niet om het 'officiëlle' werkeloosheidscijfer. 
1994
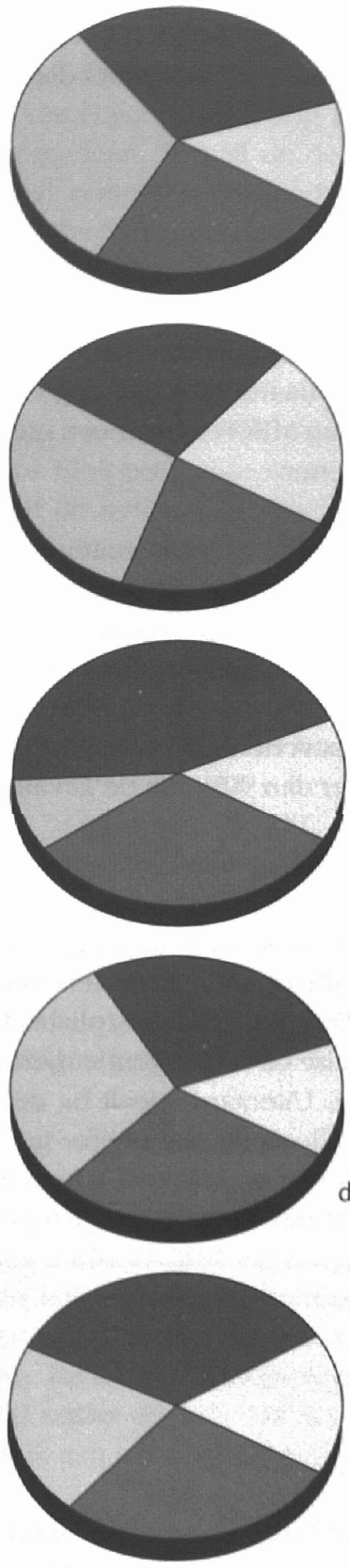

Totaal MBO

MBO-kort

landbouw

MBO-kort techniek

$\mathrm{MBO}$-kort economie

MBO-kort

verzorging
1995
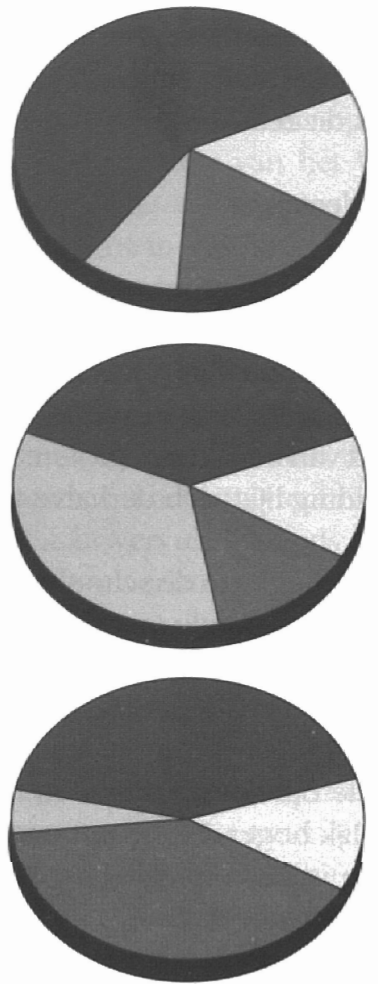
dienstverlening/
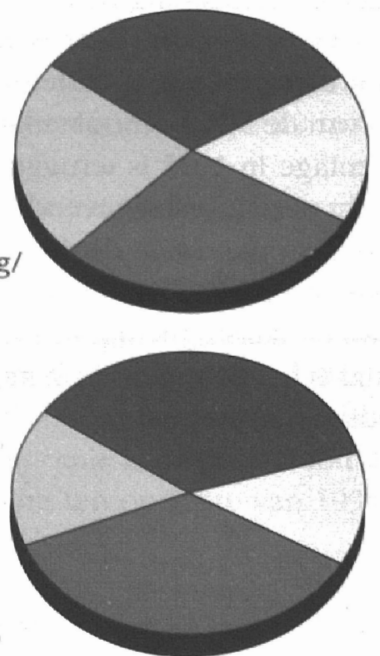

scholiterstudent

betald werk

I.II in serาic 
Figuur 2.t

Bestemming van gediplomeerde schoolverlaters van het MBO, 1994 en 1995
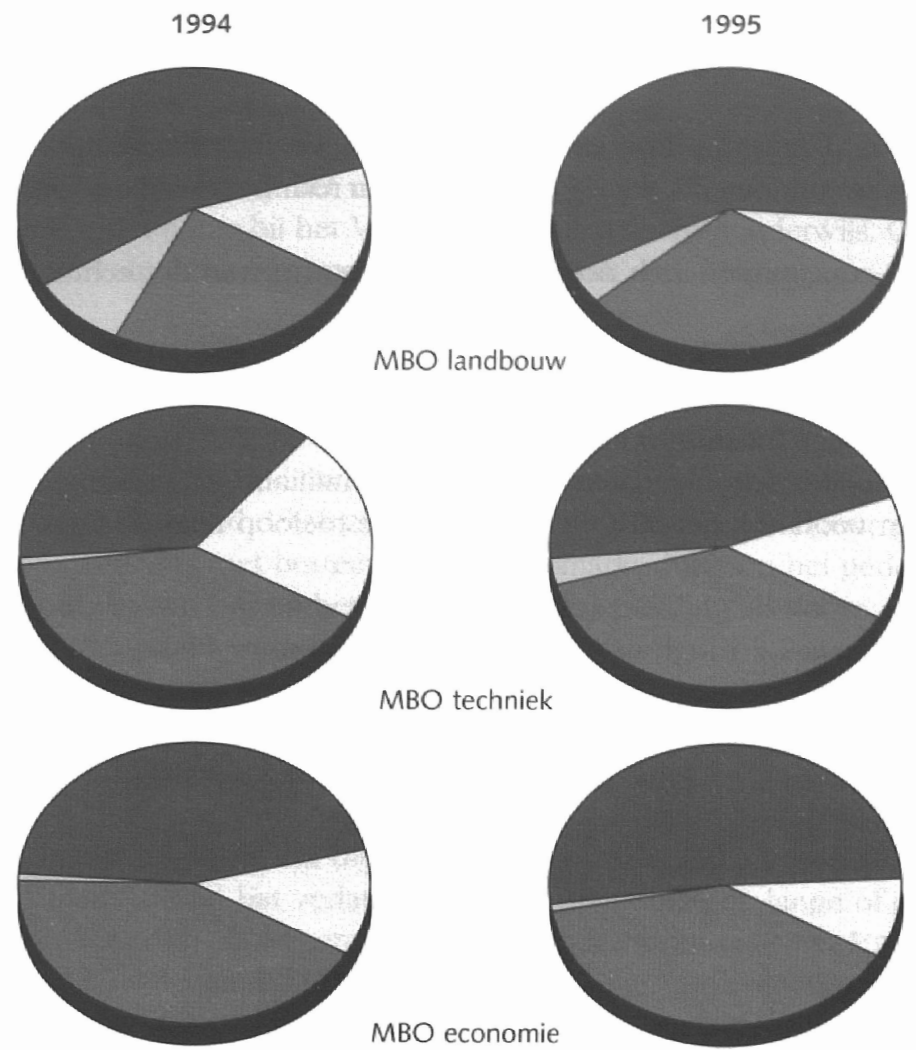

MBO techniek

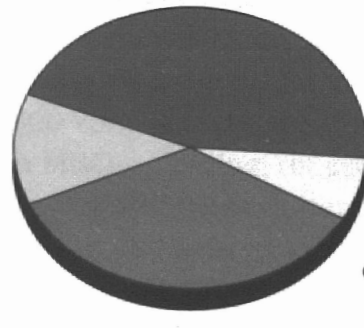

MBO economie
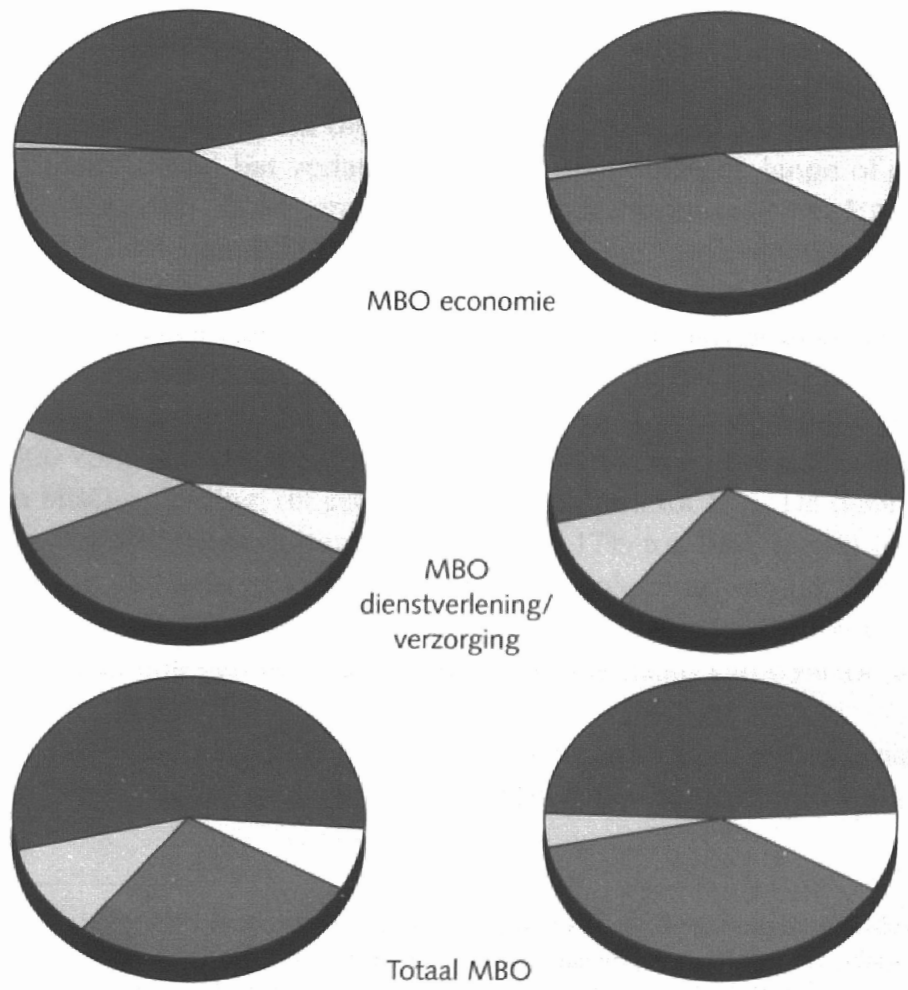

$\mathrm{MBO}$ dienstverlening/

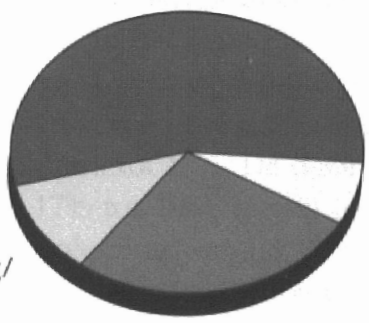

verzorging

Totaal $\mathrm{MBO}$

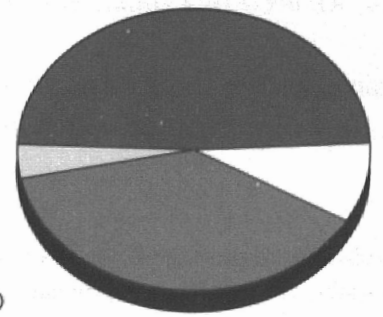




\section{Resumé}

De conclusies uit dit hoofdstuk kunnen als volgt worden samengevat:

- Meer dan negen van de tien schoolverlaters van het AVO gaan full-time verder leren; de doorstroom naar het duaal onderwijs is het afgelopen jaar nog verder afgenomen tot nauwelijks 3\%.

- De vorig jaar ingezette daling van de doorstroom van VBO'ers naar het voltijd vervolgonderwijs wordt gecontinueerd, terwijl de doorstroom naar het duaal onderwijs licht toeneemt.

- Het duaal onderwijs concentreert zich nog sterker dan voorheen in de technische sector.

- De doorstroom van het kort MBO naar het voltijd vervolgonderwijs blijft stijgen; bij de tussen en lange opleidingen van het MBO is de doorstroming naar het voltijd vervolgonderwijs daarentegen tot stilstand gekomen.

- Steeds minder mannelijke schoolverlaters vervullen de militaire of vervangende dienstplicht, hetgeen vooral bij het MBO leidt tot grotere toeloop naar de arbeidsmarkt. 


\section{Doorstroom naar vervolgonderwijs}

\subsection{Stromen in het onderwijs}

In het vorige hoofdstuk is geconstateerd dat een groot gedeelte van de schoolverlaters verder gaat leren. In het merendeel van de gevallen is dit voltijd vervolgonderwijs en soms - met name bij het VBO - is dit duaal vervolgonderwijs. Op deze beide vormen van vervolgonderwijs wordt in dit hoofdstuk nader ingegaan.

Evenals in de rapportage van afgelopen jaar wordt in een samenvattend schema de bestemming van schoolverlaters verbijzonderd naar schooltype afgebeeld (zie figuur 3.1 op pag 22$)^{10}$. Voor de uitstroomgegevens van het $\mathrm{HBO}$ is gebruik gemaakt van de HBO-monitor 1994, dit wil zeggen de uitstroom van gediplomeerden van het schooljaar 1992/'93 die eind 1994 zijn genquêteerd" ${ }^{1}$. Het in de figuur genoemde percentage schoolverlaters met bestemming arbeidsmarkt duidt op het gedeelte van de totale uitstroom dat een jaar na het verlaten van de opleiding als voornaamste bezigheid 'werkloos' of 'betaald werk' heeft. Verder zijn er in figuur 3.1 absolute aantallen gepresenteerd. Deze aantallen zijn gebaseerd op de Referentieraming 1994 van het Ministerie van Onderwijs, Cultuur en Wetenschappen en hebben betrekking op het totaal aantal gediplomeerden van het schooljaar 1993/'94.

Uit figuur 3.1 blijkt dat bijna driekwart van de gediplomeerde MAVO-schoolverlaters een klein jaar na het verlaten van deze opleiding een lange of tussen MBO-opleiding volgt. Daarnaast is er een aanzienlijke doorstroom naar het HAVO, terwijl slechts een beperkt deel een korte MBO-opleiding volgt. Ook de directe doorstroom naar de arbeidsmarkt is gering. De verschuivingen ten opzichte van 1994 zijn daarbij minimaal. Bij de uitstroom van HAVO'ers is echter wel een aanzienlijke verschuiving vast te stellen. Er is namelijk een geringere doorstroom van het HAVO naar het MBO en VWO, terwijl een groter gedeelte van de HAVO'ers kiest voor de 'koninklijke leerroute' naar het HBO. Vorig jaar volgde $26 \%$ van de gediplomeerde havisten in het daaropvolgende jaar een MBO-opleiding; dit jaar is dit teruggelopen tot 19\%. De doorstroom naar het VWO is in dezelfde periode teruggelopen van $17 \%$ tot $10 \%$, terwijl inmiddels meer dan de helft van de havisten kiest voor een HBO-opleiding. Van de VWO-schoolverlaters kiest eveneens een groter gedeelte voor het HBO. De doorstroming van VWO'ers naar het WO is daarentegen het afgelopen jaar fors gedaald van $65 \%$ tot $56 \%$.

Vier van de tien VBO'ers gaan na het behalen van het diploma naar het MBO en ongeveer één op de zes gaat naar het kort MBO. Ten opzichte van 1994 is de doorstroom van

10 In de figuur wordt geen onderscheid gemaakt naar de gevolgde opleidingsector of de vooroplei ding. Zie LDC, Loophanen in bet beroepsonderwijs: trajecten en schema's in 13 schema's, LDC. Leeuwarden, 1995, waarin op basis van de RUBS-enquête 1994 door middel van 13 schema's cen beeld wordt gegeven van de schoolloopbanen van (K)MBO'ers.

11 P.J.E. van de Loo, J. Hoevenberg, R.K.W. van der Velden, De arbeidsmarkipositie van afgestudeerden van bet hoger beroepsonderwijs: HBO-Monitor 1994, Voorlichtingsdienst HBO-Raad, Den Haag, 1995. 
VBO'ers naar het MBO enigszins gedaald en de doorstroming naar het KMBO licht gestegen. De uitstroom naar het primair leerlingwezen en naar de arbeidsmarkt is nagenoeg gelijk gebleven.

Zoals reeds in het vorige hoofstuk is gebleken, is de doorstroom van schoolverlaters van het kort MBO naar het duaal onderwijs ten opzichte van het jaar ervoor gedaald. De figuur laat zien dat in het voorjaar van 1995 6\% van de KMBO-schoolverlaters een primaire opleiding in het kader van het leerlingwezen volgt, $9 \%$ een voortgezette leerlingwezenopleiding en slechts $1 \%$ een in-service opleiding. In vergelijking met vorig jaar zijn meer KMBO'ers zijn een tussen of lange MBO-opleiding gaan volgen, terwijl tevens iets meer KMBO'ers de arbeidsmarkt zijn opgegaan.

Voor meer dan de helft van de schoolverlaters van het $\mathrm{MBO}$ is deze opleiding het eindonderwijs: $52 \%$ biedt zich aan op de arbeidsmarkt. Het merendeel heeft inderdaad een baan gevonden en een kleine minderheid beschouwt zichzelf als werkloos. Vorig was het gedeelte van de MBO'ers dat naar de arbeidsmarkt ging net iets minder dan de helft, zodat er van een lichte stijging kan worden gesproken. Het aandeel MBO'ers dat de schoolloopbaan vervolgt met een $\mathrm{HBO}-$ opleiding is eveneens enigszins gestegen.

HBO'ers bieden zich na het afsluiten van de opleiding meestal aan op de arbeidsmarkt. Ook hier is een lichte toename ten opzichte van vorig jaar waar te nemen. Het aandeel HBO-afgestudeerden dat daarna een universitaire opleiding gaat volgen is - in vergelijking met het jaar ervoor - licht gedaald. Waarschijnlijk vindt deze recente daling enerzijds zijn oorsprong in het feit dat het Ministerie van Onderwijs, Cultuur en Wetenschappen het 'stapelen' van het opleidingen in het hoger onderwijs heeft bemoeilijkt en anderzijds heeft mogelijk de verbeterde arbeidsmarktsituatie voor HBO'ers de belangstelling voor het universitair onderwijs vermindert ${ }^{12}$.

\subsection{De keuze voor vervolgonderwijs}

In deze paragraaf zal worden nagegaan welke factoren de keuze voor vervolgonderwijs beïnvloeden. Enigszins afhankelijk van het schooltype zullen de verschillen in doorstroomgedrag tussen onder meer mannen en vrouwen en allochtonen en autochtonen aan de orde komen. Tevens wordt nagegaan in hoeverre de keuze voor een bepaald vervolgtraject samenhangt met bijvoorbeeld het niveau van het vakkenpakket of de gevolgde vooropleiding ${ }^{13}$.

\section{Algemeen Voortgezet Onderwijs}

In het AVO is er niet of nauwelijks sprake van een verschil in doorstroom naar een voltijd vervolgopleiding tussen mannen en vrouwen of tussen allochtonen en autochtonen. verder is nagegaan of er verschillen bestaan wat betreft het type vervolgonderwijs.

12 Zie ook P.I.E. van de Loo. J. Hoevenberg. R.K.W. van der Velden, 1995, op cit.

13 Voor deze analyses zijn verschillende modellen gespecificeerd, waarvan de schattingsresultaten zijn opgenomen in M. van smoorenburg en E. Willems, 1996, op cit. (zie ook het geelgekleurde kader op bladzijde 21 ). 
Daarbij is gekeken naar de directe doorstroom van het MAVO naar het MBO, van het HAVO naar het HBO en van het VWO naar het WO. Ten aanzien van deze min of meer normale doorstroompatronen blijken er wel enige verschillen te bestaan. Allochtone MAVO'ers gaan minder vaak naar het MBO dan autochtone MAVO'ers. Daarnaast blijkt dat vrouwelijke VWO-schoolverlaters veel minder vaak voor het wetenschappelijk onderwijs kiezen dan mannelijke schoolverlaters van deze opleiding. Van de vrouwelijke VWO'ers gaat iets minder dan de helft naar de universiteit, terwijl van de mannelijke VWO'ers bijna twee derde een universitaire studie gaat volgen. Voorts geldt dat vrouwelijke schoolverlaters minder vaak doorstromen naar het duaal onderwijs. Wat dit betreft zijn de verschillen tussen allochtonen en autochtonen niet bijzonder groot.

\section{Voorbereidend Beroeps Onderwijs}

De keuze van VBO-schoolverlaters voor het aansluitend volgen van een voltijd vervolgopleiding hangt vooral samen met het niveau van het vakkenpakket en het opleidingscluster dat men heeft gevolgd. Het geslacht, de etniciteit of de regio waar de VBO'er woont speelt hierbij niet of nauwelijks een rol. Om een zuiver beeld te geven van het verschil in keuze van VBO'ers voor verschillende vormen van vervolgonderwijs, is in tabel 3.1 aangegeven wat het netto verschil in doorstroompercentage naar vervolgonderwijs ten opzichte van een bepaalde referentiecategorie is (zie ook de toelichting in het geelgekleurde kader op pagina 24) ${ }^{14}$. Voorbeeld: Van de VBO-schoolver-

Tabel 3.1

Netto effect van enkele factoren op de keuze van vervolgonderwijs door schoolverlaters van het VBO (in procentpunten ten opzichte van het gemiddelde van de referentiegroep)

\section{Verklarende \\ factoren}

Opleidingscluster

VBO landbouw

VBO techniek (referentiegroep)

VBO economie

VBO dienstverlening/verzorging

\section{Examenprofiel}

A/B-profiel (referentiegroep)

C/D-profiel

Geslacht

Mannen (referentiegroep)

Vrouwen

\section{Etniciteit}

Autochtonen (referentiegroep)

Allochtonen

$\begin{array}{cc}\text { voltijd } & \text { MBO- } \\ \text { onderwijs } & \text { kort }\end{array}$

MBO

$\begin{array}{cc}+28^{*} & -8^{*} \\ (43 \%) & (13 \%) \\ +19^{*} & +10^{*} \\ +16^{*} & -2+\end{array}$

$(20 \%)$

$-11 *$

$(50 \%)$

$+3$

$(13 \%)$

$+6$

$(58 \%)$

$+10$ duaal
onderwijs

kwalificerend traject

* = significant op $5 \%$-niveau

14 Vanwege de overzichtelijkheid zijn alleen de belangrijkste in de analyse opgenomen factoren in de. tabel opgenomen. 


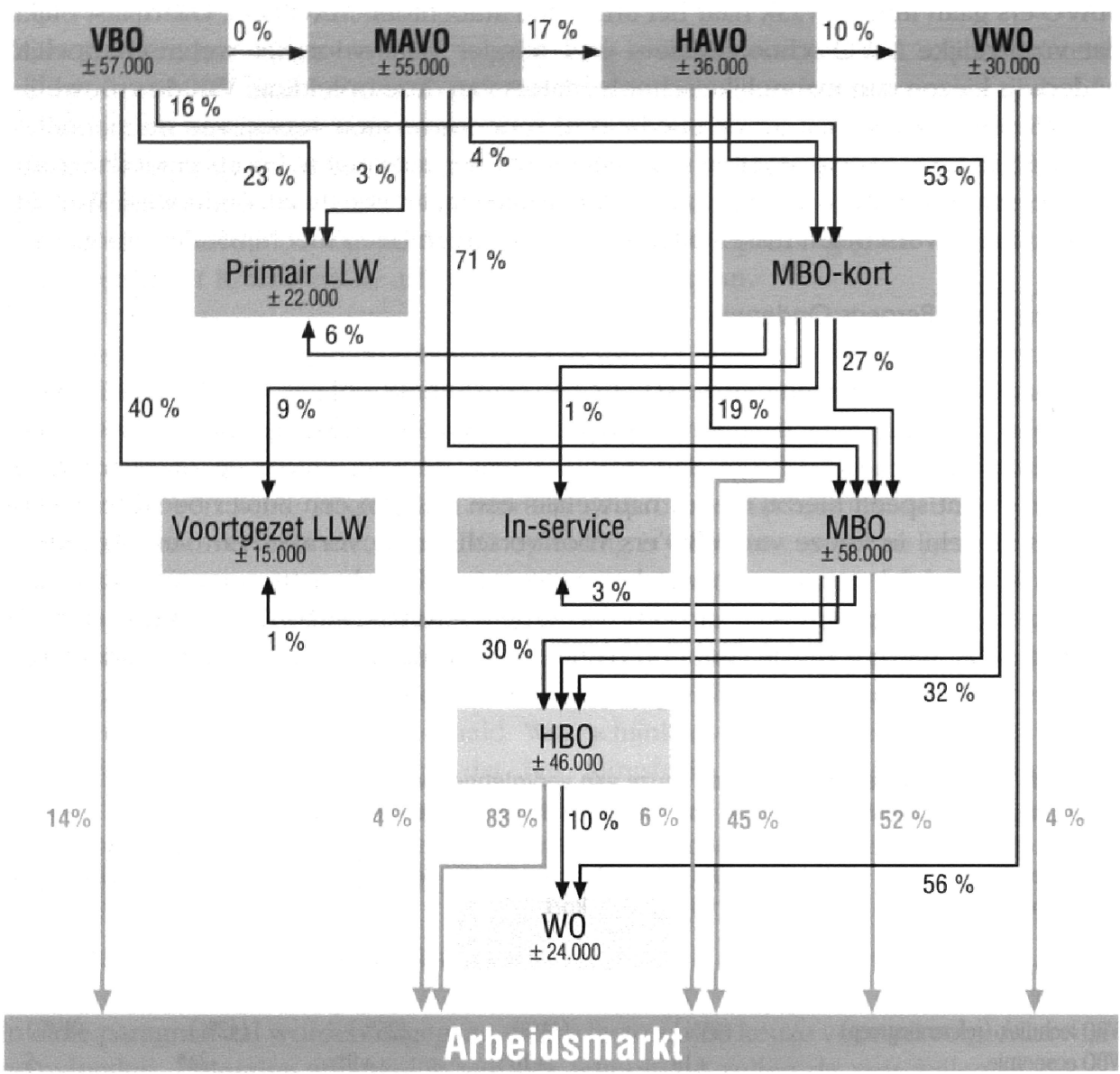

laters die examen hebben gedaan op A/B-niveau stroomt 38\% door naar het voltijd vervolgonderwijs. Van een verder vergelijkbare groep VBO-schoolverlaters met een examenpakket op C/D-niveau gaat echter maar liefst $66 \%$ voltijd verder leren. We spreken in dit geval van een netto verschil van +28 procentpunten. Dit verschil geldt overigens uitsluitend voor de doorstroom naar het MBO-tussen en -lang; de beter geprofileerde VBO'ers gaan juist minder vaak naar het MBO-kort. Zoals reeds eerder is opgemerkt, is ook het opleidingscluster zeer bepalend voor de keuze om een voltijdse vervolgopleiding te gaan volgen. Schoolverlaters van VBO landbouw en VBO dienstverlening/verzorging gaan vaak na afloop van hun opleiding naar het $\mathrm{MBO}$. Daarentegen gaan schoolverlaters van het VBO techniek minder vaak full-time doorleren.

Bij de doorstroom van VBO'ers naar het duaal onderwijs speelt het niveau van het vakkenpakket dat een schoolverlater heeft gevolgd en het opleidingscluster eveneens een belangrijke rol. De effecten zijn in dit geval echter precies omgekeerd. De qua niveau van het vakkenpakket beter geprofileerde VBO'ers gaan minder vaak naar het duaal 
onderwijs. Van de opleidingsclusters binnen het VBO is de doorstroom naar een duale opleiding duidelijk het hoogst bij het VBO techniek. Opmerkelijk is verder dat - anders dan bij de doorstroom naar het voltijd vervolgonderwijs - de etnische afkomst van schoolverlaters wel van invloed is op de keuze voor het gaan volgen van een duale vervolgopleiding. Het blijkt dat allochtone VBO'ers opvallend minder vaak doorstromen naar een duale opleiding.

De doorstroompatronen naar beide soorten vervolgonderwijs (voltijd en duaal) zijn bovendien samen geanalyseerd. Dit kan worden gezien als de mate waarin VBO'ers na het verlaten van hun opleiding doorstromen naar een kwalificerend traject (zie de laatste kolom van tabel 3.1). Weliswaar gaan er relatief weinig schoolverlaters van het VBO techniek naar het voltijd vervolgonderwijs, maar omdat er relatief veel schoolverlaters van het VBO techniek naar het duaal onderwijs gaan, is het effect per saldo ongeveer nul. Wat betreft het niveau van het vakkenpakket is reeds vastgesteld dat schoolverlaters met minimaal drie vakken op C-niveau vaker een voltijd vervolgopleiding en minder vaak een duale opleiding gaan volgen. Bij dit aspect is het saldo van beide effecten echter opvallend genoeg niet nul. De beter geprofileerde VBO'ers volgen namelijk vaker een kwalificerend traject. Of anders gesteld, de VBO'ers met een A/B-profiel willen vaker direct na het afsluiten van de opleiding gaan werken.

\section{Kort Middelbaar Beroeps Onderwijs}

Het al dan niet gaan volgen van een voltijd vervolgopleiding na afloop van een korte MBO-opleiding hangt met name samen met het soort opleidingscluster dat deze schoolverlaters hebben afgerond. Tabel 3.2 laat zien dat gediplomeerde KMBO'ers die een economische of dienstverlenend/verzorgende opleiding hebben gevolgd vaker voor

Tabel 3.2

Netto effect van enkele factoren op de keuze van vervolgonderwijs door schoolverlaters van het kort $\mathrm{MBO}$ (in procentpunten ten opzichte van het gemiddelde van de referentiegroep)

\section{Verklarende \\ factoren}

Opleidingscluster

MBO-kort landbouw

MBO-kort techniek (referentiegroep)

MBO-kort economie

MBO-kort dienstverlening/verzorging

\section{Geslacht}

Mannen (referentiegroep)

Vrouwen

Etniciteit

Autochtonen (referentiegroep)

Allochtonen

$\begin{array}{ccc}\text { voltijd } & \begin{array}{c}M B O- \\ \text { kort }\end{array} & \text { MBO } \\ \text { onderwijs } & \text { r }\end{array}$

\section{duaal}

onderwijs

$\begin{array}{cccc}+3 & -0 & +3 & -21^{*} \\ (14 \%) & (2 \%) & (7 \%) & (34 \%) \\ +24^{*} & -2^{*} & +26^{*} & -27^{*} \\ +16^{*} & -1 & +21^{*} & +0 \\ & & & \\ (30 \%) & (2 \%) & (24 \%) & (23 \%) \\ -0 & +2 & -6 & -9^{*} \\ & & & \\ (33 \%) & (4 \%) & (26 \%) & (18 \%) \\ +13^{*} & +9^{*} & +1 & -9^{*}\end{array}$

* = significant op 5\%-niveau 


\section{Het bepalen van netto effecten van de doorstroom naar vervolgonderwijs}

Voor bet bepalen van het zogenaamde gecorrigeerde of netto effect van de verschillende factoren, wordt eerst een model geschat dat de doorstroom van scboolverlaters naar de verscbillende vormen van vervolgonderwijs aan de band van deze factoren tracht te verklaren. Vervolgens wordt uitgegaan van het gemiddeld doorstroompercentage voor een specifieke referentiegroep, bijvoorbeeld de mannen. Het netto verschil in doorstroom naar vervolgonderwijs tussen mannen en vrouwen wordt dan verkregen door de vergelijking met bet berekende doorstroompercentage voor vrouwen met verder exact dezelfde acbtergrondkenmerken, dat wil zeggen zelfde opleiding, zelfde etnische achtergrond enz., voorzover deze in bet model zijn opgenomen.

Voorbeeld: Van de schoolverlaters van het VBO techniek (de referentiegroep) gaat gemiddeld $43 \%$ aansluitend een voltijd vervolgonderwijs volgen. Van een vergelijkbare groep schoolverlaters, dat wil zeggen dezelfde man/vrouw verbouding als bij $V B O$ techniek, dezelfde verbouding allochtoon/autochtoon enz., van bet VBO dienstverlening/verzorging zou volgens bet gehanteerde model 59\% doorstromen naar een andere voltijd opleiding: het verschil bedraagt derbalve 16 procentpunten. Deze netlo effecten geven een zuiverder beeld, aangezien de resultaten niet worden 'vertekend' door de andere beinvloedende factoren, bijvoorbeeld in bet VBO techniek zitten minder vrouwen, betgeen ook zijn neerslag heeft op de doorstroom naar vervolgonderwijs. Op deze manier kan derhalve bet effect van de gevolgde opleiding en van bijvoorbeeld geslacht of etniciteit van elkaar worden gescheiden.

een voltijd (MBO-)vervolgopleiding kiezen dan de technisch opgeleide KMBO'ers ${ }^{15}$. Verder blijkt dat allochtone KMBO'ers, die overigens sterk binnen dit schooltype zijn vertegenwoordigd", vaker een full-time vervolgopleiding gaan volgen. Dit is in vele gevallen opvallend genoeg een nieuwe korte MBO-opleiding.

Schoolverlaters van de korte MBO-opleidingen economie en landbouw stromen relatief minder valak door natr het duatal onderwijs, terwijl schoolverlaters van KMBO techniek en $\mathrm{KMBO}$ dienstverlening/verzorging juist valak voor de combinatie van werken en leren opteren. Verder kiezen mannen na hun korte MBO-opleiding vaker voor het duaal onderwijs dan vrouwen. Ook autochtonen stromen vaker door naar deze vorm van onderwijs. In beicle gevallen bedratagt het verschil 9 procentpunten.

Middelbaar Beroeps Onderwijs

Tabel 3.3 geeft cen overzicht van de netto effecten van de gevolgde en de vooropleiding, het gestacht en de etniciteit van MBO-schoolverlaters op hun keuze voor vervolgonderwijs. De tabel latat zien dat vrouwen na afloop van de MBO-opleiding veel

15 Daarnatst stromen degenen die een schakelopleiding in het kort MBO hebben afgerond relatief vali deor naar hee tussen of ling MBO.

16 Zic Kermegerems tabel 2. 
Tabel 3.3

Netto effect van enkele factoren op de keuze van vervolgonderwijs door schoolverlaters van het $\mathrm{MBO}$ (in procentpunten ten opzichte van het gemiddelde van de referentiegroep)

\section{Verklarende}

factoren

Opleidingscluster

MBO landbouw

MBO techniek (referentiegroep)

MBO economie

$\mathrm{MBO}$ dienstverlenend/verzorging

Vooropleiding

MAVO (referentiegroep)

HAVO/NWO

VBO

MBO-kort

Geslacht

Mannen (referentiegroep)

Vrouwen

Etniciteit

Autochtonen (referentiegroep)

Allochtonen

* = significant op $5 \%$-niveau

\section{$\mathrm{HBO}$}

$\begin{array}{cc}\text { HBO } & \begin{array}{c}\text { duaal } \\ \text { onderwijs }\end{array}\end{array}$

$(30 \%)$

$+2$

$+10^{\text {* }}$

$(3 \%)$

$-2^{*}$

$+6$

$(32 \%)$

$+8^{*}$

$-15^{*}$

$-23^{*}$

(4\%)

$2^{*}$

$+2^{\text {* }}$

2

(35\%)

$-16^{*}$

(4\%)

$+0$

$(30 \%)$

$(4 \%)$

$+8=$

minder vaak naar het HBO gaan dan mannen. Het valt verder op dat allochtonen - ten opzichte van autochtonen - juist vaker doorstromen naar het voltijd vervolgonderwijs, in casu het HBO. Er zijn wat betreft de doorstroom naar het $\mathrm{HBO}$ in het algemeen weinig verschillen tussen de onderscheiden opleidingsclusters. Wel kiezen de MBO-schoolverlaters met een dienstverlenende of verzorgende opleiding iets vaker om in het HBO door te leren.

De opleiding die schoolverlaters voorafgaand aan het $\mathrm{MBO}$ hebben gevolgd ${ }^{17}$ blijkt veel meer een bepalende factor te zijn bij de keuze om al dan niet in het HBO verder te studeren. MBO'ers met een HAVO/VWO-vooropleiding gaan vaker naar het HBO dan MBO'ers die eerst MAVO hebben gedaan. Dit wijst derhalve op een zeer inefficiënte leerroute. MAVO-instromers gaan op hun beurt weer vaker verder leren in het HBO dan respectievelijk MBO'ers met een VBO- of KMBO-vooropleiding.

Zoals reeds in aangegeven in hoofdstuk 2, gaat een klein deel van de MBO-schoolverlaters aansluitend een duale opleiding volgen, met name een in-service opleiding in de verpleging of verzorging. Het wekt dan ook weinig verbazing dat de schoolverlaters van $\mathrm{MBO}$ dienstverlening/verzorging relatief vaak naar het duaal onderwijs doorstromen. Voorts blijkt dat MBO'ers die zijn ingestroomd vanuit het VBO vaker voor een dergelijke vervolgopleiding kiezen en HAVO/VWO-instromers juist minder vaak.

17 Een overzicht van de vooropleiding van schoolverlaters van MBO en kort MBO is weergegeven in de Kerngegevens, tabel 4 . 
Vrouwen zijn veel minder trouw aan een eenmaal gekozen opleidingssector dan mannen. Dit blijkt uit een analyse van het doorstroomgedrag van gediplomeerde schoolverlaters van het VBO en het (kort) MBO, waarvan de resultaten zijn gepresenteerd in tabel 3.4. Van de verder lerende mannen van het beroepsonderwijs zet $79 \%$ zijn opleiding in dezelfde sector zijn opleiding voort. Bij een vergelijkbare groep vrouwen is dit slechts 58\%: een verschil van maar liefst 21 procentpunten. Tussen allochtonen en autochtonen bestaan er wat dit betreft daarentegen geen verschillen.

Verder is gekeken naar het netto effect van het gevolgde opleidingscluster op de doorstroom van schoolverlaters binnen dezelfde onderwijssector. Het blijkt dat schoolverlaters van een dienstverlenende of verzorgende opleiding er relatief vaak voor kiezen aansluitend een tweede of derde opleiding in deze richting te gaan volgen. Een dergelijk patroon is op alle onderscheiden opleidingsniveaus zichtbaar. Dit geldt overigens uitsluitend voor de vrouwelijke schoolverlaters van een verzorgende/dienstverlenende opleiding. Een vergelijkbare analyse, verbijzonderd naar geslacht laat zien dat de mannelijke schoolverlaters van een verzorgende of dienstverlenende opleiding kennelijk vaak spijt hebben; zij wisselen vrij vaak van opleidingssector. Erg opvallend is verder dat schoolverlaters van een korte $\mathrm{MBO}$-opleiding in de technische richting hun oplei-

Tabel 3.4

Netto effect van enkele factoren op de doorstroom van schoolverlaters van het VBO en (kort) MBO naar een vervolgopleiding in dezelfde opleidingssector (in procentpunten ten opzichte van het gemiddelde van de referentiegroep)

\title{
Verklarende \\ factoren
}

\author{
aansluitend \\ vervolgonderwijs
}

Opleidingscluster

VBO landbouw

$-4$

VBO techniek

$+0$

VBO economie

VBO dienstverlening/verzorging

MBO-kort landbouw

MBO-kort techniek

MBO-kort economie

MBO-kort dienstverlening/verzorging

MBO landbouw

MBO techniek (referentiegroep)

MBO economie

MBO dienstverlening/verzorging

Geslacht

Mannen (referentiegroep)

Vrouwen

Etniciteit

Autochtonen (referentiegroep)

Allochtonen

* = significant op $5 \%$-niveau 
ding nogal eens voortzetten in een andere richting. In vergelijking met het MBO techniek bedraagt het verschil maar liefst bijna 20\%punten.

\subsection{Resumé}

Puntsgewijs worden hieronder de voornaamste conclusies uit dit hoofdstuk samengevat:

- Zowel HAVO-, VWO- als MBO-schoolverlaters gaan vaker dan in 1994 naar het $\mathrm{HBO}$.

- Schoolverlaters van het MBO-kort gaan in vergelijking met vorig jaar iets minder vaak naar het duaal onderwijs en iets vaker naar het MBO-tussen en -lang.

- Vrouwelijke VWO'ers gaan minder vaak dan in 1994 een universitaire opleiding volgen dan mannelijke VWO'ers.

- Gediplomeerde VBO'ers met minimaal drie vakken op C-niveau gaan veel vaker naar het $\mathrm{MBO}$, minder vaak naar het kort $\mathrm{MBO}$ en eveneens minder vaak naar het duaal onderwijs; gediplomeerde VBO'ers met een A/B-profiel volgen minder vaak een kwalificerend traject.

- Allochtone VBO'ers en vooral allochtone KMBO'ers gaan minder vaak naar het duaal vervolgonderwijs; daarentegen gaan zij wel iets vaker naar het voltijd vervolgonderwijs.

- Vrouwelijke MBO-schoolverlaters gaan minder vaak naar het HBO dan mannelijke MBO-schoolverlaters.

- MBO'ers met reeds een voltooide VBO- of korte MBO-opleiding gaan minder vaak naar het HBO dan MBO'ers die hun schoolloopbaan in het AVO, met name het HAVO, zijn begonnen.

- Vrouwen houden minder sterk vast aan een eenmaal gekozen opleidingsector dan mannen. 


\section{Intrede op de arbeidsmarkt}

\subsection{Het aanbieden op de arbeidsmarkt}

Scholieren maken aan het eind van hun opleiding een keuze om zich al dan niet aan te bieden op de arbeidsmarkt. Deze keuze zal onder meer beünvloed worden door enerzijds de motivatie en capaciteiten en anderzijds de ingeschatte netto opbrengst van enkele jaren verder leren. Daarbij zal onder meer een afweging worden gemaakt tussen de verwachte hogere beloning na een hogere opleiding en de te maken directe en indirecte kosten van deze opleiding. In dit verband speelt bijvoorbeeld ook de verwachte verblijfsduur op de arbeidsmarkt een rol. Als een schoolverlater slechts kortstondig op de arbeidsmarkt wil verblijven om bijvoorbeeld daarna kinderen te krijgen en te gaan verzorgen, zal de balans naar verwachting eerder uitslaan naar een direct aanbod op de arbeidsmarkt. Daarnaast is ook de huidige arbeidsmarktpositie van de zojuist afgesloten opleiding van belang. Als het momenteel moeilijk is om met een afgesloten opleiding een aantrekkelijke baan te vinden, zal men eerder geneigd zijn verder te leren.

Uit de in tabel 4.1 gepresenteerde resultaten blijkt dat vrouwen zich vaker na afloop van de studie op de arbeidsmarkt aanbieden ${ }^{18}$. Gemiddeld biedt $43 \%$ van de mannelijke schoolverlaters van 1993/'94 zich aan op de arbeidsmarkt. Als wordt gecorrigeerd voor het gemiddeld verschil tussen mannen en vrouwen wat betreft onder meer het gevolgde opleidingscluster, de etniciteit en de werkloosheid per opleiding dan blijkt precies de helft van de vrouwen zich aan te bieden op de arbeidsmarkt: een netto effect van +7 procentpunten. Schoolverlaters van Nederlandse afkomst gaan daarnaast vaker de arbeidsmarkt op dan allochtone schoolverlaters. Dit verschil tussen allochtonen en autochtonen is bovendien aanzienlijk groter dan het verschil tussen mannen en vrouwen. Uitgaand van de gemiddelde arbeidsmarktparticipatie van autochtone schoolverlaters van $42 \%$, komt de gecorrigeerde participatie van allochtonen op slechts $26 \%$ uit. Mogelijk hangt dit samen met een hogere gepercipieerde werkloosheidskans door allochtonen.

Naarmate de intredewerkloosheid bij een opleiding hoger is, besluiten minder schoolverlaters van de desbetreffende opleiding om zich aan te bieden op de arbeidsmarkt. Zoals reeds is gebleken uit de analyse van afgelopen jaar ${ }^{1 "}$ vluchten zij in het onderwijs. Als voor een opleiding het aandeel schoolverlaters dat langer dan drie maanden werkloos is, zou toenemen van het huidige gemiddelde van 15\% tot 20\%, dan zou dit betekenen dat de arbeidsmarktparticipatie afneemt van $41 \%$ tot $37 \% \%^{20}$. Dit effect is weliswat relatief vrij gering, maar in absolute aantallen gerekend gaat het daarbij toch om cen substantieel aantal schoolverlaters. Overigens blijkt dat vooral in West-Nederland de schoolverlaters vaker willen gaan werken. Wellicht wordt dit verschil met name veroorzaakt door de lagere werkloosheid in deze regio.

18 Zie voor een toelichting op de tabel het geelgekleurde kader op bladzijde 24

19 Zie M.S.M. van Smoorenburg en R.K.W. van der Velden, 1995, op chl.

20 Daarbij kan worden opgemerkt dat er wat dit betreft nauwelijks een verschil tussen mannen en vrouwen bestaat. 
Tabel 4.1

Netto effect van enkele factoren op de keuze van schoolverlaters om zich aan te bieden op de arbeidsmarkt (in procentpunten ten opzichte van het gemiddelde van de referentiegroep)

Verklarende

factoren

aanbieden op

de arbeidsmarkt

Opleidingscluster

MAVO

HAVO

WWO

VBO landbouw

VBO techniek

VBO economie

VB0 dienstverlening/verzorging

MBO-kort landbouw

MBO-kort techniek

MBO-kort economie

MBO-kort dienstverlening/verzorging

MBO landbouw

MBO techniek (referentiegroep)

MBO economie

MBO dienstverlening/verzorging

Woonregio

Noord

Oost

Zuid

Intredewerkloosheid langer dan drie maanden

Geslacht

Mannen (referentiegroep)

Vrouwen

Etniciteit

Autochtonen (referentiegroep)

Allochtonen

* = significant op $5 \%$-niveau

\subsection{Werkloosheid}

De werkloosheid onder gediplomeerde schoolverlaters van het AVO, VBO en de verschillende varianten van het MBO is tussen mei/juni 1994 en mei/juni 1995 licht gedaald van gemiddeld $8 \%$ naar 7\%. Deze daling doet zich vooral voor bij AVO- en VBO-schoolverlaters (zie figuur 4.1). Van de enkele schoolverlaters van het MAVO, HAVO of VWO die zich na hun opleiding aanbieden op de arbeidsmarkt was vorig jaar 15\% werkloos en dit jaar 10\%. Vooral HAVO-schoolverlaters blijken dit jaar erg vaak werkloos te zijn.

Van de VBO'ers die zich na het behalen van het diploma aanbieden op de arbeidsmarkt is na ongeveer een jaar $4 \%$ werkloos. Dit percentage ligt aanzienlijk lager dan het jaar 


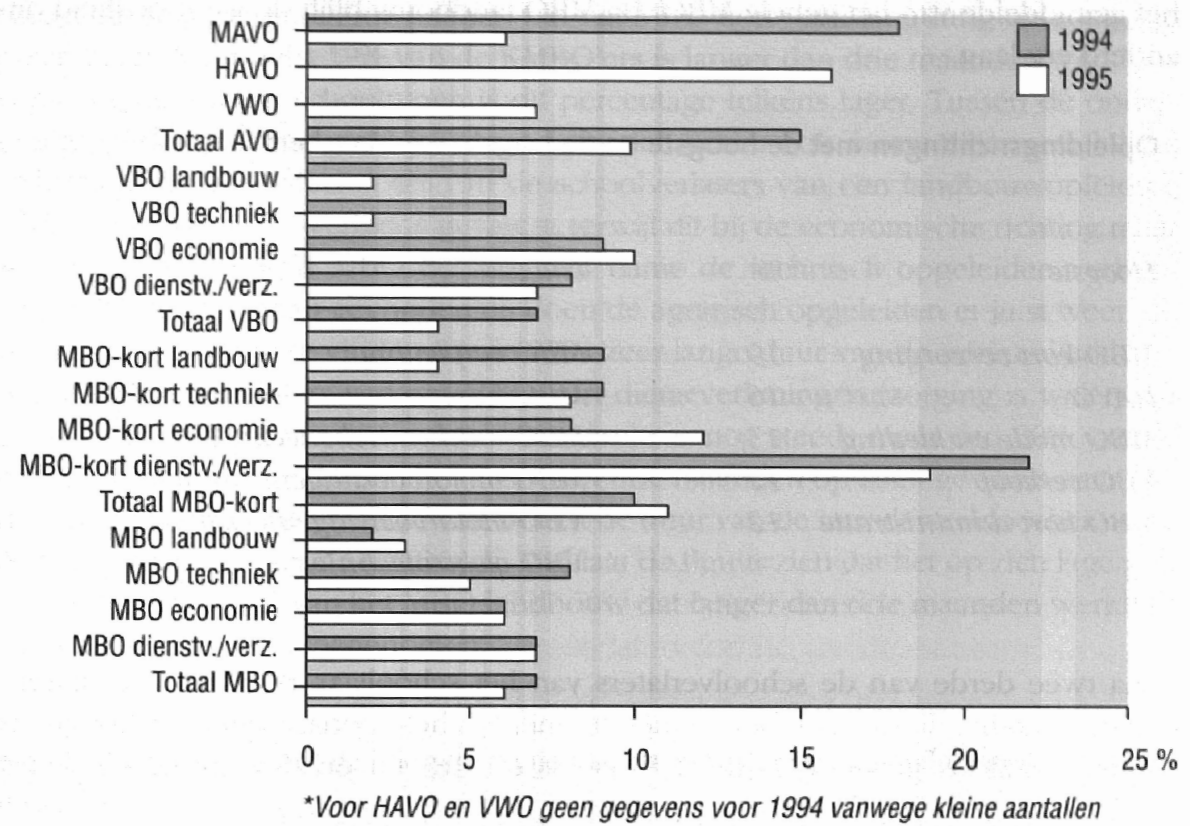

ervoor, hetgeen er op wijst dat de VBO'ers in ruime mate geprofiteerd hebben van de oplevende economie. Ook het feit dat vooral bij de conjunctururgevoelige opleiding VBO techniek de werkloosheid tussen 1994 en 1995 flink is gedaald tot nauwelijks 2\% wijst in die richting. Overigens is ook de werkloosheid onder schoolverlaters van het VBO landbouw afgenomen tot $2 \%$. Bij het opleidingscluster VBO dienstverlening/verzorging is er sprake van een slechts lichte daling van de werkloosheid. De werkloosheid blijft onveranderlijk hoog bij het opleidingscluster VBO economie. Vorig jaar was $9 \%$ van deze schoolverlaters werkloos; dit jaar is dit zelfs nog iets opgelopen tot $10 \%$.

Bij het MBO-kort ligt de werkloosheid al enkele jaren op een substantieel hoger peil. Onder de schoolverlaters van het schooljaar 1993/'94 bedraagt de werkloosheid een jaar na het verlaten van de opleiding gemiddeld $11 \%$, een lichte toename ten opzichte van vorig jaar. Net als vorig jaar steekt het opleidingscluster KMBO dienstverlening/verzorging fors boven dit gemiddelde uit. Zowel in 1994 als 1995 ligt het werkloosheidspercentage voor deze opleidingscategorie rond de $20 \%$. Bij het opleidingscluster KMBO landbouw is het werkloosheidspercentage tussen 1994 en 1995 meer dan gehalveerd. In 1994 was $9 \%$ van de schoolverlaters met deze opleidingsachtergrond werkloos en momenteel is dit nog slechts 4\%. Bij de korte MBO-opleiding in de economische richting is daarentegen de werkloosheid tussen 1994 en 1995 juist flink toegenomen, van 8\% tot 12\%.

Bij de schoolverlaters van een tussen of lange MBO-opleiding ligt het gemiddelde werkloosheidspercentage op $6 \%$. Vorig jaar was dit nog 7\%. Bij het opleidingscluster MBO 
techniek is sprake van een aanzienlijke verlaging van het werkloosheidspercentage van $8 \%$ in 1994 tot $5 \%$ in 1995 . Voor de andere MBO-opleidingsclusters is er nauwelijks enige verandering in het werkloosheidspercentage onder schoolverlaters. Voor de economische en dienstverlenende/verzorgende opleidingen ligt de werkloosheid rond het gemiddelde van het gehele MBO. Bij MBO landbouw blifft de werkloosheid onveranderd erg laag.

\section{Opleidingsrichtingen met de hoogste en de laagste werkloosheid}

$\begin{array}{llll}\text { Hoogste } & \% & \text { Laagste } & \% \\ \text { MBO-kort verzorging } & 19 & \text { MBO verpleging } & 0 \\ \text { HAVO } & 16 & \text { MBO boreca } & 0 \\ \text { MBO mode en kleding } & 13 & \text { MBO mechanische techniek } & 0 \\ \text { VBO verkoop } & 12 & \text { MBO motorvortuigentechniek } & 0 \\ \text { MBO-kort administratie } & 12 & \text { VBO motorvoertuigentechniek } & 0 \\ & & \text { VBO elektrotechniek } & 0\end{array}$

Bijna twee derde van de schoolverlaters van het schooljaar 1993/94, zijn tussen het behalen van het diploma en het enquêtemoment in het voorjaar van 1995 hooguit twee weken werkloos geweest. Ruim $20 \%$ is tussen de één en drie maanden werkloos

Figuur 4.2

Percentage schoolverlaters dat langer dan drie maanden werkloos is geweest per opleidingscluster, 1994 en $1995^{*}$

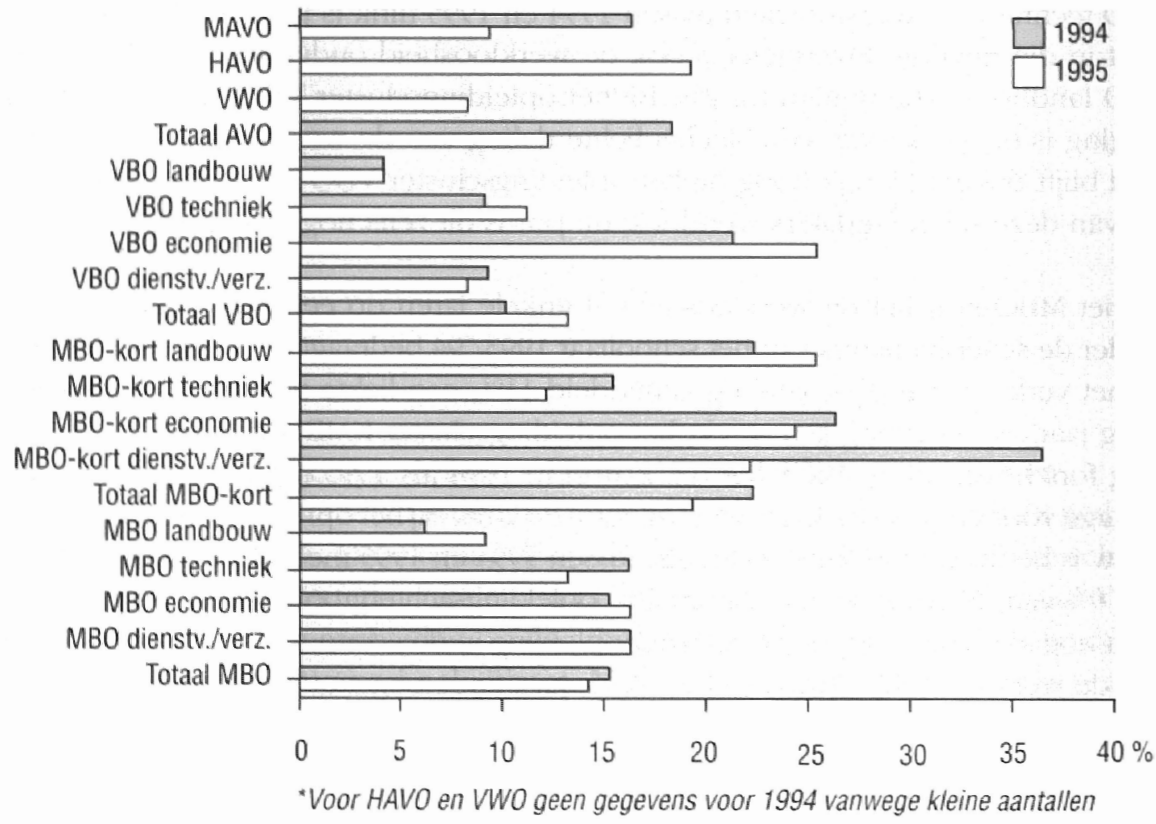


geweest, 9\% tussen de vier en zes maanden en 5\% is langer dan zes maanden werkloos geweest in deze onderzoeksperiode ${ }^{21}$. Figuur 4.2 geeft een overzicht van de verschillen tussen de opleidingsclusters in de duur van de intredewerkloosheid.

Het blijkt dat met name schoolverlaters van het MBO-kort vaak langdurig op zoek zijn naar een baan. Maar liefst 19\% van de KMBO'ers is langer dan drie maanden werkloos geweest. Bij de andere schooltypen is dit percentage telkens lager. Tussen de onderscheiden opleidingsrichtingen zijn er wat dit betreft echter ook aanzienlijke verschillen. Zo is binnen het VBO slechts $4 \%$ van de schoolverlaters van een landbouwopleiding meer dan drie maanden werkloos geweest, terwijl dit bij de economische richting maar liefst $25 \%$ is. Bij het kort MBO hebben met name de technisch opgeleiden verhoudingsgewijs snel een baan gevonden en doen de agrarisch opgeleiden er juist weer vrij lang over om een baan te vinden. De in 1994 zeer lange duur van de intredewerkloosheid onder schoolverlaters van het MBO-kort dienstverlening/verzorging is weliswaar in 1995 aanzienlijk afgenomen, maar desondanks is nog steeds meer dan 20\% van de schoolverlaters van deze opleiding langer dan drie maanden op zoek geweest naar een baan. Binnen het MBO bestaan ze wat betreft de duur van de intredewerkloosheid nauwelijks verschillen tussen de richtingen. Wel laat de figuur zien dat het op zich lage percentage schoolverlaters van het $\mathrm{MBO}$ landbouw dat langer dan drie maanden werkloos is geweest dit jaar iets is toegenomen.

\section{Opleidingsrichtingen met de hoogste en de laagste intredewerkloosheid van langer dan} 3 maanden

$\begin{array}{lllr}\text { Hoogste } & \% & \text { Laagste } & \% \\ & & & \\ \text { MBO-kort administratie } & 29 & \text { MBO motorvoertuigentechniek } & 0 \\ \text { MBO agogisch werk } & 25 & \text { MBO logistiek } & 2 \\ \text { MBO-kort landbouw } & 25 & \text { MBO plantenteelt } & 2 \\ \text { MBO dierenverzorging } & 21 & \text { MBO bloemschikken } & 3 \\ \text { MBO-kort verzorging } & 21 & & \end{array}$

Voorts is nagegaan welke factoren de kans om langer dan drie maanden werkloos te zijn beïnvloeden. Ook hierbij zijn de resultaten gepresenteerd in de vorm van de netlo effecten van de verschillende factoren (zie tabel 4.2). De tabel laat zien dat vooral allochtonen vaak langer werkloos zijn. Waar gemiddeld $13 \%$ van de autochtonen meer dan drie maanden op zoek is naar een baan, bedraagt dit voor een qua opleidingsachtergrond, geslacht, regio e.d. vergelijkbare groep allochtonen maar liefst $35 \%$. Om na te gaan wat de mogelijke oorzaken van dit grote verschil zijn, is gekeken of allochtonen vaker dan autochtonen tekortkomingen in de opleiding signaleren. Daarbij komt een aantal factoren naar voren die samenhangen met de beheersing van de Nederlandse taal: 'correcte spelling/foutloos schrijven', 'een verslag of rapport schrijven' en 'spreckvaardigheid'. Allochtonen blijken namelijk vaker méér aandacht te vragen voor deze drie aspecten. Zo blijkt bijvoorbeeld de helft van de allochtone schoolverlaters van het

21 Zie ook tabel 11 van de Kerngegerens 
Tabel 4.2

Netto effect van enkele factoren op de duur van de intredewerkloosheid van schoolverlaters (in procentpunten ten opzichte van het gemiddelde van de referentiegroep)

Verklarende
factoren
Opleidingscluster
MAVO
HAVO
WWO
VBO landbouw
VBO techniek
VBO economie
VBO dienstverlening/verzorging
MBO-kort landbouw
MBO-kort techniek
MBO-kort economie
MBO-kort dienstverlening/verzorging
MBO landbouw
MBO techniek (referentiegroep)
MBO economie
MBO dienstverlening/verzorging
Woonregio
Noord
Oost
Zuid
West (referentiegroep)
Geslacht
Mannen (referentiegroep)
Vrouwen
Etniciteit
Autochtonen (referentiegroep)
Allochtonen
* = significant op 5\% -niveau

intredewerkloosheid langer dan drie maanden

Opleidingscluster
MAVO
HAVO
WWO
VBO landbouw
VBO techniek
VBO economie
VBO dienstverlening/verzorging
MBO-kort landbouw
MBO-kort techniek
MBO-kort economie
MBO-kort dienstverlening/verzorging
MBO landbouw
MBO techniek (referentiegroep)
MBO economie
MBO dienstverlening/verzorging

Woonregio

Noord

MBO-kort van mening te zijn dat in de opleiding meer aandacht zou moeten worden besteed aan 'correcte spelling/foutloos schrijven'. Bij de autochtone schoolverlaters is slechts ongeveer een derde deze mening toegedaan. Dit resultaat is des te opvallender, daar van alle onderzochte onderdelen van het curriculum alleen bij deze aspecten nietNederlanders een duidelijk andere visie hebben.

Naast de etniciteit is ook het geslacht een bepalende factor bij de verklaring van een hogere intredewerkloosheid. Het effect is overigens wel beduidend geringer dan bij etniciteit. Vrouwen zijn vaker langer dan drie maanden werkloos dan mannen. Het netto effect bedraagt 4 procentpunten: van de mannen is gemiddeld 12\% langer dan drie maanden werkloos, terwijl dit percentage voor een voor de rest qua opleidingsachtergrond, etniciteit en woonregio identiek samengestelde groep vrouwelijke schoolverlaters op $16 \%$ ligt. Verder laat de tabel zien dat de duur van de intredewerkloosheid 
in het westen van het land gemiddeld iets korter is dan in de rest van het land. De verschillen zijn echter vrij gering.

Zoals ook in figuur 4.2 reeds is geconstateerd, is vooral ook de gevolgde opleiding een bepalende factor bij de mogelijkheid van schoolverlaters om snel een baan te vinden. Tabel 4.2 bevestigt het beeld dat vooral schoolverlaters van het kort MBO er doorgaans langer over doen om een baan te vinden. Ook de hoge werkloosheid onder schoolverlaters van het VBO economie en de juist korte intredewerkloosheid bij MBO landbouw kan niet volledig door de andere in de tabel opgenomen factoren worden verklaard en lijkt derhalve een duidelijk opleidingseffect.

\subsection{Beloning en benutting}

Het gemiddelde bruto uurloon ligt bij de tussen en lange opleidingen van het MBO duidelijk hoger dan bij de korte opleidingen van het MBO. Zowel AVO- als VBO-schoolverlaters verdienen gemiddeld gezien een stuk minder. Deze beloningsverschillen zijn overigens niet uitsluitend toe te schrijven aan het variërende opleidingsniveau, maar bijvoorbeeld ook aan het leeftijdsafhankelijke minimumjeugdloon ${ }^{22}$. Ook bínnen een bepaald opleidingsniveau - met een veelal vergelijkbare leeftijd van de schoolverlaters - bestaan er echter aanzienlijke beloningsverschillen tussen opleidingsclusters en opleidingsrichtingen. Figuur 4.4 geeft een naar opleidingscluster verbijzonderd overzicht van de bruto lonen die schoolverlaters gemiddeld per uur verdienen.

Indien de gemiddelde bruto uurlonen van de opleidingsrichtingen en -clusters in het $\mathrm{VBO} / \mathrm{AVO}$ worden afgezet tegen het gemiddelde bruto uurloon van deze opleidingen, dan kan worden vastgesteld dat de beloning bij de opleidingsclusters VBO dienstverlening/verzorging en MAVO als 'laag' en de beloning bij het HAVO als 'hoog' is te typeren. De beloning van de schoolverlaters van de opleidingsclusters VBO landbouw, VBO techniek en VBO economie ligt op een gemiddeld niveau, met slechts geringe onderlinge verschillen. Bij de vergelijking van de gemiddelde bruto uurlonen tussen de schoolverlaters van 1992/'93 en die van 1993/'94 valt op dat schoolverlaters van het VBO landbouw een betrekkelijk grote toename van de aanvangslonen hebben weten te realiseren. Daartegenover staat het opleidingscluster VBO techniek, waarbij het gemiddelde bruto uurloon licht is gedaald. Vorig jaar stak het VBO techniek nog af door een hoger bruto uurloon dan de andere VBO-opleidingen. Deze voorsprong is geheel verdwenen.

Schoolverlaters van de opleidingsclusters KMBO dienstverlening/verzorging en KMBO economie hebben een verhoudingsgewijs erg laag bruto uurloon. Bij de tussen en lange opleidingen van het MBO springt het MBO techniek er duidelijk in gunstige zin uit. Schoolverlaters van het opleidingscluster MBO techniek verdienen maar liefst $16 \%$ meer dan schoolverlaters van het MBO dienstverlening/verzorging, 17\% meer dan die van het $\mathrm{MBO}$ landbouw en zelfs $22 \%$ meer dan van schoolverlaters van het MBO economi $\mathrm{e}^{24}$.

22 Zie ook M.S.M. van Smoorenburg en R.K.W. van der Velden, 1995, op cil

23 Ter relativering dient te worden opgemerkt dat de gemiddelde leeftijd bij schoolverlaters van het MBO techniek ook één jaar hoger ligt, namelijk gemiddeld 22 i.p.v. 21 jaar. Fchter, oxk als wordi gecorrigeerd voor dit leeftijdseffect blijft een aanzienlijk verschil in beloning bestaan. 


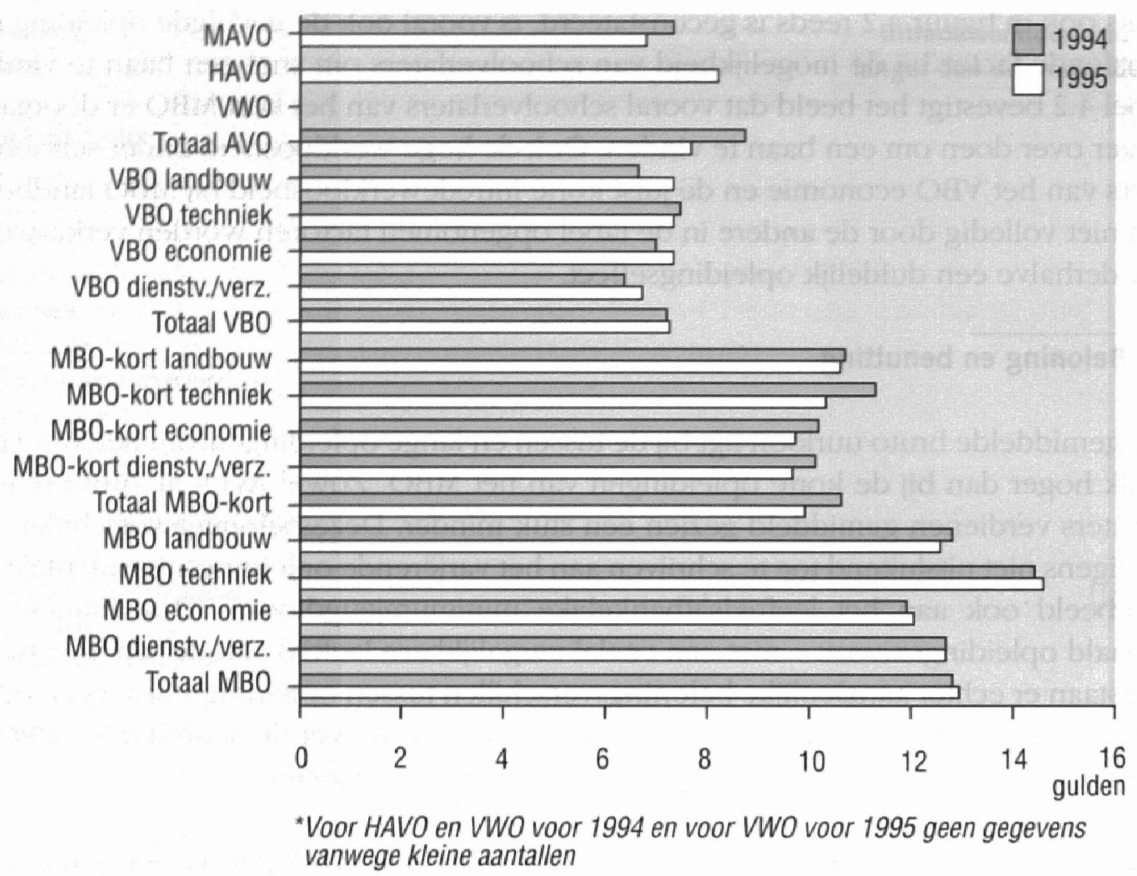

In figuur 4.4 is vervolgens voor 1994 en 1995 per opleidingscluster aangegeven welk deel van de schoolverlaters in hun kwalificaties wordt onderbenut. Er wordt gesproken over onderbenutting wanneer het vereiste opleidingsniveau voor de functie onder het genoten opleidingsniveau ligt. Dit is bijvoorbeeld het geval als een gediplomeerde MBO'er aangeeft dat voor de verkregen baan het KMBO-opleidingsniveau werd vereist of als bijvoorbeeld een gediplomeerde schoolverlater van het kort MBO stelt dat voor de uitoefening van de huidige functie een VBO-opleiding voldoende is. Overigens moet bij deze cijfers worden bedacht dat het hier gaat om intredefuncties. Eerdere analyses hebben aangetoond dat jongeren nogal eens via de bedrijfsinterne arbeidsmarkt doorstromen naar een baan die wel bij hun opleidingsniveau past ${ }^{24}$.

Ongeveer een derde van alle schoolverlaters is onder het gevolgde opleidingsniveau werkzaam. Dit is nagenoeg gelijk aan het de mate van onderbenutting van afgelopen jaar. De mutaties tussen 1994 en 1995 zijn in zijn algemeenheid, zowel naar schooltype als naar opleidingscluster, gering te noemen. Dit betekent dat nog steeds gediplomeerde KMBO'ers in iets meer dan de helft van de gevallen onder hun niveau werkzaam zijn. De figuur laat verder zien dat ongeveer een derde van de MBO- en AVO-schoolverla-

24 A. de Cirip. I.A.M. Heijke en E.J.T.A. Willems, Scholing en mobiliteit, Macmaschrift Economie. irg. 50. 1992. b1 $2.131-1+4$ 


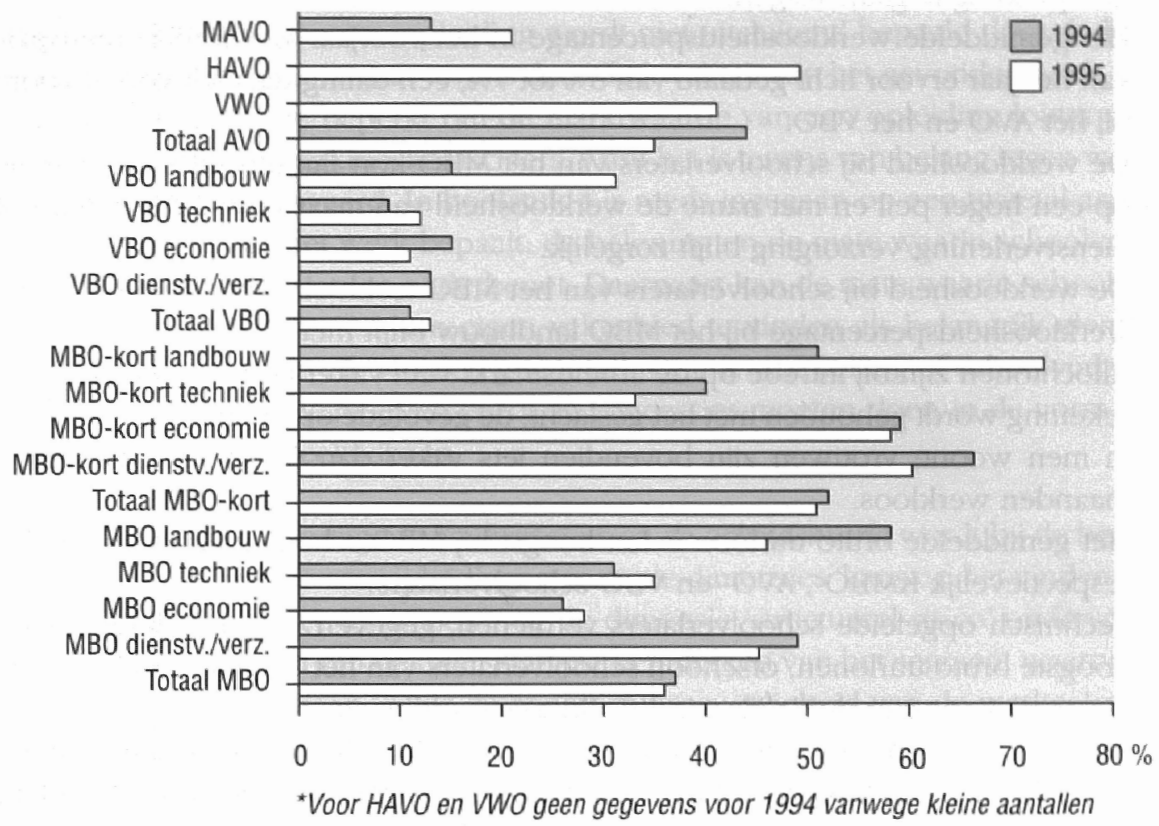

ters een baan onder hun niveau heeft en dat ruim 10\% van de VBO-schoolverlaters geen baan op VBO-niveau heeft weten te verwerven. Daarnaast geldt evenals in 1994 dat schoolverlaters van het $\mathrm{KMBO}$ techniek in vergelijking tot de overige KMBO-clusters een tamelijk laag onderbenuttingspercentage kennen en dat ook schoolverlaters van het $\mathrm{MBO}$ economie in vergelijking tot de overige $\mathrm{MBO}$-opleidingsclusters relaticf weinig onder hun opleidingsniveau werkzaam zijn.

Wel opvallend bij de vergelijking tussen de resultaten voor 1994 en 1995 is dat bij de landbouwopleidingen op zowel VBO- als KMBO-niveau de mate van onderbenutting flink is opgelopen, terwijl het onderbenuttingspercentage onder schoolverlaters van het MBO landbouw juist behoorlijk is gedaald. Bij de werkzame schoolverlaters van het VBO landbouw is het gedeelte dat ongeschoold werk heeft aanvaard zelfs verdubletd tot ruim $30 \%$. Van de schoolverlaters van het KMBO landbouw is momenteel maar liefst bijna driekwart onder hun niveau werkzaam. Ondanks de positieve ontwikkeling van het afgelopen jaar is nog steeds bijna de helft van de schoolverlaters van het MBO landbouw onder MBO-niveau werkzaam.

\subsection{Resumé}

De voornaamste conclusies over de arbeidsmarktintrede van schoolverlaters zijn:

- Vrouwelijke en autochtone schoolverlaters bieden zich vaker direct na het afsluiten van de opleiding aan op de arbeidsmarkt. 
- Naarmate het gemiddeld langer duurt voordat schoolverlaters van een opleiding een baan vinden, kiezen minder schoolverlaters er voor om met deze opleiding de arbeidsmarkt te betreden; zij wijken nogal eens uit door aansluitend een aanvullende opleiding te gaan volgen.

- Het gemiddelde werkloosheidspercentage in het voorjaar van 1995 is ten opzichte van het jaar ervoor licht gedaald van $8 \%$ tot $7 \%$, een daling die zich vooral voordoet bij het AVO en het VBO.

- De werkloosheid bij schoolverlaters van het MBO-kort ligt met $11 \%$ onveranderlijk op een hoger peil en met name de werkloosheid van maar liefst $22 \%$ bij het KMBO dienstverlening/verzorging blijft zorgelijk.

- De werkloosheid bij schoolverlaters van het MBO techniek is gedaald tot $5 \%$ en het werkloosheidspercentage bij het MBO landbouw blijft met 3\% laag.

- Allochtonen zijn bij intrede op de arbeidsmarkt veel vaker langer werkloos, ook als rekening wordt gehouden met het geslacht, de gevolgde opleiding en de regio waarin men woont; vrouwen zịn bovendien iets vaker dan mannen langer dan drie maanden werkloos.

- Het gemiddelde bruto uurloon is het hoogst bij $\mathrm{MBO}$-schoolverlaters gevolgd door respectievelijk KMBO-, AVO- en VBO-schoolverlaters.

- Technisch opgeleide schoolverlaters verdienen, gegeven het opleidingsniveau, de hoogste bruto uurlonen, ofschoon schoolverlaters van het VBO techniek in vergelijking met vorig jaar duidelijk minder zijn gaan verdienen.

- Net als bij de schoolverlaters van 1992/'93 is één van de drie werkzame schoolverlaters in een baan terechtgekomen waarvoor een opleiding werd vereist dat lager is dan het gevolgde opleidingsniveau. 


\section{De marktpositie van opleidingen}

De arbeidsmarktpositie van een opleiding wordt niet uitsluitend bepaald door de kans op het vinden van een baan, maar tevens door de kwaliteit van het gevonden werk. Het is met andere woorden te beperkt om de marktwaarde van een opleiding louter af te meten aan de hand van werkloosheidscijfers, want het is tevens van belang tegen welke 'prijs' een baan wordt aanvaard. In hoofstuk 4 is reeds ingegaan op een tweetal aspecten dat de kwaliteit van het werk bepaalt: de beloning en de mate waarin schoolverlaters in hun kwalificaties worden onderbenut. Daarnaast kan de mate waarin schoolverlaters erin slagen werk binnen hun eigen vakgebied te vinden als belangrijk element van de kwaliteit van het werk worden genoemd. Ook is van belang of schoolverlaters een vaste baan weten te verwerven en/of zij concessies moeten doen in de vorm van het accepteren van een deeltijdbaan.

Evenals in de vorige rapportage Schoolverlaters op de arbeidsmarkt wordt bij de beoordeling van de marktpositie van opleidingen naast de dimensies 'kans op het vinden van werk' en 'kwaliteit van het werk' ook nog de dimensie 'structureel risico' onderscheiden. Bij dit laatste gaat het om de meer stabiele kenmerken van het segment waarop de schoolverlaters zich bewegen, zoals de conjunctuurgevoeligheid van de werkgelegenheid of de mate waarin men erin slaagt om bij teruglopende werkgelegenheid in het 'eigen' segment uit te wijken naar andere arbeidsmarktsegmenten. In tabel 5.1 wordt een overzicht gegeven van de huidige marktpositie van de onderscheiden opleidingsclusters. Tevens is aangegeven hoe de kans op het vinden van werk en de kwaliteit van het gevonden werk zich sinds 1993 heeft ontwikkeld. Om het relatieve belang van deze cijfers weer te geven is tevens het percentage schoolverlaters dat zich aanbiedt op de arbeidsmarkt gepresenteerd.

\section{Algemeen Voortgezet Onderwijs}

Een kleine minderheid van schoolverlaters van het MAVO, HAVO en VWO kiest er voor om zich na afloop van de opleiding op de arbeidsmarkt aan te bieden. MAVO'ers en VWO'ers hebben in 1995 een goede kans op het vinden van een baan, terwijl HAVO'ers in 1995 juist veel moeite hebben om een baan te vinden. De werkloosheid onder HAVO'ers is in 1995 maar liefst 16\%.

De kwaliteit van het gevonden werk is voor MAVO- en HAVO-schoolverlaters slecht te noemen. Bij beide opleidingen is bijvoorbeeld het gemiddelde bruto uurloon laag en HAVO'ers zijn bovendien nogal eens onder hun niveau werkzaam. MAVO-schoolverlaters hebben overigens het voordeel dat ze in allerlei beroepsgroepen emplooi kunnen vinden, waardoor er sprake is van weinig structureel risico.

\section{Voorbereidend Beroeps Onderwijs}

Schoolverlaters van het VBO landbouw hebben een erg goede kans op het vinden van werk na afloop van hun opleiding. Bij het opleidingscluster VBO techniek is de kans op het vinden van werk ook zeker niet ongunstig en bovendien stabiel. De kans op het vin- 
Tabel 5.1

De arbeidsmarktpositie van schoolverlaters per opleidingscluster, 1995

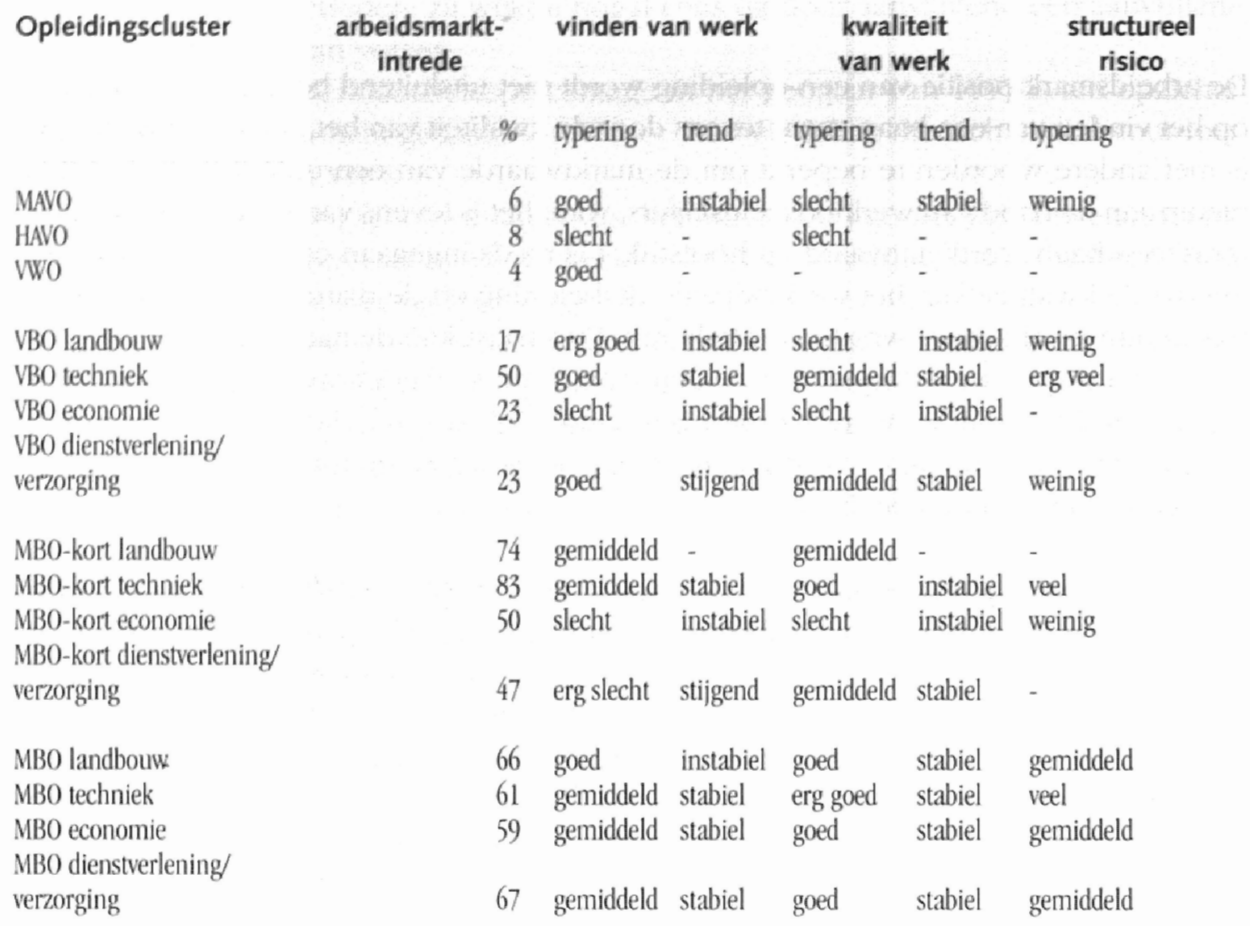

- = geen gegevens i.v.m. te weinig waarnemingen

den van een baan voor schoolverlaters van het VBO dienstverlening/verzorging is de afgelopen drie jaar, in vergelijking met andere opleidingsclusters, verbeterd. De mogelijkheden om een baan te vinden is momenteel voor deze opleiding zelfs goed te noemen. Daarentegen vinden schoolverlaters van het VBO economie duidelijk minder gemakkelijk een baan. Eén van de vier schoolverlaters van het VBO economie is na het verlaten van de opleiding tenminste drie maanden werkloos geweest en een klein jaar na schoolverlaten is nog circa $10 \%$ van de schoolverlaters van deze opleiding werkloos.

Ten opzichte van de gemiddelde kwaliteit van het door de schoolverlaters 1993/94 gevonden werk is de kwaliteit van het werk bij schoolverlaters van het VBO techniek en het VBO dienstverlening/verzorging te typeren als 'gemiddeld', terwijl schoolverlaters van het VBO landbouw en het VBO economie vaak in kwalitatief slechte banen terecht komen. De twee voornaamste redenen voor deze slechte kwaliteit van het werk bij het VBO landbouw zijn de geringe mate waarin schoolverlaters er in slagen om een vaste baan te vinden en het relatief grote deel van de schoolverlaters dat werkzaam is in functies walvoor het VBO/MAVO-niveau niet wordt vereist. Doordat weinig schoolverlaters van het $\mathrm{VBO}$ economie in hun eigen vakrichting terechtkomen en bovendien velen een part-time baan hebben, wordt de kwaliteit van het werk voor deze opleiding ook als slecht beoordeeld. Voor de landbouwrichting is wat dit betreft vooral het afge- 
lopen jaar een aanzienlijke verslechtering opgetreden, terwijl deze negatieve tendens voor het VBO economie met name tussen 1993 en 1994 is ingezet ${ }^{25}$.

Schoolverlaters van het VBO techniek hebben weliswaar een goede kans op het vinden van een baan en een gemiddelde kwaliteit van het gevonden werk, maar zij lopen bovendien - structureel gezien - een groter risico op de arbeidsmarkt. Zoals geldt voor alle technische richtingen, is ook de werkgelegenheid voor schoolverlaters van het VBO techniek erg gevoelig voor schommelingen in de conjunctuur. De opleidingen VBO landbouw en VBO dienstverlening/verzorging, hebben beide te maken met een gering structureel arbeidsmarktrisico. Zowel de conjunctuurgevoeligheid van de werkgelegenheid in de organisaties waarin deze schoolverlaters doorgaans terechtkomen als de mogelijkheden om uit te wijken naar andere beroepsgroepen zijn gunstig.

\section{De marktpositie van opleidingen}

De positie die schoolverlaters van een opleiding innemen - kortweg de marktpositie van die opleiding - wordt door drie dimensies bepaald. De kans op bet vinden van werk' is gebaseerd op bet werkloosheidspercentage op enquêtedatum en bet percentage schoolverlaters dat langer dan 3 maanden werkloos is geweest. De 'kwaliteit van bet werk' is opgebouwd uit viff indicatoren, namelijk gemiddeld bruto uurloon, bet percentage schoolverlaters met vast werk, bet percentage schoolverlaters dat wordt onderbenut, de mate waarin schoolverlaters in bun eigen vakrichting werk. vinden en ten slotte het percentage schoolverlaters dat een volledige aanstelling weet te verwerven. Het 'structureel risico' van een opleiding bestaat uit de conjunctuurgevoeligheid die indiceert hoe gevoelig de werkgelegenheid voor een opleidingscategorie is voor schommelingen in de economische ontwikkeling en de beroepsgroepenspreiding, die aangeeft wat de uitwijkmogelijkbeden van schoolverlaters naar andere beroepssegmenten zijn.

De marktpositie van een opleiding wordt uitgedrukt in een kwalitatieve typering voor elk van de dimensies, bijvoorbeeld: "een erg goede kans op bet vinden van werk, maar wel een gemiddeld genomen slechte kwaliteit van bet werk waar weer tegenover staat dat men structureel gezien weinig risico's op de arbeidsmarkt loopt". Deze typeringen zijn daarbij niet gebaseerd op een absolute maatstaf, maar bebben betrekking op de relatieve positie die de desbetreffende opleiding binnen bet scala van onderzochte opleidingsclusters inneemt.

Kort Middelbaar Beroeps Onderwijs

De kans op het vinden van werk is voor schoolverlaters van het KMBO economic en het KMBO dienstverlening/verzorging respectievelijk te typeren als 'slecht' en 'erg

25 Ook voor de toekomst zijn de arbeidsmarktperspectieven voor schoolverlaters van het VBO ceonomie naar verwachting ongunstig (zie ROA, De arbeidsmarkt naar opleiding on beroct w 2000 ). ROA-R-1995/3. Maastricht, 1995). 
slecht', Van de schoolverlaters van de korte MBO-opleiding in de economische richting is bijvoorbeeld $12 \%$ werkloos, terwijl de werkloosheid onder schoolverlaters van het KMBO dienstverlening/verzorging zelfs $19 \%$ bedraagt. De kans op het vinden van werk vertoont voor schoolverlaters van het KMBO dienstverlening/ver-zorging in vergelijking met 1993 en 1994 overigens wel een licht stijgende lijn: ten opzichte van de andere opleidingsclusters is de kans op het vinden van een baan voor deze schoolverlaters de afgelopen jaren iets verbeterd. De opleidingsclusters KMBO landbouw en KMBO techniek hebben een betere, namelijk een gemiddelde, kans op het vinden van werk.

Wat betreft de kwaliteit van het werk is er nogal wat variatie tussen de diverse opleidingsclusters van het kort MBO, zo blijkt uit tabel 5.1. Terwijl schoolverlaters van het KMBO techniek een goede kwaliteit van het werk weten te bewerkstelligen, is deze bij schoolverlaters van het KMBO landbouw en KMBO dienstverlening/verzorging gemiddeld en bij schoolverlaters van het KMBO economie zelfs slecht. De gunstige beoordeling van de kwaliteit van het werk voor schoolverlaters van een korte MBO-opleiding in de technische richting komt voornamelijk tot stand door de betrekkelijk goede aansluiting naar niveau en vakrichting tussen de aangeboden en de vereiste kwalificaties. Een erg groot gedeelte van de schoolverlaters van het KMBO techniek komt namelijk in een functie terecht waarvoor de eigen vakrichting vereist is en het aandeel schoolverlaters dat terechtkomt in een baan onder KMBO-niveau is niet groter dan gemiddeld. Dit laatste gegeven is des te opmerkelijker aangezien in zijn algemeenheid zeer veel KMBO'ers een baan onder hun eigen opleidingsniveau (moeten) accepteren. De slechte kwaliteit van het werk van schoolverlaters van een korte MBO opleiding economie komt onder meer tot uitdrukking in relatief laag percentage werkenden met een vaste baan. Daarnaast is de aansluiting van de opleiding met de baan zowel wat betreft niveau als vakrichting ronduit slecht te noemen. Zes van de tien schoolverlaters van het KMBO economie komt namelijk in een baan terecht die onder het eigen opleidingsniveau ligt en slechts een kwart vindt een baan waarvoor de eigen vakrichting vereist is. Daar staat tegenover dat het structureel risico op de arbeidsmarkt voor schoolverlaters van het KMBO economie gering is. Voor zover zij in een baan terechtkomen waarvoor tenminste het eigen opleidingsniveau is vereist, is de mate van spreiding over verschillende beroepsgroepen groot. Dit kan worden gezien als een bredere mogelijkheid om uit te wijken naar andere beroepssegmenten en dus als een indicatie van een laag structureel arbeidsmarktrisico. De uitwijkmogelijkheden voor schoolverlaters van het KMBO techniek zijn laag. Te zamen met de hoge gevoeligheid voor schommelingen in de werkgelegenheid, levert dit een hoog risico op voor schoolverlaters van het KMBO techniek.

\section{Middelbaar Beroeps Onderwijs}

Voor de schoolverlaters van het $\mathrm{MBO}$ is de kans op het vinden van een baan meestal gemiddeld en in het geval van het MBO landbouw zelfs goed. Slechts $3 \%$ van de schoolverlaters van het MBO landbouw is in 1995 werkloos. Bij de overige MBO-opleidingsclusters is de werkloosheid weliswar iets hoger, maar zeker niet ongunstig. Bovendien is de kans op het vinden van een baan voor schoolverlaters van het MBO techniek, het $\mathrm{MBO}$ economie en het MBO dienstverlening/verzorging te typeren als stabiel. Er hebben zich de afgelopen drie jaren betrekkelijk weinig schommelingen in hun werkloosheidskansen voorgedaan. 
In vergelijking met de overige schooltypen is de kwaliteit van het werk bij MBO-schoolverlaters 'goed' tot 'erg goed'. Bij alle vier de opleidingsclusters is er tevens al enkele jaren sprake van een gunstige situatie. MBO'ers verdienen een hoger loon, hebben vaker vast werk, zijn vaker in hun eigen vakrichting werkzaam en vervullen ook vaker een full-time functie. Op vrijwel alle elementen die de kwaliteit van het werk bepalen neemt het MBO techniek een zeer gunstige positie in.

Tegenover de gemiddelde kans op het vinden van werk en de erg goede kwaliteit van het werk bij schoolverlaters van het MBO techniek staat echter wel een structureel hoger risico op de arbeidsmarkt. Zo komen schoolverlaters van het $\mathrm{MBO}$ techniek veelal terecht in sectoren die onderhevig zijn aan sterke schommelingen in de werkgelegenheid. Bij de overige opleidingsclusters op MBO-niveau, landbouw, economie en dienstverlening/verzorging, is het structureel risico vergelijkbaar met het gemiddelde van alle opleidingsclusters. Schoolverlaters van het $\mathrm{MBO}$ economie hebben met name goede mogelijkheden om in allerlei beroepsgroepen werkzaam te zijn. Dit voorkomt dat men te afhankelijk is van een specifiek beroep. Schoolverlaters van de MBO-opleidingen in de dienstverlenende/verzorgende richtingen komen vooral in de weinig conjunctuurgevoelige zorgsector terecht.

\section{Resumé}

De belangrijkste conclusies betreffende de arbeidsmarktpositie van opleidingen zijn als volgt:

- Ondanks het feit dat de kans op het vinden van werk voor schoolverlaters van het MBO-kort dienstverlening/verzorging de afgelopen drie jaar is verbeterd, is deze nog steeds erg slecht.

- Schoolverlaters van het KMBO economie, het VBO economie en het HAVO hebben in 1995 veel moeite met het vinden van werk.

- Schoolverlaters met een agrarische beroepsopleiding hebben een gemiddelde tot erg goede kans op het vinden van werk.

- De kwaliteit van het gevonden werk is bij MBO-schoolverlaters de afgelopen dric jaar te typeren als goed tot zeer goed.

- In vergelijking tot de overige opleidingsclusters binnen hetzelfde niveau, leidt technisch beroepsonderwijs tot een gunstige kwaliteit van het werk. Daar staat echter tegenover dat er tevens sprake is van een hoog structureel risico, vanwege het feit dat technisch opgeleiden veelal in sectoren terechtkomen die worden geconfronteerd met een hoge mate van conjunctuurgevoeligheid. Ook hebben technisch opgeleide schoolverlaters minder mogelijkheden om uit te wijken naar andere beroepen of bedrijven ${ }^{26}$.

26 Overigens nemen deze uitwijkmogelijkheden in de loop van de carrière toe. Technisch opgelei den die reeds langer werkzaam zijn hebben juist veel uitwijkmogelijkheden op de arlyeidsmarkı. Zie ROA, 1995, op cit. en L. Borghans, A. de Grip en W. Smits, Beroepsmobiliteit tan techuisch opgeleiden, OSA D1, Den Haag, 1995. 
Schopicieriateres 


\section{De flexibilisering van de arbeidsmarkt}

\subsection{Inleiding}

De werkloosheid in Nederland is in de jaren ' 70 en ' 80 fors toegenomen en is in de jaren 90 op dit hoge niveau blijven liggen. Ook de werkloosheid onder jongeren bevindt zich al jaren op een hoog niveau ${ }^{2 \tau}$. De in de dit rapport gepresenteerde resultaten laten eveneens zien dat een deel van de schoolverlaters er niet in slaagt een baan te vinden. Als oorzaak van deze problematiek wordt nogal eens de starheid en regulering van de arbeidsmarkt gezien. Met name de laatste jaren is er een sterk toenemende roep om een vergaande flexibilisering van de arbeidsmarkt. Vooral vanuit werkgeverskringen wordt frequent benadrukt dat een flexibel personeelsbestand noodzakelijk is om het hoofd te bieden aan de internationale concurrentie. Ook door de veranderende wensen van de consument (bv. ruimere openingstijden) zou een flexibel opererende arbeidsmarkt noodzakelijk zijn.

Zoals tevens is verwoord in de recente nota Flexibiliteit en zekerbeid van het Ministerie van Sociale Zaken en Werkgelegenheid (1995) treedt er wat dit betreft een duidelijk spanningsveld op. Werknemers zullen immers doorgaans minder prijs stellen op flexibelere dienstverbanden, aangezien hierdoor hun werkzekerheid en daarmee hun inkomenszekerheid ernstig wordt aangetast. Zeker naarmate men ouder word, zullen arbeidskrachten meer aan dergelijke zekerheden gaan hechten. Het ligt daarom voor de hand dat vooral jongeren, en dan met name schoolverlaters, in eerste instantie voor deze flexibilisering van de arbeidsmarkt zorg moeten gaan dragen.

In dit hoofdstuk wordt achtereenvolgens ingegaan op verschillende manieren waarop de arbeidsmarktflexibiliteit vorm kan krijgen. Eerst wordt daarbij in paragraaf 6.2 een overzicht gegeven van de diverse vormen van flexibele dienstverbanden, zoals uitzendwerk en oproep- en nulurencontracten. Bijna één op de tien werknemers in Nederland heeft een flexibele baan ${ }^{2 *}$. Daarnaast blijkt uit cijfers van het CBS dat bijna de helft van alle uitzendkrachten jonger is dan 25 jaar $^{29}$. Nagegaan zal worden in hoeverre deze en andere vormen van flexibele arbeid door schoolverlaters van de verscheidene opleidingsclusters worden uitgeoefend. Tevens worden de branches eruit gelicht die relatief vaak van flexibele arbeid gebruik maken. Bovendien wordt nagegaan of een hoge werkloosheid bij een opleiding samengaat met een hoger aandeel schoolverlaters dat een flexibele arbeidsrelatie heeft. Schoolverlaters zijn in dat geval genoodzaakt om een prijs te betalen voor hun slechtere kans op het vinden van werk.

Een andere manier om een meer flexibele arbeidsmarkt te bewerkstelligen is door de beschikbare hoeveelheid werk over meer arbeidskrachten te verdelen. Dergelijke decl-

\footnotetext{
27 J. de Koning, Jeugdwerkloosheid: een blijvend probleem, Economisch Statistische Berichten, irg. 81, nr. 4046, 21 februari 1996, blz. 173-175.

28 ROA. 1995. op cit.

29 Centraal Bureau voor de Statistiek, Werken en leren in Nederland 1995, CBS, Voorburg, 1995
} 
tijdarbeid biedt meer mogelijkheden om eventuele pieken in de werkgelegenheid op te vangen. International gezien wordt in Nederland enorm veel in part-time functies gewerkt. Als rekening wordt gehouden met enkele karakteristieken van de arbeidsmarkt, zoals de arbeidsparticipatie van vrouwen en de verdeling van de werkgelegenheid over beroepsgroepen, blijkt dat van de negen onderzochte landen van de Europese Unie Nederland het hoogste aandeel part-timers heeft ${ }^{30}$. Werken schoolverlaters ook vaak in deeltijdbanen en zijn vrouwen reeds bij de eerste stappen op de arbeidsmarkt oververtegenwoordigd in part-time functies? Deze en andere vragen zullen worden beantwoord in paragraaf 6.3.

Tot slot wordt in paragraaf 6.4 een geheel andere vorm van arbeidsmarktflexibiliteit belicht: de mate waarin schoolverlaters in de eerste jaren van hun loopbaan van baan wisselen. Hiermee wordt aangegeven hoe sterk jongeren gebonden zijn aan één bepaald bedrijf. Dit hoeft overigens niet altijd te wijzen op een gewenste flexibele situatie. Indien de baan die schoolverlaters hebben niet goed aansluit bij hun opleiding zullen zij mogelijk eerder geneigd zijn om te zien naar een andere werkkring. Uit eerdere onderzoeken is reeds vaak gebleken dat mobiliteit vooral bij jongeren voorkomt, niet alleen omdat zij vaker nog op zoek zijn naar de juiste baan, maar ook omdat het voor jongeren vaker lonend is om van baan te wisselen, met name omdat zij nog minder bedrijfsspecifieke kennis hebben opgebouwd. Zo blijkt bijvoorbeeld uit een onderzoek van Topel en Ward ${ }^{31}$ dat in de eerste tien jaar van hun loopbaan Amerikaanse nieuwkomers op de arbeidsmarkt gemiddeld maar liefst zeven banen hebben gehad. Ook in Nederland verricht onderzoek, met name in opdracht van de Organisatie voor Strategisch Arbeidsmarktonderzoek (OSA), laat zien dat vooral jongeren mobiel zijn. Zo heeft ongeveer twee derde van alle baanmobiliteit betrekking op werkenden in de leeftijd van 15-30 jaar, terwijl deze leeftijdscategorie slechts een derde van de beroepsbevolking uitmaakt ${ }^{32}$

Overigens moet worden opgemerkt dat de flexibilisering van de arbeidsmarkt niet uitsluitend in de drie hiergenoemde kenmerken (flexibele arbeidsrelaties, part-time werk en intredemobiliteit) tot uitdrukking hoeft te komen. Ook binnen bestaande vaste en full-time arbeidsrelaties kan er sprake zijn van een toenemende flexibilisering. Voorbeelden daarvan zijn 'job rotation' programma's e.d. waarbij werkenden binnen een bedrijf na enkele jaren van functie veranderen.

\subsection{Flexibele arbeidsrelaties}

Van de werkende schoolverlaters is slechts iets meer dan de helft in loondienst bij een

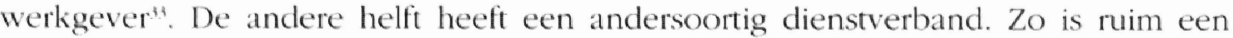
kwart werkzaam op basis van een leer-werk-overeenkomst. Daarnaast werkt ruim $10 \%$ via een uitzendbureau en heeft $4 \%$ van de schoolverlaters een contract als oproep-

30 A. de Grip, J. Hoevenberg. E. Willems, Atypical employment relations by occupational sector in the European Union, ROA-RM-19995/5E, Maastricht, 1995.

31 R.H. Topel en M.P. Ward, Job mobility and the careers of young men. NBER. 1988.

32 E.W. Mekkelholt, Een sequentiele analyse tan de baanmobiliteit in Nederland. Universiteit van Amsterdam. 1993.

33 Zie Kerngegetens, tabel 18 
Figuur 6.1

Percentage schoolverlaters met uitzendwerk en oproep- of nul-urencontract per opleidingscluster, 1994 en 1995*

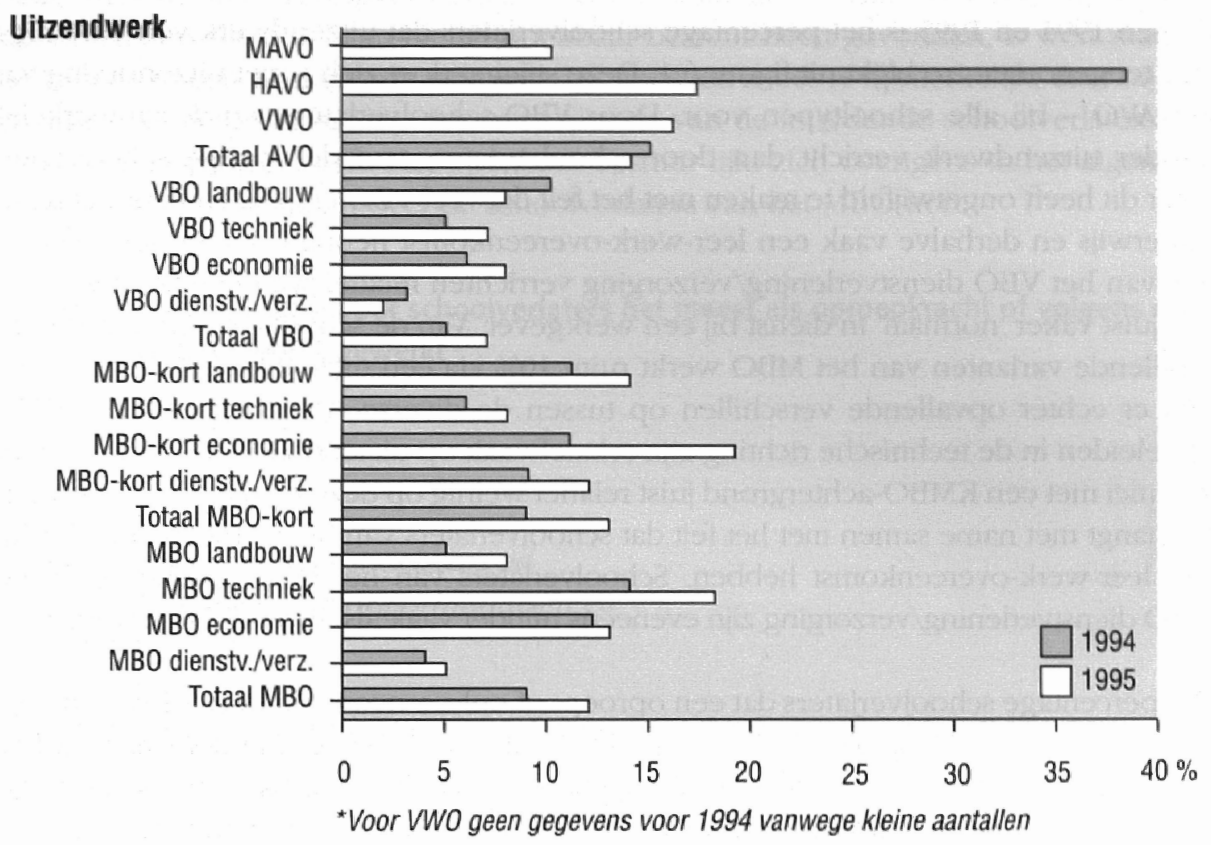

\section{Oproep- of nul-urencontract}

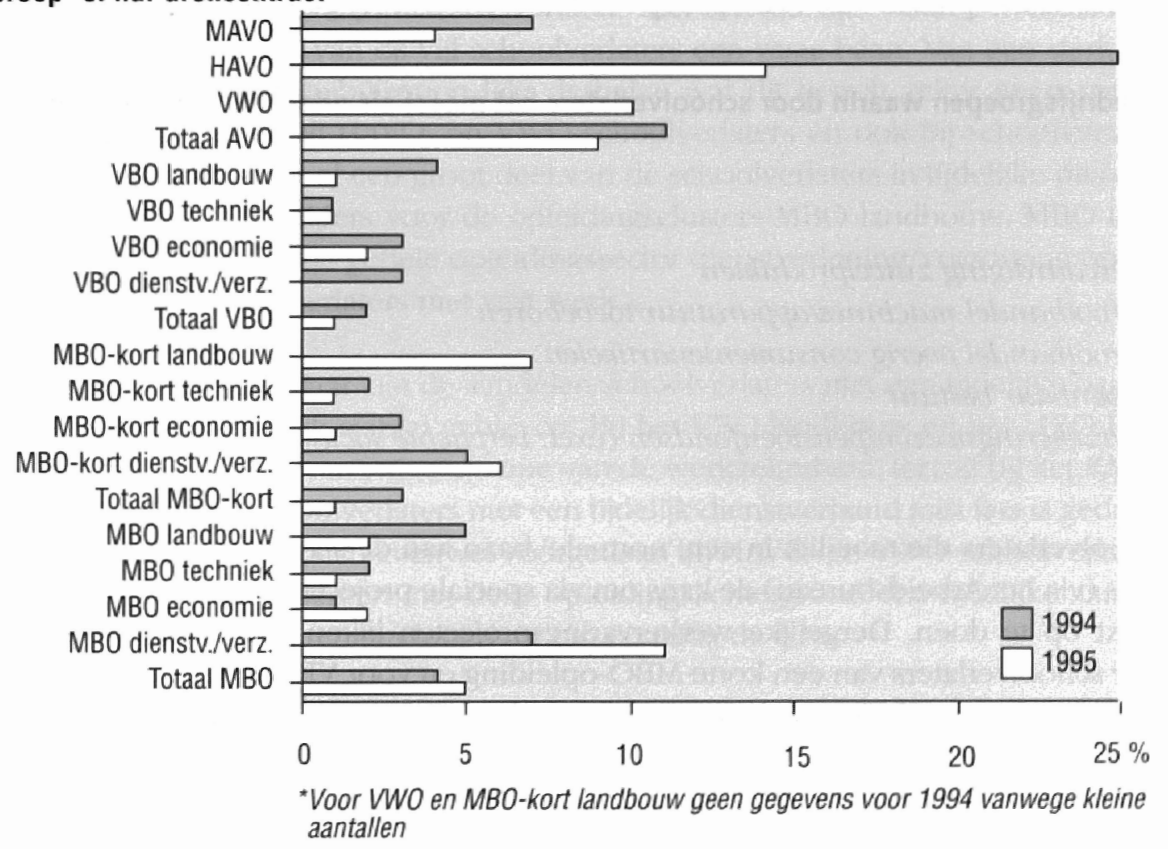


kracht. Slechts een gering aandeel van de schoolverlaters is werkzaam in een werkervaringsproject. Het aantal schoolverlaters dat een eigen bedrijf is gestart of in het bedrijf van de ouders/partners meewerkt is eveneens beperkt.

Tussen 1994 en 1995 is het percentage schoolverlaters dat uitzendwerk verricht enigszins toegenomen, zo blijkt uit figuur 6.1. Deze stijging doet zich - met uitzondering van het AVO - bij alle schooltypen voor. Door VBO-schoolverlaters wordt aanmerkelijk minder uitzendwerk verricht dan door schoolverlaters van de overige schooltypen, maar dit heeft ongetwijfeld te maken met het feit dat veel VBO'ers kiezen voor het duaal onderwijs en derhalve vaak een leer-werk-overeenkomst hebben. Vooral schoolverlaters van het VBO dienstverlening/verzorging verrichten relatief weinig uitzendwerk en zijn juist vaker 'normaal' in dienst bij een werkgever. Van de schoolverlaters van de verschillende varianten van het $\mathrm{MBO}$ werkt ruim $10 \%$ via een uitzendbureau. Daarbij treden er echter opvallende verschillen op tussen de diverse opleidingsclusters. MBOopgeleiden in de technische richting zijn relatief vaak op uitzendbasis wekzaam, terwijl technici met een KMBO-achtergrond juist relatief weinig op deze manier werkzaam zijn. Dit hangt met name samen met het feit dat schoolverlaters van het KMBO techniek vaak een leer-werk-overeenkomst hebben. Schoolverlaters van het MBO landbouw en het MBO dienstverlening/verzorging zijn eveneens minder vaak als uitzendkracht werkzaam.

Het percentage schoolverlaters dat een oproep- of nul-urencontract heeft, is tussen 1994 en 1995 exact gelijk gebleven. Daarbij valt op dat AVO- en in mindere mate MBOschoolverlaters het vaakst op basis van een dergelijk dienstverband werkzaam zijn. Vooral HAVO'ers en schoolverlaters van het MBO dienstverlening/verzorging hebben nogal eens een oproep- of nul-urencontract. Bij het VBO en het MBO-kort was het aandeel oproepkrachten in 1994 al erg laag en in 1995 is dit zelfs nog verder gedaald. Alleen bij de korte MBO-opleidingen landbouw en dienstverlening/verzorging wordt relatief vaak op basis van een oproep- of nul-urencontract gewerkt.

\section{Bedrijfsgroepen waarin door schoolverlaters het meest als uitzendkracht wordt gewerkt}

$\begin{array}{lc} & \% \\ \text { Vervaardiging zuivelprodukten } & 61 \\ \text { Groothandel machines/apparatuur/toebehoren } & 37 \\ \text { Groothandel overig consumentenartikelen } & 32 \\ \text { Openbaar bestuur } & 29 \\ \text { Verzekeringswezen/pensioenfondsen (excl. verplichte saciale verzekeringen) } & 26\end{array}$

Schoolverlaters die moeilijk in een 'normale' baan aan de slag kunnen komen, krijgen soms (via het Arbeidsbureau) de kans om via speciale projecten ervaring op de arbeidsmarkt op te doen. Dergelijke werkervaringsprojecten lijken met name voorbestemd voor schoolverlaters van een korte MBO-opleiding en voor VBO'ers in de sectoren economie en dienstverlening/verzorging ${ }^{3+}$. Het wekt weinig verbazing dat dit juist de oplei-

34 Zie Kerngegerens, tabel 18. 
dingen zijn, waarbij de kans op het vinden van een baan als slecht is getypeerd. Schoolverlaters van alle overige opleidingsclusters komen zelden in een werkervaringsproject terecht. Opvallend is dat het openbaar bestuur veruit de belangrijkste aanbieder van werkervaringsplaatsen voor schoolverlaters is. Maar liefst één van de drie schoolverlaters die een baan bij het openbaar bestuur heeft gevonden, is werkzaam in het kader van een werkervaringsproject. Dit gegeven is des te opmerkelijk, daar bij vrijwel alle overige bedrijfsgroepen nauwelijks $1 \%$ van de intredende schoolverlaters een werkervaringsproject heeft. Het openbaar bestuur lijkt zich overigens in het algemeen bij uitstek te bekommeren over de schoolverlaters van het MBO-kort.

\section{Bedrijfsgroepen waarin door schoolverlaters het meest als oproepkracht of volgens een nul-urencontract wordt gewerkt}

$\begin{array}{lr}\text { Welzijnszorg } & 15 \\ \text { Restaurants/cafetaria's/snackbars ed } & 11 \\ \text { Reiniging gebouwen/transportmiddelen ed } & 9 \\ \text { Reklamebureaus ed } & 8 \\ \text { Gezondheidszorg } & 8 \\ \text { Reisorganisatie/-bemiddeling,;informatieverstrekking op gebied toerisme } & 8\end{array}$

Niet alleen door het soort dienstverband maar ook door een kortere duurvan de aanstelling kan een flexibilisering van de arbeidsmarkt worden bereikt. Het is daarom van belang een verder onderscheid te maken tussen schoolverlaters met een vaste baan (of proeftijd voor een vaste baan) en schoolverlaters met een tijdelijke baan ${ }^{35}$. Evenals vorig jaar heeft gemiddeld drie van de vijf schoolverlaters een vaste baan. Van een sterk toenemende arbeidsmarktflexibilisering lijkt derhalve wat dit betreft zeker geen sprake. Figuur 6.2 laat zien dat bij HAVO- en VWO-schoolverlaters en ook bij schoolverlaters van het VBO landbouw wel een groot deel van de schoolverlaters in tijdelijke dienst is. Daarentegen wijzen de cijfers voor de opleidingsclusters MBO landbouw, MBO techniek, MBO economie en de gehele opleidingssector dienstverlening/verzorging op een hoog percentage schoolverlaters met vast werk.

In vergelijking met vorig jaar zijn de aandelen schoolverlaters met een tijdelijke haan in zijn algemeenheid tamelijk stabiel gebleven. Bij het VBO landbouw en het MBO landbouw is er echter sprake van enige afname van de werkzekerheid, terwijl bij het KMBO techniek het aandeel schoolverlaters met een tijdelijk dienstverband juist iets is gedaald. De grootste afname heeft zich evenwel voorgedaan bij HAVO- en VWO-schoolverlaters Vorig jaar had vrijwel iedereen met deze opleidingsachtergrond een tijdelijke aanstelling, terwijl dit in 1995 is teruggelopen tot om en nabij de $60 \%$.

Figuur 6.3 geeft een samenvattend overzicht van het deel van de schoolverlaters dat een

35 Schoolverlaters die een eigen hedriff hehben of werkzam zijn in het bedrijf van de ouders/partner worden hierbij buiten beschouwing gelaten. 


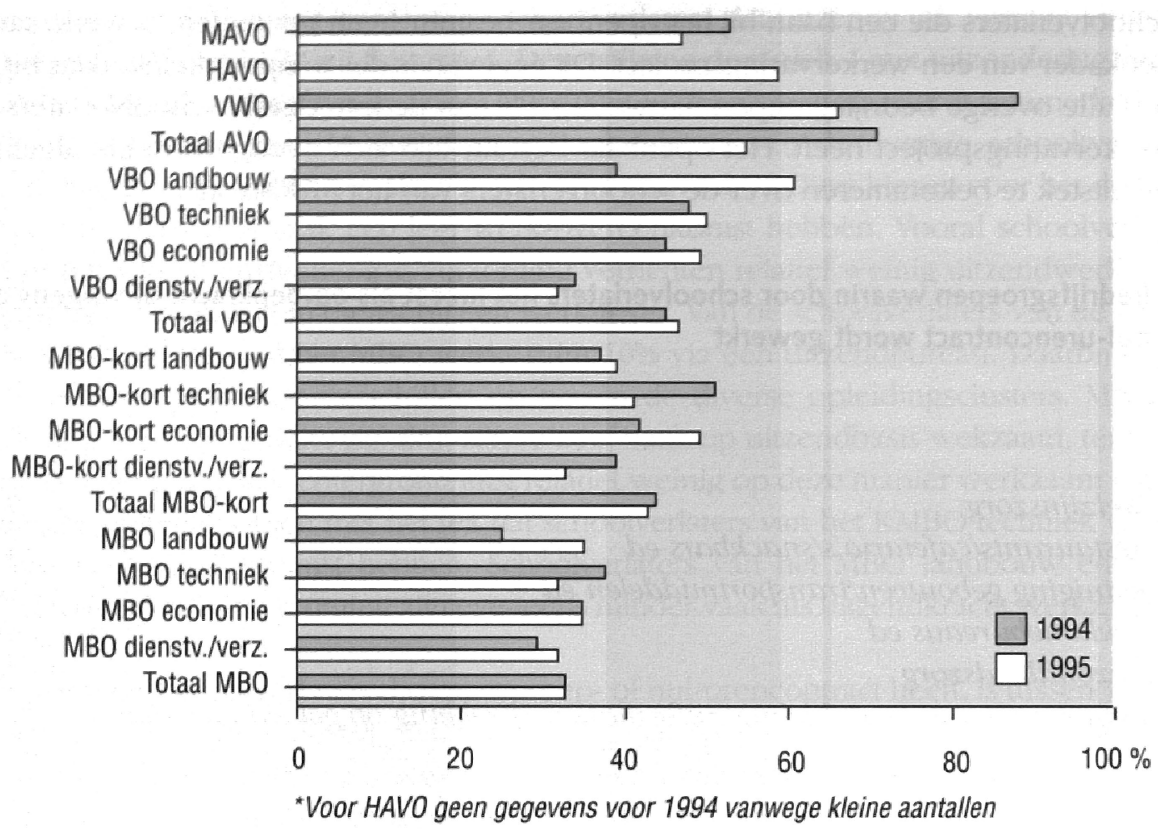

flexibele arbeidsrelatie heeft aanvaard. Daarbij wordt gesproken van een flexibele arbeidsrelatie als er sprake is van uitzendwerk, een oproep- of nul-urencontract of een werkervaringsproject, maar ook indien een schoolverlater in loondienst of op basis van een leer-werk-overeenkomst werkzaam is met een contract van maximaal een half jaar. Volgens deze afbakening blijkt dat gemiddeld $22 \%$ van de werkende schoolverlaters een klein jaar na het verlaten van de opleiding een flexibele arbeidsrelatie heeft. Bij AVO-schoolverlaters is het percentage flexwerkers ruim boven dit gemiddelde. VBOschoolverlaters hebben juist iets minder vaak een flexibel arbeidscontract. Zoals reeds eerder is geconstateerd, hebben vooral HAVO- en VWO-schoolverlaters verhoudingsgewijs vaak een flexibele arbeidsrelatie. VBO'ers met een opleiding in de dienstverlening/verzorging of in de techniek werken erg weinig op flexibele basis. Hetzelfde geldt voor schoolverlaters van het kort MBO in de technische richting. Binnen het kort MBO werken vooral de agrarische en de dienstverlenend/verzorgend opgeleiden in een flexibel dienstverband.

Een opvallend resultaat van een aanvullende analyse is dat vrouwelijke schoolverlaters significant minder vaak een flexibele arbeidsrelatie aangaan dan mannen. Het gemiddelde percentage schoolverlaters met een flexibele arbeidsrelatie bedraagt bij mannen $21 \%$. Tabel 6.1 laat zien dat bij een - qua opleidingsachtergrond, etniciteit en bedrijfssector wararin men werkzaam is - vergelijkbare groep vrouwen dit percentage flexibele 


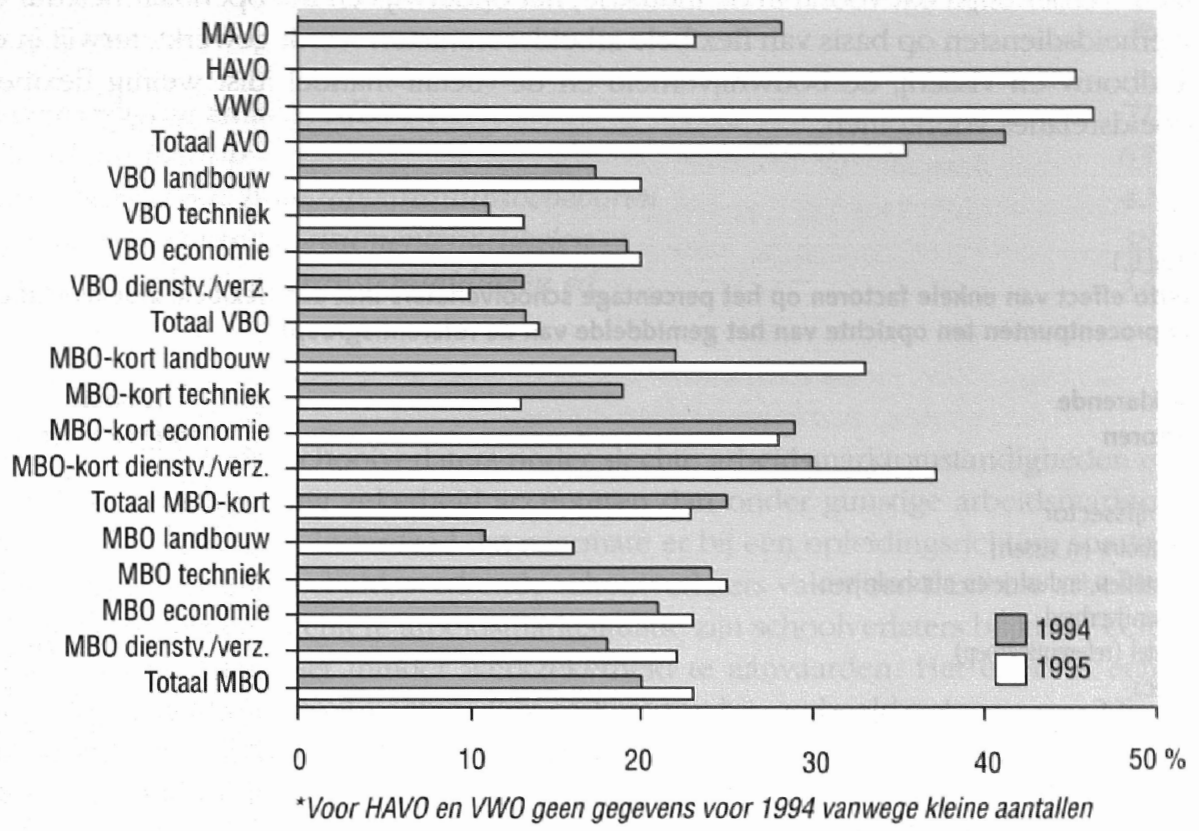

arbeidskrachten $17 \%$ bedraagt: een netto verschil van -4 procentpunten ${ }^{36}$. De verschillen tussen allochtonen en autochtonen wat betreft het aangaan van flexibele arbeidsrelaties zijn evenwel groter. Allochtonen hebben veel vaker een flexibele arbeidsrelatie dan autochtonen, zodat er bij hen sprake is van een geringere mate van werkzekerheid. Dit zou een reflectie kunnen zijn van de slechte kans op het vinden van werk voor allochtonen, waardoor zij eerder genoodzaakt zijn om een baan van slechtere kwaliteit te aanvaarden.

Bedrijfsgroepen waarin door schoolverlaters het meest op basis van een werkervaringsproject wordt gewerkt

36 Zie het geelgekleurd kader op bladzijde 24 voor een toelichting op de berekening van dergetijke netto effecten. De opleidingseffecten zijn vanwege de overzichtelijkheid hier niet gepresenteerd. 
Flexibele arbeidsrelaties blijken met name geconcentreerd te zijn in de grotere organisaties. Kleine bedrijven of instellingen werken veel minder vaak met flexibele arbeidskrachten. Naarmate het bedijf groter is, wordt vaker een flexibele arbeidsrelatie aangegaan. Verder blijkt dat vooral in de industrie, het onderwijs en het openbaar bestuur en overheidsdiensten op basis van flexibele arbeidscontracten wordt gewerkt, terwijl in de landbouw en visserij, de bouwnijverheid en de (detail-)handel juist weinig flexibele arbeidsrelaties voorkomen.

Tabel 6.1

Netto effect van enkele factoren op het percentage schoolverlaters met een flexibele arbeidsrelatie (in procentpunten ten opzichte van het gemiddelde van de referentiegroep)

\section{Verklarende \\ factoren}

flexibele arbeidsrelatie

Bedrijfssector

Landbouw en visserij

Delfstoffen, industrie en nutsbedrijven

Bouwnijverheid

Handel (referentiegroep)

Horeca

Vervoer, opslag en communicatie

Financiële instellingen

Overige zakelijke dienstverlening

Openbaar bestuur en overheidsdiensten

Onderwijs

Gezondheids- en welzijnszorg

Overige kwartaire dienstverlening

Omvang bedrijf

Minder dan 10 werknemers

10 tot 50 werknemers (referentiegroep)

50 tot 500 werknemers

500 werknemers of meer

\section{Woonregio}

Noord

Oost

Zuid

West (referentiegroep)

Buitenland

Geslacht

Mannen (referentiegroep)

Vrouwen

Etniciteit

Autochtonen (referentiegroep)

Allochtonen

$*$ = significant op $5 \%$-niveau 


\section{Bedrijfsgroepen waarin door schoolverlaters het meest op basis van een flexibele arbeidsrelatie wordt gewerkt}

$\begin{array}{lr} & \% \\ \text { Vervaardiging zuivelprodukten } & 71 \\ \text { Openbaar bestuur } & 63 \\ \text { Groothandel machines/apparatuur/toebehoren } & 42 \\ \text { Groothandel overig consumentenartikelen } & 38 \\ \text { Reiniging gebouwen/transportmiddelen ed } & 37\end{array}$

De verwachting is dat schoolverlaters onder slechte arbeidsmarktomstandigheden eerder een baan met weinig zekerheid accepteren dan onder gunstige arbeidsmarktomstandigheden. Het blijkt inderdaad dat naarmate er bij een opleidingsrichting sprake is van een hogere werkloosheid, werkende schoolverlaters vaker een flexibele arbeidsrelatie hebben. Bij een slechtere arbeidsmarktsituatie zijn schoolverlaters blijkbaar eerder bereid om een baan met minder werkzekerheid te aanvaarden. Het effect is echter slechts klein; het huidige percentage flexwerkers zou bijvoorbeeld oplopen van $22 \%$ tot $26 \%$, indien niet de huidige 15\% maar een kwart van de schoolverlaters langer dan 3 maanden werkloos is.

\subsection{Part-time werk}

Omdat Nederland, zoals reeds is aangegeven in paragraaf 6.1, binnen de Europese Unie een bijzondere positie inneemt ten aanzien van deeltijdarbeid, is het hoogst interessant om na te gaan hoe dit bij nieuwkomers op de arbeidsmarkt is gesteld. In figuur 6.4 wordt - voor zowel 1994 als 1995 - van de schoolverlaters die tenminste 12 uur per week betaald werk verrichten het aandeel weergegeven dat minder dan 35 uur per week werkt ${ }^{3}$. Uit de figuur valt op te maken dat de variatie naar schooltype vrij gering is en rondom het totaal-gemiddelde van $29 \%$ ligt. In de gehele beroepshevolking bedraagt dit aandeel $27 \%{ }^{3 *}$, zodat schoolverlaters hierin nauwelijks een bijzondere positie innemen. Schoolverlaters met een opleiding in de dienstverlenende/verzorgende sector vallen echter op, doordat zij verhoudingsgewijs vaak in part-time functics werkzaam zijn. Dit geldt zowel voor het VBO, het MBO-kort als het MBO-tussen en -lang. Ie belangrijkste mutaties ten opzichte van 1994 zijn de aanzienlijke stijging van het aandeel deeltijd-werkenden bij het opleidingscluster VBO economie en de flinke daling van aandeel part-time functies bij het KMBO economie. Het gemiddelde andeel deeltijders is echter tussen 1994 en 1995 vrijwel niet veranderd.

\footnotetext{
37 In dit rapport word normaliter bij werkende schoolverlaters uitgegaan van personen die tenminste 12 uur per week betaald werk verrichten en niet voltijd verder zijn gaan leren. In deze paragraaf zijn bovendien de doorstromers naar het dual onderwijs buitengestoten, omdat aij wedhatast per definitie een lager aantal arbeidsuren hebben 
Vrouwelijke schoolverlaters hebben vaker een part-time baan. Van de mannelijke schoolverlaters werkt gemiddeld 14\% minder dan 35 uur per week; bij de vrouwelijke schoolverlaters bedraagt dit maar liefst 39\%. In uren uitgedrukt werken mannelijke schoolverlaters gemiddeld 38 uur per week, terwijl bij vrouwelijke schoolverlaters het gemiddelde wekelijkse aantal uren op 34 uur ligt. In de gehele beroepsbevolking werkt $9 \%$ van de mannen en $44 \%$ van de vrouwen in een part-time functie ${ }^{39}$. Ofschoon de verhouding bij schoolverlaters iets minder scheef is dan bij de gehele beroepsbevolking, geldt in beide gevallen dat vrouwen veel vaker in deeltijd werken dan mannen. Ook allochtonen werken vaak geen volledige werkweek. Van de autochtone schoolverlaters werkt gemiddeld $28 \%$ part-time, terwijl van de allochtone schoolverlaters $38 \%$ in een deeltijdfunctie werkzaam is. Het effect van geslacht en etniciteit blifft overigens gehandhaafd wanneer rekening wordt gehouden met verschillende factoren, zoals het gevolgde opleidingscluster en de bedrijfssector waarin men werkzaam is. Zie tabel 6.2 voor een overzicht van deze netto effecten op de mate waarin door schoolverlaters in deeltijd wordt gewerkt.

In West-Nederland wordt veel vaker full-time gewerkt dan in de overige regio's in Nederland. Vooral in Noord-Nederland wordt vaak in deeltijd gewerkt. Het regio-effect

Figuur 6.4

Percentage schoolverlaters met een deeltijdaanstelling per opleidingscluster, 1994 en $1995^{*}$

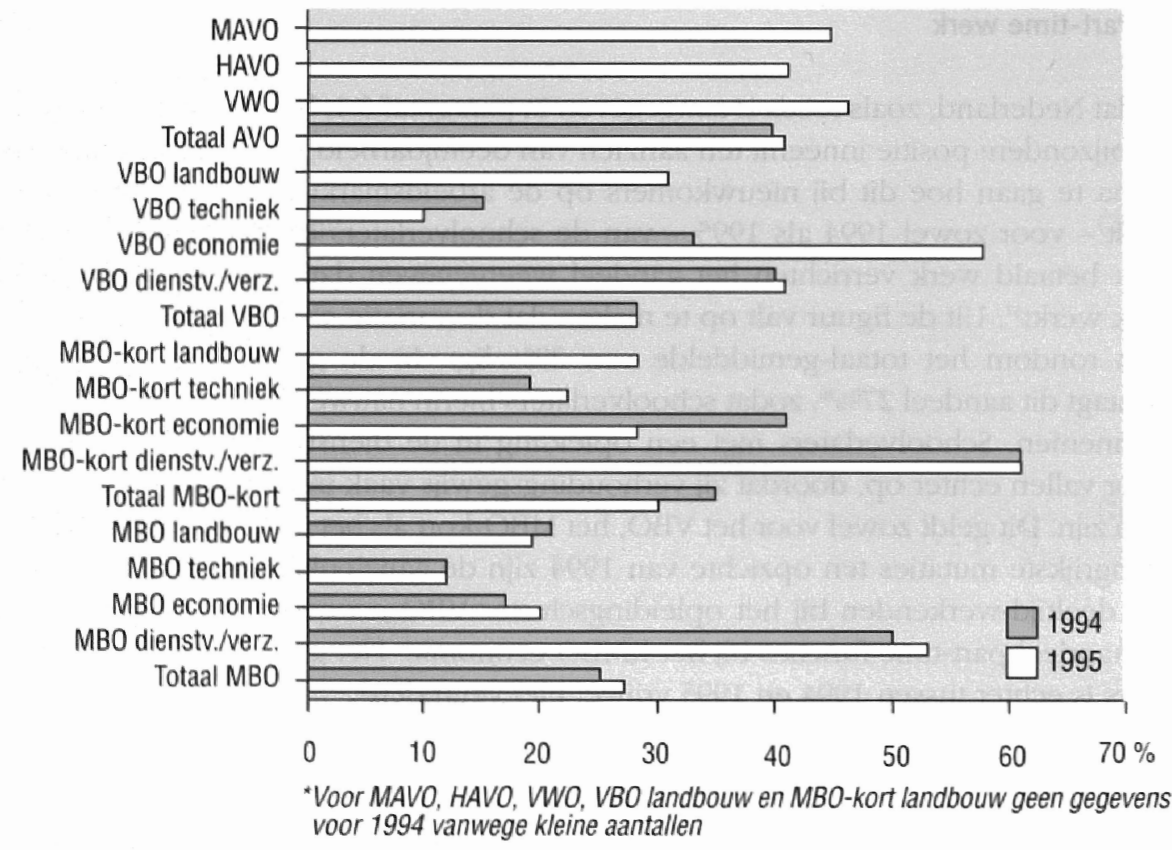

39 Centraal Bureau voor de Statistiek, 1995, op cit. 
Tabel 6.2

Netto effect van enkele factoren op het percentage schoolverlaters met een deeltijdaanstelling (in procentpunten ten opzichte van het gemiddelde van de referentiegroep)

Verklarende

deeltijd-

factoren aanstelling

Bedrijfssector

Landbouw en visserij

Delfstoffen, industrie en nutsbedrijven

Bouwnijverheid

Handel (referentiegroep)

Horeca

Vervoer, opslag en communicatie

Financiële instellingen

Overige zakelijke dienstverlening

Openbaar bestuur en overheidsdiensten

Onderwijs

Gezondheids- en welzijnszorg

Overige kwartaire dienstverlening

Omvang bedrijf

Minder dan 10 werknemers

10 tot 50 werknemers (referentiegroep)

50 tot 500 werknemers

500 werknemers of meer

Woonregio

Noord

Dost

Zuid

West (referentiegroep)

Buitenland

Geslacht

Mannen (referentiegroep)

Vrouwen

\section{Etniciteit}

Autochtonen (referentiegroep)

Allochtonen

* = significant op $5 \%$-niveau

kan te maken hebben met de krappere arbeidsmarktsituatie in het westen van Nederland. Verder speelt tevens de omvang van het bedrijf of instelling een rol. Grote organisaties met meer dan 500 werknemers en ook organisaties met tussen de 50 en de 500 werknemers bieden vaker part-time functies aan dan kleinere organisaties met tussen de 10 en 50 werknemers. Kleinere bedrijven werven schoolverlaters vaker voor fulltime functies. Daarnaast blijkt de bedrijfssector waarin een schoolverlater werk heeft gevonden sterk bepalend te zijn voor het hebben van een part-time functie. In de bouwnijverheid worden bijvoorbeeld bij schoolverlaters niet vaak deeltijdfuncties aangetroffen. Ook bij financiële instellingen en in de industrie is het aandeel deeltijdbanen voor 
schoolverlaters laag. Daarentegen komt in de gezondheids- en welzijnszorg, het onderwijs en de overige kwartaire dienstverlening relatief vaak part-time werk voor. De bedrijfssector handel, waarin een kwart van de schoolverlaters werkzaam is, neemt hierbij een middenpositie in.

\section{Bedrijfsgroepen waarin door schoolverlaters het meest in deeltijd wordt gewerkt}

$\begin{array}{lc} & \% \\ \text { Reiniging gebouwen/transportmiddelen ed } & 79 \\ \text { Welzijnszorg } & 71 \\ \text { Niet-gespecialiseerde detailhandel in winkel } & 62 \\ \text { Gezondheidszorg } & 54 \\ \text { Openbaar bestuur } & 47\end{array}$

\subsection{Mobiliteit bij intrede op de arbeidsmarkt}

Voor veel schoolverlaters is de huidige baan vanzelfsprekend niet de laatste baan. In het eerste jaar na schoolverlaten heeft maar liefst 35\% van de werkenden reeds meer dan één baan gehad. Er is derhalve sprake van een grote baanmobiliteit bij de intrede op de arbeidsmarkt. Opvallend genoeg blijkt een dergelijk percentage voor vrijwel alle onderscheiden opleidingen te gelden. Ook van de HBO-afgestudeerden heeft een aanzienlijk deel in de beginfase van de carrrière reeds meerdere banen gehad ${ }^{* 0}$.

In figuur 6.5 is weergegeven welk gedeelte van de schoolverlaters op zoek is naar een andere baan, waarbij tevens de vergelijkbare gegevens van 1994 zijn opgenomen. Bij VBO-schoolverlaters is deze zogenaamde potentiële mobiliteit duidelijk lager dan bij AVO- en (K)MBO-schoolverlaters. Gemiddeld 10\% van de werkende VBO'ers heeft in de laatste vier weken naar een andere baan gezocht of is in afwachting van de uitkomst van een reeds lopende sollicitatie. Bij de drie overige schooltypen is dit gemiddeld bijna twee maal zoveel. Ten opzichte van 1994 is er bij de meeste opleidingsclusters overigens sprake van een geringe daling van de potentiële mobiliteit. De meest opvallende daler in dit verband is het KMBO techniek, waar de potentile mobiliteit in 1994 nog 21\% bedroeg en in 1995 uitkomt op 12\%. De korte MBO-opleiding economie springt eruit omdit het zowel in 1994 als in 1995 een hoog percentage werkende schoolverlaters kent dat op zoek is naar ander werk. Mogelijk heeft een deel van de schoolverlaters van deze opleiding onder dwang van dreigende werkloosheid een minder aantrekkelijke baan geaccepteerd, maar blift men wel doorzoeken naar een betere baan.

Schoolverlaters die een flexibele arbeidsrelatie hebben of in deeltijd werken zijn verhoudingsgewijs vaak op zoek naar een andere werkkring. Dit wijst er op dat deze schoolverlaters een dergelijke flexibele arbeidsrelatie als onwenselijk ervaren. Tabel 6.3 , watrin de netto effecten van verschillende verklarende factoren op de potentiële

to P.I.E. van de Loo, J. Hoeventerg. R.K.W. van der velden, 1995, op cit. 
Figuur 6.5

Percentage schoolverlaters dat op zoek is naar een andere baan per opleidingscluster, 1994 en 1995*

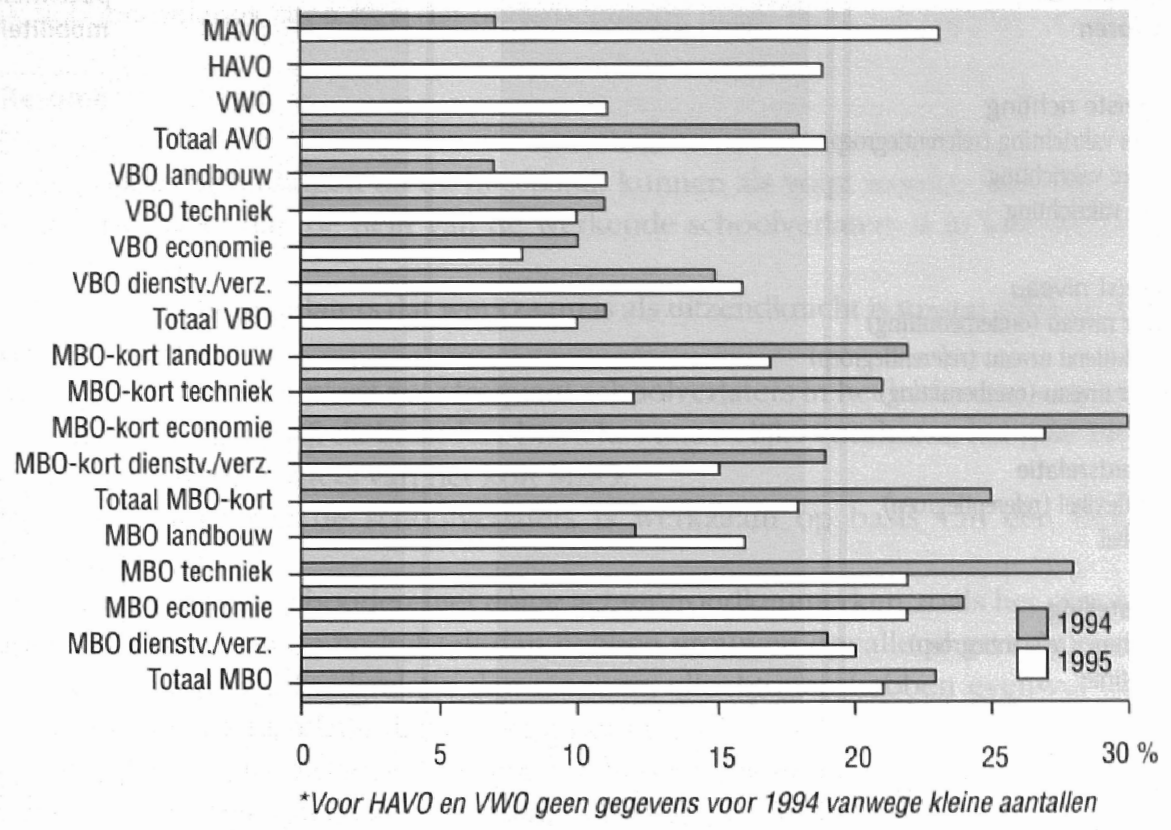

mobiliteit van schoolverlaters zijn gepresenteerd, laat dit zien ${ }^{41}$. Opvallend is verder dat schoolverlaters waarvoor de huidige baan niet de eerste baan is, ook vaker op zoek zijn naar een andere baan. Dit kan er enerzijds op duiden dat ook de huidige baan nog niet tot tevredenheid stemt, maar het kan anderzijds ook een aanwijzing zijn dat het zock-

\section{Bedrijfsgroepen met de hoogste potentiële mobiliteit van schoolverlaters}

Vervaardiging zuivelprodukten

Verzekeringswezen/pensioenfondsen (excl. verplicbte sociale verzekeringen) 44

Openbaar bestuur

Post-/koeriersdiensten

29

Akker-/tuinbouw

41 De netto effecten van bedrijfssector, omvang bedrijf en woonregio zijn nicl gepresentecrel. 1) (\%) blijken alle niet significant van 0 te verschillen.

42 E.W. Mekkelholt, 1993, op cit 
Tabel 6.3

Netto effect van enkele factoren op de potentiële mobiliteit van schoolverlaters (in procentpunten ten opzichte van het gemiddelde van de referentiegroep)

Verklarende

factoren

potentiële

mobiliteit

Vereiste richting

Eigen vakrichting (referentiegroep)

$(13 \%)$

Andere vakrichting

Geen vakrichting

Vereist niveau

Lager niveau (onderbenutting)

$+3^{*}$

Aansluitend niveau (referentiegroep)

Hoger niveau (overbenutting)

Arbeidsrelatie

Niet flexibel (referentiegroep)

Flexibel

Aanstelling

Full-time (referentiegroep)

Part-time

Aantal banen

Eerste baan (referentiegroep)

Niet eerste baan

Geslacht

Mannen (referentiegroep)

Vrouwen

Etniciteit

Autochtonen (referentiegroep)

Allochtonen

* = significant op $5 \%$-niveau

gedrag sterk samenhangt met een persoonseigenschap. In de literatuur wordt in dit verband wel het onderscheid gemaakt tussen 'zoekers' en 'niet-zoekers ${ }^{42}$.

Verwacht mag worden dat schoolverlaters die werkzaam zijn in een baan die qua opleidingsniveau of vakrichting slecht aansluit vaker op zoek zullen gaan naar ander werk. Deze verwachting wordt inderdaad bevestigd in de uitgevoerde analyse. Indien ervan wordt uitgegaan dat zij in hun opzet slagen en een baan vinden die meer aansluit bij hun opleiding, zal de aanvankelijk minder goede kwaliteit van de match tussen de

42 E.W. Mekkelholt, 1993, op cit. 
gevraagde en de aangeboden kwalificaties wellicht in de loop der tijd enigszins verbeteren. De Grip, Heijke en Willems hebben reeds eerder aangetoond dat jongeren nogal eens een baan onder hun niveau accepteren, om later - bijvoorbeeld via de bedrijfsinterne arbeidsmarkt - een hogere functie te verwerven ${ }^{43}$. Ook Groot en Maassen van den Brink hebben onlangs laten zien dat onderbenutting nogal eens van tijdelijke aard is ${ }^{44}$.

\subsection{Resumé}

De belangrijkste bevindingen uit dit hoofdstuk kunnen als volgt worden samengevat:

- Slechts iets meer dan de helft van de werkende schoolverlaters is in loondienst bij een werkgever.

- Het aandeel schoolverlaters dat werkzaam is als uitzendkracht is tussen 1994 en 1995 licht gestegen.

- Het openbaar bestuur werft zeer frequent schoolverlaters in het kader van een werkervaringsproject, terwijl dit in andere branches nauwelijks voorkomt; het gaat hierbij vooral om schoolverlaters van het kort MBO.

- Bijna een kwart van de schoolverlaters is werkzaam op basis van een flexibel arbeidscontract.

- Als rekening wordt gehouden met enige achtergrondkenmerken zoals het gevolgde opleidingscluster en de bedrijfstak dan hebben vrouwen opvallend genoeg minder vaak een flexibele arbeidsrelatie dan mannen; allochtonen hebben evenwel vaker een flexibele arbeidsrelatie dan autochtonen.

- Vrouwelijke en allochtone schoolverlaters hebben vaker een part-time functie dan respectievelijk mannen en autochtonen; in West-Nederland en door kleine bedrijven of instellingen worden relatief vaak full-time banen aangeboden.

- Eén derde van de werkende schoolverlaters heeft binnen een jaar na het verlaten van de opleiding reeds meer dan één functie gehad; één van de vijf schoolverlaters is op zoek naar ander werk.

- Part-time werkende schoolverlaters, schoolverlaters die een flexibel dienstverband hebben en ook schoolverlaters die inmiddels na het verlaten van de opleiding meer dan één baan hebben gehad, zijn vaker op zoek naar een andere baan.

- Schoolverlaters die een baan hebben die qua niveau of richting slecht aansluit bij de gevolgde opleiding zijn eveneens veelvuldiger op zoek naar ander werk.

43 A. de Grip, J.A.M Heijke. E.J.T.A. Willems, 1992, op cil.

44 W. Groot en H. Maassen van den Brink, Overscholing en verdringing op de arbeidsmarkt. Economisch Statistische Bericblen, jrg. 81, nr. 4024, 24 januari 1996, blz. 74-77. 


\section{Additionele training}

\subsection{Inleiding}

Het wordt tegenwoordig alom erkend dat training van werknemers een essentiële rol kan vervullen bij het beter laten functioneren van de economie. Allereerst kan door een dergelijke vergroting van het menselijke kapitaal de produktiviteit worden verhoogd, waardoor bedrijven, branches en landen zichzelf een betere concurrentiepositie kunnen verwerven. Ten tweede fungeert training vaak als de noodzakelijke 'smeerolie' bij de allocatieprocessen op de arbeidsmarkt. Op deze manier kunnen de discrepanties tussen de aangeboden en gevraagde kwalificaties, die het gevolg zijn van bijvoorbeeld technologische en marktontwikkelingen en de daarmee samenhangende ontwikkelingen in de werkgelegenheidsstructuur worden gereduceerd.

Er kunnen verschillende vormen van additionele training worden onderscheiden, variërend van omscholing, die met name is gericht op het bijbrengen van andere kennis en vaardigheden bijvoorbeeld na het veranderen van een baan of wanneer blijkt dat aan de aanwezige kennis te weinig behoefte op de arbeidsmarkt bestaat, bijscholing om de door kennisveroudering verloren gegane vaardigheden te compenseren en de scholing gericht op het inwerken in een nieuwe functie. De laatstgenoemde vorm van training is vooral van belang bij nieuwkomers op de arbeidsmarkt. Door het bestuderen van training bij de intrede op de arbeidsmarkt, komt de feitelijke aansluiting tussen de vereiste kwalificaties op de arbeidsmarkt en de verworven kwalificaties in het onderwijssysteem in beeld. Daarbij speelt onder andere de vraag welke kwalificaties binnen het reguliere onderwijs moeten worden bijgebracht en welke daarbuiten. Recentelijk is gebleken dat het reguliere onderwijs en de training na het schoolverlaten zijn te beschouwen als substituten $^{45}$. Aangezien de functie van training onder meer gelegen is in het compenseren van tekorten in het onderwijs, geeft de mate van deelname aan additionele training door schoolverlaters een goed additioneel inzicht in de kwaliteit van de curricula en de aansluiting van de opleiding op de eisen van de arbeidsmarkt.

Daarnaast worden in dit hoofdstuk enkele specifieke vragen beantwoord. Hoe vaak en op welk terrein volgen werkloze schoolverlaters training, neemt hierbij het Arbeidsbureau vaak de kosten voor zijn rekening en draagt training bij tot het vinden van een baan? Is het zo dat specifieke groepen schoolverlaters die een baan hebben gevonden meteen in secundaire banen terechtkomen die worden gekenmerkt door weinig leermogelijkheden? Volgen schoolverlaters met een flexibele arbeidsrelatic minder vak een cursus of bedrijfsopleiding?

\subsection{Training van werklozen}

In de afgelopen vier jaar is de cursusdeelname van werkloze schoolverlaters opvallend

45 M.S.M. van Smoorenburg en R.K.W. van der Velden, Training of scboolleavers, ROA-RM (verschijnt binnenkort) 
genoeg gestaag afgenomen. In 1992 volgde nog 15\% van de werkloze schoolverlaters een cursus op het moment van enquête en dit aandeel is langzaam aan gedaald tot slechts $7 \%$ in 1995 . Uit figuur 7.1 blijkt dat deze afnemende deelname aan aanvullende scholing door werkloze schoolverlaters zich zowel bij het MBO-tussen en lang, het MBO-kort als het AVO voordoet, maar dat de scholingsparticipatie van werkloze VBOschoolverlaters tussen 1992 en 1995 nagenoeg gelijk is gebleven. Bij werkloze MBO'ers heeft zich recentelijk de daling in scholingsdeelname voltrokken: in 1994 volgden van elke tien werkloze MBO-schoolverlaters er twee een cursus; in 1995 is dit gehalveerd tot één. In 1995 wordt vooral door werkloze schoolverlaters van een korte MBO-opleiding aan een cursus deelgenomen.

Naast deze scholingsdeelname op de onderzoeksdatum, is bovendien gekeken naar de scholingsparticipatie gedurende het eerste jaar na het verlaten van de opleiding. Gemiddeld 20\% van de werkloze schoolverlaters heeft sinds het verlaten van de opleiding een cursus gevolgd. MBO'ers volgen relatief vaak een aanvullende opleiding. Bijna een kwart van de werklozen van zowel het kort $\mathrm{MBO}$ als het MBO-tussen en -lang heeft in het eerste jaar na schoolverlaten reeds een aanvullende opleiding gevolgd. Bij VBOschoolverlaters is het aandeel cursusdeelnemers iets lager, namelijk $18 \%$, en van de werkloze AVO-schoolverlaters heeft $14 \%$ een cursus gevolgd.

Figuur 7.1

Deelname van werkloze schoolverlaters aan een cursus per schooltype, 1992-1995

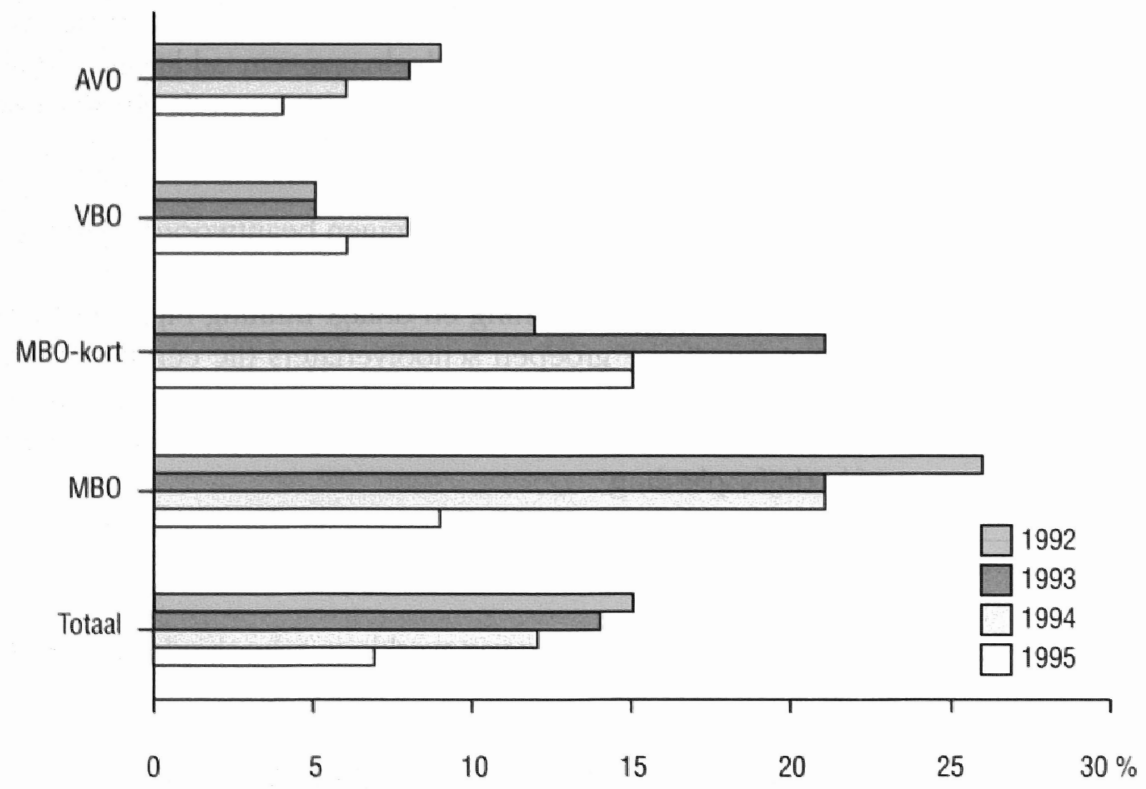


Tabel 7.1

Soort cursus van werkloze schoolverlaters, 1995

Soort cursus

Algemeen vormend, vreemde talen

Techniek

Land- en tuinbouw, veeteelt, bosbouw, milieu

Transport, opslag

(Para)medische vakken, farmacie, verzorging

Maatschappelijk/cultureel werk, personeels- en beroepskeuze

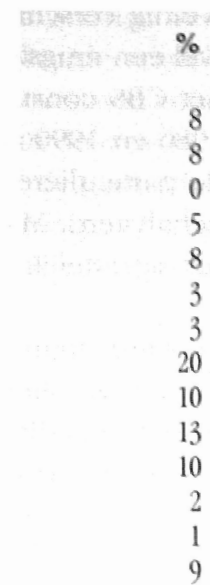

Horeca

Administratie, boekhouden, bedrijfscorrespondentie

Jur. zaken, belastingen, verzekeringen, bankzaken

Automatisering, computergebruik

Management, planning, efficiencyverbetering, organisatiekunde

Marketing, PR, reclame- en verkooptechniek

Sociale vaardigheden, vergadertechniek, onderhandelen

Overig

Totaal $(\mathrm{N}=100 \%)$

Het blijkt dat de helft van de werkloze schoolverlaters een cursus volgt om de kansen op een baan te vergroten. Ook het feit dat twee derde van de werkloze schoolverlaters de cursus zelf betaalt, duidt op een grote motivatie aan de kant van de werkzoekende. Erg opvallend is dat bij slechts 4\% van de werkloze cursisten het Arbeidsbureau de kosten voor haar rekening neemt. Tabel 7.1 geeft tot slot van deze paragraaf een beeld van het soort cursussen dat door de werkloze schoolverlaters wordt gevolgd. Het blijkt dat een groot deel cursussen in de administratieve richting betreft. Het verbaast verder geenszins dat een aanzienlijk deel van de werkloze schoolverlaters een cursus automatisering of computergebruik volgt, daar een zeer groot deel van de schoolverlaters vindt dat hierin in de opleiding te weinig aandacht wordt besteed ${ }^{*}$. Een groot deel van de cursussen die door werkloze schoolverlaters worden gevolgd is behoorlijk intensief. In bijna drie kwart van de gevallen gaat het namelijk om cursussen van 4 maanden of langer, terwijl bovendien gemiddeld zo'n 7 uur per week aan les- en voorbereidingstijd wordt besteed.

\subsection{Training van werkenden}

\section{Deelname aan training}

Evenals bij de werkloze schoolverlaters is ook bij de werkende schoolverlaters de deelname aan training tussen 1992 en 1995 flink gedaald ${ }^{*}$. In 1992 volgde maar liefst ruim $30 \%$ van de werkende schoolverlaters op enquêtedatum een cursus of bedriffsoplei-

\footnotetext{
46 Zie Kerngegevens, tabel 9 en tabel 28.

47 In deze paragraaf worden de schoolverlaters die een opleiding in het kader van het leerlingwe\%en of het in-service onderwijs volgen buiten beschouwing gelaten.
} 
ding; in 1995 is dit aandeel echter vrijwel gehalveerd. Deze dalende trainingsparticipatie doet zich bij alle schooltypen voor, zo toont figuur 7.2. Er is in het algemeen in 1995 weinig verschil in cursusdeelname tussen de onderscheiden schooltypen, ofschoon er wel een enigszins grotere participatie is naarmate het opleidingsniveau toeneemt. Ook het CBS constateert ${ }^{18}$ dat de forse groei in cursusdeelname er duidelijk uit is. Tussen 1986 en 1990 was er sprake van een toename van het aantal gevolgde opleidingen in de particuliere sector met maar liefst 11\%; tussen 1990 en 1993 is de groei ongeveer gehalveerd. Mares laat bovendien zien dat tussen 1993 en 1994 het aantal cursisten in het schriftelijk en het buitenschools mondeling onderwijs flink is gedaald ${ }^{49}$.

De vergelijking met figuur 7.1 laat zien dat werkende schoolverlaters veel vaker additionele scholing volgen dan de werklozen. Dit zou kunnen wijzen op een afbakening tussen enerzijds de insiders (de werkenden) en anderzijds de outsiders (de werklozen) op de arbeidsmarkt. Daarnaast is van belang dat de opleidingskosten van werklozen vooral door hen zelf worden betaald en dat werkende schoolverlaters de kosten van additionele training soms (gedeeltelijk) ten laste kunnen laten komen van de werkgever.

Figuur 7.2

Deelname van werkende schoolverlaters aan een cursus of bedrijfsopleiding per schooltype, 1992 1995

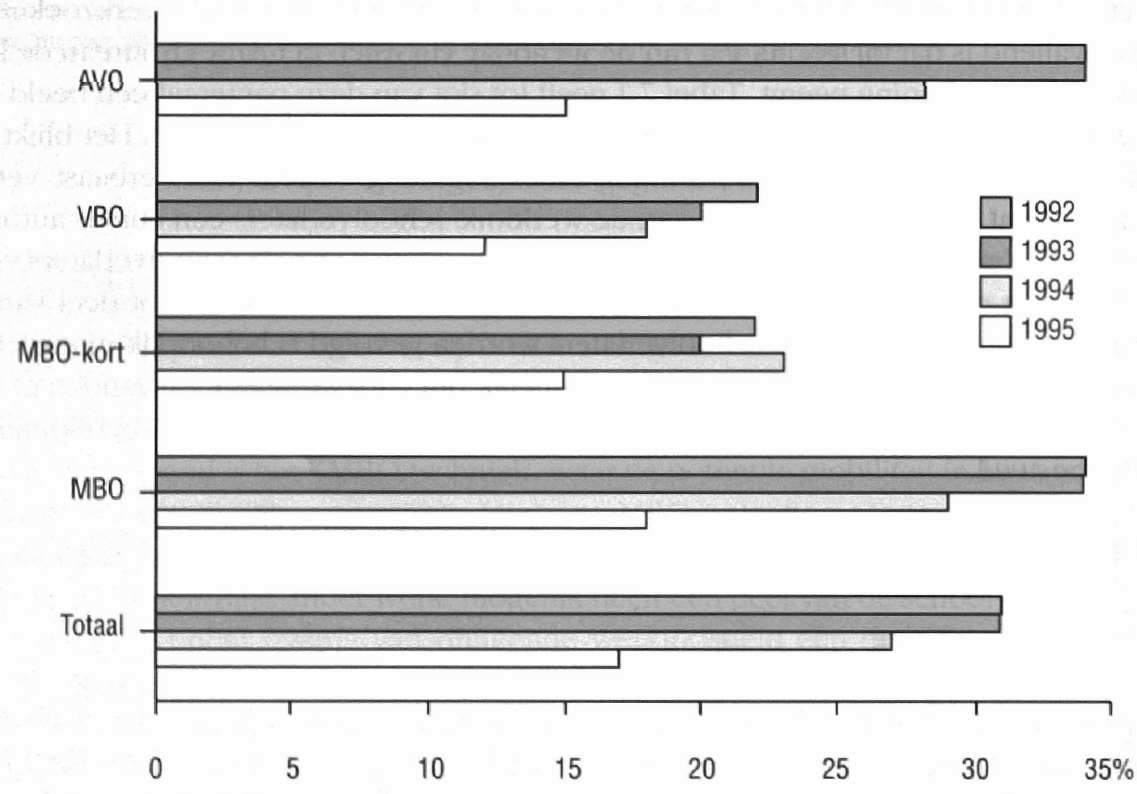

48 Centraal Bureau voor de Statistiek, Bedrijfsopleidingen. Particuliere sector 1993, CBS, Voorburg, 1995.

49 A.M.H.M. Mares, Minder cursisten in het particulier onderwijs, Kuartaalschrift Onderwijsstatistieken, jirg. 2, nr. 2, 1995, blz. 29-31. 
De cursussen en bedrijfsopleidingen die door de schoolverlaters worden gevolgd verschillen in duur en wekelijkse belasting. Tabel 7.2 toont dat het bij werkende schoolverlaters veelal gaat om vrij intensieve training: maar liefst de helft van de cursisten volgt een cursus of bedrijfsopleiding die 4 tot 12 maanden duurt en bij 30\% van de cursisten neemt de aanvullende opleiding zelfs langer dan één jaar in beslag. Ook de gemiddelde wekelijkse studiebelasting is hoog. Veelal gaat het hier om enkele uren per week, maar $12 \%$ van de schoolverlaters besteedt maar liefst meer dan 10 uur per week aan deze aanvullende opleiding.

Tabel 7.2

Duur en wekelijkse belasting van de cursussen of bedrijfsopleiding die door werkende schoolverlaters worden gevolgd, 1995

Duur

1 week of minder 3

van $1 \mathrm{~V} / \mathrm{m} 4$ weken 5

van $2 \mathrm{Vm} 3$ maanden 12

$\operatorname{van} 4 \mathrm{Vm} 12$ maanden 50

langer dan 1 jaar

Wekelijkse les- en voorbereidingstijd

2 uur of minder 18

$3 \mathrm{t} / \mathrm{m} 5$ uur

$6 \mathrm{t} / \mathrm{m} 10$ uur

meer dan 10 uur

Het trainen of werven van personeel door werkgevers zou beschouwd kunnen worden als een 'make-or-buy decision'. Bij hogere trainingskosten zal het vizier gericht zijn op alternatieve, c.q. hogere opleidingscategorieën. Zeker gegeven het feit dat het Nederlandse onderwijsbestel sterk wordt gekarakteriseerd door een grote mate van differentiatie naar zowel opleidingsniveau als vakrichting, zullen werkgevers bij een hoog oplopende trainingsinspanning sneller kiezen voor een ander recruteringsbeleid, in casu het werven van anders of hoger opgeleiden. Een hoge trainingsintensiteit bij bepaalde opleidingsrichtingen zou dan de voorbode kunnen zijn van een toekomstige verslechtering van de arbeidsmarktpositie van de desbetreffende opleiding.

Om een betere vergelijking mogelijk te maken van de intensiteit van de training die door de schoolverlaters van de onderscheiden opleidingen wordt gevolgd, is een samengestelde index berekend ${ }^{50}$. Tabel 7.3 toont de opleidingsrichtingen met respec-

50 Zie Centraal Bureau voor de Statistiek. Bedriffsopleidingen 1990. CBS, Voorburg. 1993. In het soort. gelijke CBS-onderzoek over 1993 is een andere classificatie gebruikt ten aanzien van het soort cursussen of bedrijfsopleidingen. 


\section{Opleidingsrichting}

Hoog

MBO elektrotechniek

MBO uiterlijke verzorging

MBO administratie

MBO bouwkunde

$\mathrm{MBO}$ weg- en waterbouwkunde

MBO overig economie

Laag

MBO-kort verzorging

MBO-kort elektrotechniek

$\mathrm{MBO}$ activiteitenbegeleiding

MBO motorvoertuigentechniek

$\mathrm{MBO}$ verzorging

\section{trainingsintensiteit}

2,47

2,31

2,14

2,03

2,02

2,00

0,00

0,14

0,22

0,24

0,35

Tabel 7.4

Bedrijfsgroepen met hoogste en laagste trainingsintensiteit, 1995

\section{Bedrijfsgroepen}

\section{trainingsintensiteit}

Hoog

Detailhandel farmac./med. art./parfum/cosmetica $\quad 2,83$

$\begin{array}{lr}\text { Overheidsdiensten } & 2,71\end{array}$

$\begin{array}{lr}\text { Openbaar bestuur } & 2,63 \\ & \end{array}$

$\begin{array}{lr}\text { Verzekeringswezen en pensioenfondsen } & 1,79\end{array}$

$\begin{array}{lr}\text { Overige dienstverlening } & 1,68\end{array}$

Laag

$\begin{array}{lr}\text { Fokken of houden van dieren } & 0,05\end{array}$

$\begin{array}{lr}\text { Vervaardiging zuivelprodukten } & 0,16\end{array}$

$\begin{array}{lr}\text { Reklamebureaus e.d. } & 0,20\end{array}$

$\begin{array}{lr}\text { Architecten-, ingenieurs-, teken-, adviesbureaus } & 0,23\end{array}$

$\begin{array}{lr}\text { Welzijnszorg } & 0,33\end{array}$

$\begin{array}{lr}\text { Dienstverlening t.b.v. landbouw (excl. verterinaire dienst) } & 0,33\end{array}$

tievelijk de hoogste en laagste trainingsintensiteit. De trainingsintensiteit bij de lange MBO-opleiding elektrotechniek is ongeveer $2,5 \mathrm{keer}$ zo groot als de gemiddelde trainingsintensiteit van alle opleidingstichtingen. Eén van de vijf schoolverlaters van het $\mathrm{MBO}$ elektrotechniek volgt een cursus of bedrijfsopleiding terwijl deze training bovendien wordt gekenmerkt door een lange duur en een hoge wekelijkse belasting. Erg opvallend is dat de trainingsintensiteit bij de korte MBO-opleiding elektrotechniek juist 
7 keer zo klein is als gemiddeld. Slechts $1 \%$ van de schoolverlaters van deze opleiding volgt additionele scholing. Na afloop van een lange $\mathrm{MBO}$-opleiding elektrotechniek wordt fors geschoold maar na een korte MBO-opleiding elektrotechniek klaarblijkelijk niet. Bij het MBO-kort verzorging is de trainingsintensiteit zelfs nihil, omdat geen enkele van de geënquêteerde werkende schoolverlaters van deze opleiding op dat moment een cursus of bedrijfsopleiding volgt.

Er blijkt eveneens een groot verschil te zijn in de intensiteit van de scholing tussen de verschillende bedrijfssectoren. In tabel 7.4 wordt een overzicht gegeven van de bedrijfsgroepen met respectievelijk de hoogste en de laagste trainingsintensiteit. De overheidsdiensten en het openbaar bestuur worden beide gekenmerkt door een hoge trainingsintensiteit: ruim 2,5 keer zo hoog als gemiddeld. Dit komt met name tot uitdrukking in een verhoudingsgewijs langdurige training van de schoolverlaters in deze sectoren. In zijn algemeenheid kan zelfs worden gesteld dat de non-profit sector wordt gekenmerkt door een gemiddeld lage trainingsdeelname, maar omdat de weinige cursisten in de non-profit sector zulke langdurige cursussen of bedrijfsopleidingen volgen, is de gemiddelde trainingsintensiteit toch hoger dan in de profit-sector.

\section{Doel van de training}

Er zijn vanzelfsprekend verschillende redenen waarom werkenden of bedrijven investeren in aanvullende scholing. Tabel 7.5 geeft een overzicht van de belangrijkste redenen waarom schoolverlaters een cursus of bedrijfsopleiding volgen. Daarbij zijn tevens de vergelijkbare gegevens van 1993 opgenomen. Ruim een kwart van de werkende schoolverlaters ziet in training een mogelijkheid om hogerop te komen. Daarbij moet worden opgemerkt dat mannelijke schoolverlaters dit doel van de training veel vaker noemen dan vrouwelijke schoolverlaters. Van de mannelijke cursisten volgt $35 \%$ de cursus of bedrijfsopleiding om hogerop te komen, terwijl dit bij de vrouwelijke cursisten slechts $22 \%$ is. Verder beschouwt een aanzienlijk deel van de schoolverlaters, het volgen van de cursus of bedrijfsopleiding als noodzakelijk om bij te blijven in de huidige baan. Niet alleen oudere, ervaren werknemers maar dus ook nieuwkomers volgen reeds additionele scholing om bij te blijven in hun functie. Daarbij valt wel op dat dit aandeel in 1995 flink lager ligt dan in 1993. Daarnaast worden door schoolverlaters drie verschillende redenen genoemd die alle betrekking hebben op het nut van training

Tabel 7.5

Reden voor het volgen van een bedrijfsopleiding of cursus van werkende schoolverlaters, 1993 en 1995

Redenen

Bijblijven in huidige baan

Nodig om huidige baan te krijgen

Nodig om hogerop te komen

Met het oog op verkriigen andere baan

Meer kans op ander werk

Andere redenen
1993

1995

$\%$

$29-19$

(1)

$27-27$

$12-9$

$8 \quad 10$

$18 \quad 27$ 
betreffende allocatieprocessen op de arbeidsmarkt. Zo beoogt 10\% van de werkende schoolverlaters met de training de kans op ander werk te vergroten, wil 9\% in een ander soort baan gaan werken en was voor $8 \%$ de cursus of bedrijfsopleiding nodig om de huidige baan te krijgen. Dit betekent dat te zamen ruim een kwart van de schoolverlaters additionele scholing volgt om direct of indirect de kansen op de externe arbeidsmarkt te vergroten.

\section{Soort training}

Het Nederlandse aanbod van cursussen en bedrijfsopleidingen is zeer divers, zowel qua intensiteit als qua inhoud, en dit komt ook in de trainingsgegevens van schoolverlaters tot uitdrukking. De ruim 1100 cursisten volgden maar liefst circa 600 verschillende cursussen of bedrijfsopleidingen. Gemiddeld genomen volgt echter het grootste deel van de werkende schoolverlaters een cursus of bedrijfsopleiding op het terrein van juridische zaken, belastingen, verzekeringen of bankzaken, zo toont tabel 7.6.

Wanneer een verbijzondering wordt gemaakt naar de opleidingssector die de schoolverlaters hebben gevolgd, komen enkele interessante verschillen naar voren. Slechts een kwart van de schoolverlaters van de opleidingssector landbouw volgt na afloop van de studie aanvullende scholing in deze richting. Opvallend vaak volgen schoolverlaters van de landbouwopleidingen een cursus op het gebied van transport of opslag. Technisch opgeleide schoolverlaters volgen uiteraard vaak een aanvullende cursus in deze richting, maar een eveneens belangrijk deel van technisch opgeleide schoolverlaters wordt getraind op het terrein van marketing, public relations, reclame- en ver-

Tabel 7.6

Soort cursus of bedrijfsopleiding van werkende schoolverlaters per opleidingssector, 1995

\section{Soort cursus}

Algemeen vormend, vreemde talen

Techniek

Land- en tuinbouw, veeteelt, bosbouw, milieu

Transport, opslag

(Para)medische vakken, farmacie, verzorging

Matschappelijk/cultureel werk, personeels-

en beroepskeuze

Horeca

Administratie, boekhouden.

bedrijfscorrespondentie

jur. zaken, belastingen, verzekeringen,

bankzaken

Automatisering, computergebruik

Management, planning. efficiencyverbetering, organisatiekunde

Marketing, PR, reclame- en verkooptechniek

Sociale vaardigheden, vergadertechniek,

onderhandelen

Overig

$\begin{array}{rrrrr}\text { landbouw } & \text { techniek } & \text { economie } & \begin{array}{r}\text { dienstverl./ } \\ \text { verzorging }\end{array} & \text { totaal } \\ \% & \% & \% & \% & \%\end{array}$

$\begin{array}{rrrrr}3 & 7 & 6 & 7 & 9 \\ 4 & 30 & 5 & 4 & 11 \\ 26 & 0 & 1 & 0 & 1 \\ 16 & 17 & 2 & 1 & 6 \\ 12 & 1 & 3 & 33 & 8 \\ 0 & 0 & 0 & 2 & 1 \\ 5 & 2 & 6 & 5 & 4 \\ 2 & 5 & 13 & 6 & 9 \\ 10 & 9 & 31 & 6 & 19 \\ 8 & 4 & 4 & 2 & 5 \\ 3 & 6 & 10 & 17 & 10 \\ 4 & 14 & 17 & 9 & 13 \\ 0 & 1 & 1 & 4 & 1 \\ 6 & 4 & 1 & 4 & 2\end{array}$


kooptechniek e.d. Voor hen is kennelijk niet alleen technische kennis van belang voor de uitoefening van de functie. Economisch opgeleide schoolverlaters die aanvullende training volgen doen dit veelal binnen hun eigen vakgebied. De inhoud van de training heeft vaak betrekking op juridische zaken, belastingen of verzekeringen en bankzaken. Eén derde van de schoolverlaters met een dienstverlenende/verzorgende opleiding die nog aanvullend worden geschoold, volgen een cursus of bedriffsopleiding in de (para-) medische vakken, farmacie of verzorging. Ook aanvullende training op het gebied van management, planning, efficiencyverbetering of organisatiekunde komt bij deze opleidingssector echter vaak voor.

Tabel 7.7 maakt een vergelijking van het soort scholing dat schoolverlaters volgen met de aard van de opleidingen die door reeds langer werkenden worden gevolgd. Daarvoor wordt gebruik gemaakt van de resultaten van het CBS-onderzoek naar de deelname aan bedrijfsopleidingen uit 1990". Aangezien dit onderzoek uitsluitend betrekking heeft op de particuliere sector is voor een zo zuiver mogelijke vergelijking bij de schoolverlaters eveneens alleen uitgegaan van diegenen die in de particuliere sector werk hebben gevonden ${ }^{52}$. Heel nadrukkelijk komt naar voren dat door schoolverlaters veel minder vak automatiseringscursussen worden gevolgd dan door degenen die reeds langer werken. Schoolverlaters lijken qua kwalificaties beter te zijn toegerust op

Tabel 7.7

Soort cursus of bedrijfsopleiding van werkende schoolverlaters en beroepsbevolking in de particuliere sector

\section{Soort cursus}

Algemeen vormend, vreemde talen

Techniek

Land- en tuinbouw, veeteelt, bosbouw, milieu

Transport, opslag

(Para)medische vakken, farmacie, verzorging

Maatschappelijk/cultureel werk, personeels- en beroepskeuze

Horeca

Administratie, boekhouden, bedriifscorrespondentie

Jur. zaken, belastingen, verzekeringen, bankzaken

Automatisering, computergebruik

Management, planning, efficiencyverbetering, organisatiekunde

Marketing, PR, reclame- en verkooptechniek

Sociale vaardigheden, vergadertechniek, onderhandelen

Overig

* Bron: CBS (1993)

$\begin{array}{rr}\begin{array}{c}\text { schoolverlaters } \\ \text { particuliere sector }\end{array} & \begin{array}{r}\text { beroepsbevolking } \\ \text { particuliere sector }\end{array} \\ \% & \%\end{array}$

51 Zie Centraal Bureau voor de Statistiek, Bedrijfsopleidingen 1990, CBS, Voorburg, 1993. In het soort gelijke CBS-onderzoek over 1993 is een andere classificatie gebruikt ten aanzien van het soort cursussen of bedrijfsopleidingen.

52 Overigens moet bij deze vergelijking worden bedacht dat de schoolverlaters van het HBO en W() niet in dit onderzoek zijn betrokken terwijl dit bij de beroepsbevolking wel het geval is. 
het gebruik van de computer of wat betreft automatisering dan de overige beroepsbevolking. Als het echter gaat om cursussen of bedrijfsopleidingen op het gebied van juridische zaken, belastingen, verzekeringen of bankzaken geldt echter de omgekeerde conclusie. Schoolverlaters volgen relatief zeer vaak dit soort training. Werkgevers in deze branches hebben kennelijk in onvoldoende mate de mogelijkheid om schoolverlaters te werven die reeds over zodanige kwalificaties beschikken. Daarnaast speelt hier dat de bank- en verzekeringssector bij uitstek kan worden getypeerd als een bedrijfstak met een interne arbeidsmarkt, waarbij het erg gebruikelijk is om bedrijfsspecifieke kennis via formele cursussen op te doen.

\section{Wie wordt getraind?}

Hierboven is reeds aangegeven dat er tussen werkenden en werklozen grote verschillen in scholingsdeelname en -intensiteit bestaan. Tot slot wordt in deze paragraaf de vraag beantwoord of ook bij de werkenden wat dit betreft een onderscheid kan worden gemaakt tussen insiders en outsiders. Tabel 7.8 laat daarvoor het netto effect van verschillende factoren op de trainingsparticipatie van werkenden zien $^{53}$.

Schoolverlaters die op basis van een flexibele arbeidsrelatie werkzaam zijn, volgen minder vaak een cursus of bedrijfsopleiding. Werkgevers zullen bij flexibele arbeidsrelaties twijfels hebben over het te behalen rendement van de investering, terwijl ook werknemers onzeker zijn over de benutting van de nieuwe (bedriffsspecifieke) kwalificaties. Van de schoolverlaters met een min of meer vaste arbeidsrelatie volgt $19 \%$ aanvullende scholing en bij de schoolverlaters met een flexibele arbeidsrelatie is dit slechts $10 \%$. Correctie voor mogelijke overige verklarende factoren, zoals de gevolgde opleiding en de bedrijfssector waarin men werkzaam is, kan het verschil in deelname nauwelijks reduceren: het netto-effect is -8 procentpunten.

Voorts laat de tabel zien dat mannelijke schoolverlaters iets vaker aanvullende training volgen dan vrouwelijke schoolverlaters. Het netto effect bedraagt echter slechts $3 \%$. Allochtone schoolverlaters nemen bovendien vrijwel net zo vaak deel aan een cursus of bedriffsopleiding dan autochtone schoolverlaters. De bewering dat vrouwen en allochtonen reeds bij intrede op de arbeidsmarkt zouden zijn aangewezen op mindere banen van een lagere kwaliteit, waarbij speciaal gewezen wordt op de mogelijkheid tot trainingsparticipatie, wordt - althans in deze analyse - niet bevestigd.

Vooral schoolverlaters van een VBO of (K)MBO-opleiding in de economische richting volgen verhoudingsgewijs vaak een cursus of bedrijfsopleiding. Mogelijk zijn er bij economisch opgeleide schoolverlaters leemtes in het curriculum aanwezig, waardoor bij de intrede op de arbeidsmarkt aanvullende kwalificaties moeten worden opgedaan. Om dit vermoeden te testen is gekeken naar de mening van de schoolverlaters over een aantal aspecten van het curriculum. Daarbij is een vergelijking gemaakt tussen de schoolverlaters van de opleidingssector economie versus de anderszins opgeleide schoolverlaters. Van de in totaal 20 onderzochte aspecten van het curriculum is er bij 11 aspecten geen significant verschil tussen beide categorieën schoolverlaters geconsta-

53 Zie voor een toelichting op de berekening van deze effecten het gele kader op bladzijde 24. 
Tabel 7.8

Netto effect van enkele factoren op de deelname aan een cursus of bedrijfsopleiding door werkende schoolverlaters (in procentpunten ten opzichte van het gemiddelde in de referentiegroep)

Verklarende

factoren

cursus of bedrijfsopleiding

Opleidingscluster

MAVO

HAVO

WWO

VBO landbouw

VBO techniek

VBO economie

VBO dienstverlening/verzorging

MBO-kort landbouw

MBO-kort techniek

MBO-kort economie

MBO-kort dienstverlening/verzorging

MBO landbouw

MBO techniek (referentiegroep)

MBO economie

$\mathrm{MBO}$ dienstverlening/verzorging

Vereiste richting

Eigen vakrichting (referentiegroep)

Andere vakrichting

Geen vakrichting

Vereist niveau

Lager niveau (onderbenutting)

Arbeidsrelatie

Flexibel

Niet flexibel (referentiegroep)

Geslacht

Mannen (referentiegroep)

Vrouwen

Etniciteit

Autochtonen

Allochtonen

* = significant op $5 \%$ niveau

teerd en aan 2 aspecten (i.c. 'vakkennis' en 'gebruik van apparatuur') hoeft volgens de' economisch opgeleiden minder aandacht te worden besteed. Daar staat tegenover dat voor maar liefst 7 elementen van het curriculum door de economisch opgeleiden meer aandacht wordt gewenst. Deze aspecten zijn: 'correcte spelling', 'spreekvaardighcid', 'met cijfers werken', 'informatica/automatisering', 'commerciële kennis/verkooptechniek', 'leren solliciteren' en tot slot 'omgaan met klanten/patiënten e.d.'. 
Hierboven is reeds geconstateerd dat in de ene bedrijfssector de trainingsintensiteit beduidend groter is dan in de andere. Ook als wordt gecorrigeerd voor andere factoren blijkt er een flinke variatie in de trainingsdeelname tussen de bedrijfssectoren te bestaan $^{54}$. Schoolverlaters die bij een financiële instelling werken volgen namelijk vaak een cursus of bedrijfsopleiding, terwijl bij schoolverlaters die werkzaam zijn in de gezondheids-/welzijnszorg of in de horeca de deelname tamelijk laag is. Opvallend genoeg is de organisatiegrootte niet bepalend voor de deelname aan aanvullende training voor schoolverlaters.

De aansluiting naar opleidingsniveau en vakrichting tussen de vereiste en de aangeboden kwalificaties is eveneens een belangrijke factor voor de participatie aan een cursus of bedrijfsopleiding. Schoolverlaters die in een baan terechtkomen waarvoor een andere dan de eigen vakrichting werd vereist blijken namelijk meer behoefte te hebben aan aanvullende training. Ook diegenen die eigenlijk te laag geschoold zijn voor de functie die ze uitoefenen, volgen veel vaker een cursus of bedrijfsopleiding. De (vaker voorkomende) tegenovergestelde situatie, waarbij schoolverlaters een baan onder hun eigen opleidingsniveau hebben aanvaard, leidt tot een iets geringere deelname aan een cursus of bedriffsopleiding. Een surplus of een manco in kwalificaties leidt derhalve tot respectievelijk een kleinere en grotere trainingsbehoefte in het begin van de loopbaan. Dit impliceert dat het reguliere onderwijs en additionele training zijn te beschouwen als een stelsel van 'communicerende vaten': tekorten aan kwalificaties worden middels training weggewerkt, terwijl overschotten juist tot een geringere trainingsbehoefte leiden. Eerder onderzoek heeft laten zien dat dit mechanisme eveneens van toepassing is als de breedte van de opleiding in ogenschouw wordt genomen ${ }^{55}$. Smallere opleidingen, die specifiek gericht zijn op een of enkele beroepen of branches, leiden tot minder behoefte aan aanvullende training voor zover schoolverlaters in de eigen richting terechtkomen en juist tot meer training indien moet worden uitgeweken naar een alternatief segment op de arbeidsmarkt. Kwalificatietekorten worden derhalve met name gecompenseerd voor diegenen die hetzij een aansluitende, bredere opleiding achter de rug hebben, hetzij een niet-aansluitende, smalle opleiding.

Bij dit mechanisme van wisselwerking tussen initieel en additioneel onderwijs kan echter de volgende kanttekening worden geplaatst. Vanzelfsprekend zullen niet alle schoolverlaters - eventueel te zamen met werkgevers - de aanwezige deficieten wegwerken en zullen slechts de best renderende trainingsinvesteringen, doorgaan. De overheid kan dus niet zonder meer op het post-initieel onderwijs vertrouwen, onder het motto dat tekortkomingen in de curricula toch wel door de markt worden opgelost. verder kan er in dit verband op worden gewezen dat de hogere trainingsdeelname van schoolverlaters met een (aansluitende) bredere opleiding voor een deel wordt gecompenseerd door een lager aanvangssalaris. Het blijkt dat schoolverlaters van meer beroeps- of branchespecifieke opleidingen, die hun kwalificaties direct in het begin van hun loopbaan op de arbeidsmarkt kunnen inzetten, meer verdienen ${ }^{6}$. Degenen die

54 Vanwege de overzichtelijkheid zijn de resultaten voor de verschillende bedriffsectoren niet expliciet in tabel 7.8 weergegeven.

55 M.S.M. van Smoorenburg en R.K.W. van der Velden, 1996, op cit. 
meer algemeen zijn opgeleid zijn echter in het voordeel, zodra moet worden uitgeweken naar andere segmenten van de arbeidsmarkt. Zij hoeven dan minder extra geschoold te worden dan specifiek opgeleiden. In zijn algemeenheid kan derhalve worden gesteld dat meer generalistisch opgeleiden flexibler op de arbeidsmarkt zijn, waardoor - zeker op langere termijn - hun kwalificaties wellicht beter kunnen worden benut.

\subsection{Resumé}

- De trainingsdeelname is zowel bij werkloze als bij werkende schoolverlaters tussen 1992 en 1995 sterk gedaald; bij de werklozen betreft dit een afname van 15\% tot 7\%, terwijl bij de werkenden de cursusdeelname is afgenomen van 30\% tot $17 \%$.

- Werkloze schoolverlaters volgen minder vaak en ook minder langdurige cursussen dan werkende schoolverlaters.

- Een groot deel van de werkloze schoolverlaters neemt zelf de kosten voor zijn rekening; slechts bij een zeer gering gedeelte van de werklozen worden de cursuskosten door het Arbeidsbureau vergoed.

- Etniciteit en geslacht spelen slechts een marginale rol in het verschil de deelname aan aanvullende training.

- De reden voor het volgen van een cursus of bedrijfsopleiding verschilt wel tussen mannen en vrouwen: mannen willen de scholing vaker gebruiken om hogerop te komen.

- Schoolverlaters met een min of meer vaste arbeidsrelatie volgen bijna twee keer zo vaak een cursus of bedrijfsopleiding dan schoolverlaters met een flexibele arbeidsrelatie.

- Nieuwkomers op de arbeidsmarkt worden in vergelijking met de rest van de beroepsbevolking relatief vaak getraind op het terrein van juridische zaken, belastingen, verzekeringen, bankzaken en volgen in vergelijking tot de reeds langer werkenden relatief weinig cursussen op het terrein van de automatisering en het gebruik van computers.

- Het initiële onderwijs en de training van schoolverlaters zijn voor een deel te beschouwen als substituten: onderschoolden worden vaker getraind terwijl degenen die in hun kwalificaties worden onderbenut juist iets minder vaak een aanvullende cursus volgen; daarnaast levert uitwijking naar een alternatief segment op de arbeidsmarkt een grotere scholingsnoodzaak op en worden breder opgeleiden vaker geschoold als ze in de eigen vakrichting terechtkomen en juist minder valk als ze moeten uitwijken natr een baan waarvoor een andere vakrichting is vereist.

56 M.S.M. van Smoorenburg en R.K.W. van der velden, 1995, op cit 
Schooviveriaters dus 


\section{Enkele centrale begrippen}

\section{Allochtoon}

Iemand die zichzelf niet tot de Nederlandse bevolkingsgroep rekent.

\section{Beroep}

Alle beroepen zijn ingedeeld volgens de Standaard Beroepenclassificatie 1992 van het CBS. In dit rapport wordt met name uitgegaan van de indeling in 121 beroepsgroepen.

\section{Beroepsbevolking}

Tot de beroepsbevolking behoren degenen die:

- ten minste 12 uur per week werken;

- werk hebben aanvaard waardoor zij ten minste 12 uur per week gaan werken;

- ten minste 12 uur per week willen werken, daardoor beschikbaar zijn en daartoe tevens activiteiten ontplooien.

In deze rapportage wordt daartoe tevens als voorwaarde gesteld dat het moet gaan om schoolverlaters die niet doorstromen naar he voltijd dagonderwijs.

Publikatie:

Centraal Bureau voor de Statistiek, Enquête Beroepsbevolking 1994, Voorburg/Heerlen, 1995 .

\section{Bedrijfssector}

Alle bedrijven zijn ingedeeld volgens de Standaard Bedrijfsindeling 1993 van het CBS. In dit rapport wordt met name uitgegaan van de indeling in 211 bedrijfsgroepen.

\section{Bruto loon}

Het bruto maandloon heeft betrekking op de baan waarin men het meeste aantal uren werkt, inclusief toeslagen voor ploegendienst of fooien, maar exclusief vakantiegeld, inkomen uit overwerk of inkomen op basis van een uitkering. Het bruto uurloon is gelijk aan het bruto maandloon, gedeeld door het contractuele aantal arbeidsuren in de baan waarin men de meeste uren werkt, vermenigvulgdigd met de factor 12/52.

\section{Conjuncturgevoeligheid}

De conjunctuurgevoeligheid van de werkgelegenheid geeft aan in welke mate de werkgelegenheid voor mensen met een bepaalde opleiding gevoelig is voor veranderingen van de economische situatie. De conjunctuurgevoeligheid wordt bepald door de sectorale werkgelegenheidsfluctuaties in het verleden te relateren aan de mate waarin ecn opleiding in de verschillende bedrijfssectoren is vertegenwoordigd.

\section{Flexibele arbeidsrelatie}

Van een flexibele arbeidsrelatie is sprake bij uitzendwerk, een oproep- of nulurencon- 
tract, een werkervaringsproject of indien men in loondienst is bij een werkgever of op basis van leer-werk-overeenkomst werkzaam is met een contract van maximaal een half jaar.

\section{Intredewerkloosheid}

Het aantal maanden dat schoolverlaters aangeven in totaal werkloos te zijn geweest sinds het verlaten van de opleiding.

\section{Onderbenutting}

Van onderbenutting is sprake als het opleidingsniveau dat minimaal vereist is voor de functie lager is dan het feitelijke onderwijsniveau.

\section{Opleiding}

Alle opleidingen zijn ingedeeld volgens een daarvoor speciaal ontworpen classificatie. In dit rapport wordt onderscheid gemaakt tussen vier schooltypen (AVO, VBO, MBOkort en MBO-tussen en -lang), 18 opleidingsclusters (bijvoorbeeld VBO techniek) en 69 opleidingsrichtingen (bijvoorbeeld VBO elektrotechniek).

\section{Uitwijkmogelijkheden}

De mate waarin men met een bepaalde opleiding terecht kan komen in andere bedrijfsof beroepsgroepen. Daarvoor wordt gebruik gemaakt van de bedriifs- en beroepsgroepenspreiding die worden bepaald aan de hand van de Gini-Hirschman coëfficiënt. Deze index is gelijk aan 0 indien er een volledige concentratie van de werkenden in één bedrijfsgroep, respectievelijk beroepsgroep is en gelijk aan 1 indien de werkenden juist precies gelijk verdeeld zijn over alle bedrijfs- of beroepsgroepen.

\section{Werkende}

lemand die ten minste 12 uur per week betaald werk verricht. In deze rapportage wordt daarbij tevens als voorwaarde gesteld dat het moet gaan om schoolverlaters die niet doorstromen naar het voltijd dagonderwijs.

\section{Werkloosheid}

In deze rapportage wordt uitgegaan van de Geregistreerde werkloosheid confrom CBSdefinitie, dat wil zeggen:

- ingeschreven bij een arbeidsbureau;

- niet of minder dan 12 uur per week werken:

- beschikbaar zijn voor een baan voor 12 uur of meer per week of werk hebben aanvalard waardoor men ten minste 12 uur per week gaat werken.

De werkloosheid wordt gerelateerd aan het aantal schoolverlaters dat tot de beroepsbevolking behoort en niet doorstroomt naar het voltijd dagonderwijs.

Publikatie:

Centraal Bureau voor de Statistiek, Enquête Beroepsbevolking 1994, Voorburg/Heerlen. 1995. 